FLAVIA RUPOLO BERACH

\title{
Rede viva: a realidade da Rede de Atenção à Reabilitação na região do Butantã, São Paulo - SP
}

Dissertação apresentada a Faculdade de Medicina da Universidade de São Paulo para obtenção do título de Mestre em Ciências

Programa de Ciências da Reabilitação

Orientadora: Profa Dra Ana Carolina Basso Schmitt

\section{São Paulo}

2018 


\section{Dados Internacionais de Catalogaçăo na Publicação (CIP)}

Preparada pela Biblioteca da

Faculdade de Medicina da Universidade de Săo Paulo

C)reproduçăo autorizada pelo autor

Berach, Flávia Rupolo

Rede viva : a realidade da rede de atençăo à

reabilitaçăo na regiảo do Butantã, Săo Paulo - SP /

Flávia Rupolo Berach. -- São Paulo, 2018.

Dissertação (mestrado)--Faculdade de Medicina da

Universidade de São Paulo.

Programa de Ciências da Reabilitação.

Orientadora: Ana Carolina Basso Schmitt.

Descritores: 1. Reabilitaçăo 2.Assistência à saúde 3.Acesso aos serviços de saúde 4. Necessidades e demandas de serviços de saúde 5. Atençăo primária à saúde 6.Assistência ambulatorial

$\mathrm{USP} / \mathrm{FM} / \mathrm{DBD}-480 / 18$

Responsável: Erinalva da Conceiçăo Batista, CRB-8 6755 


\section{Agradecimentos}

Agradeço à querida Professora Ana Carolina Basso Schmitt, minha orientadora de mestrado, pela dedicação, competência, apoio e incentivo para encarar o desafio da pós-graduação. Obrigada pela convivência diária e por tantas trocas pessoais e profissionais.

À nossa equipe de projeto: Bárbara, Mariana, Ralf e Paula pela construção conjunta.

Aos professores de tantas Faculdades da Universidade de São Paulo pelo compartilhamento dos saberes e pela busca eterna de novos conhecimentos.

Aos funcionários do Programa de Pós-graduação em Ciências da Reabilitação pelo apoio e paciência.

Aos alunos do curso de Fisioterapia da FMUSP por viverem comigo minhas primeiras experiências no processo ensino-aprendizagem, pelas trocas, pela competência e por me mostrarem as alegrias e responsabilidades de participar dos processos de formação profissional.

À Supervisão Técnica de Saúde do Butantã e à Coordenadoria Regional de Saúde Oeste do município de São Paulo pelo interesse e apoio ao projeto.

Aos equipamentos de saúde pela disponibilidade, entusiasmo e interesse em abrir suas portas para nosso estudo.

Aos profissionais de saúde pela grande contribuição e abertura para a reflexão de suas práticas diárias.

Às usuárias e suas famílias por compartilharem duas experiências e reflexões de forma tão mobilizadora e cheia de afeto.

À minha mãe e irmã pelo amor incondicional e diário.

Aos meus amigos e companheira de vida pela paciência, motivação, carinho e suporte. 
"A alegria não chega apenas no encontro do achado, mas faz parte do processo de busca. E ensinar e aprender não pode dar-se fora da procura, fora da boniteza e da alegria."

"O mundo não é, o mundo está sendo."

(Paulo Freire) 
Esta dissertação está de acordo com as seguintes normas, em vigor no momento desta publicação:

Referências: adaptado de International Committee of Medical Journals Editors (Vancouver).

Universidade de São Paulo. Faculdade de Medicina. Divisão de Biblioteca e Documentação. Guia de apresentação de dissertações, teses e monografias. Elaborado por Anneliese Carneiro da Cunha, Maria Julia de A. L. Freddi, Maria F. Crestana, Marinalva de Souza Aragão, Suely Campos Cardoso, Valéria Vilhena. 3a ed. São Paulo: Divisão de Biblioteca e Documentação; 2011.

Abreviaturas dos títulos dos periódicos de acordo com List of Journals Indexed in Index Medicus. 


\section{SUMÁRIO}

LISTA DE ABREVIATURAS E SIGLAS

LISTA DE QUADROS

LISTA DE FIGURAS

LISTA DE TABELAS

RESUMO

ABSTRACT

APRESENTAÇÃO

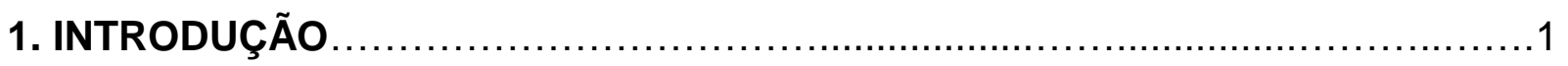

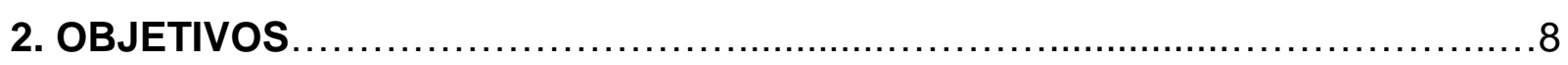

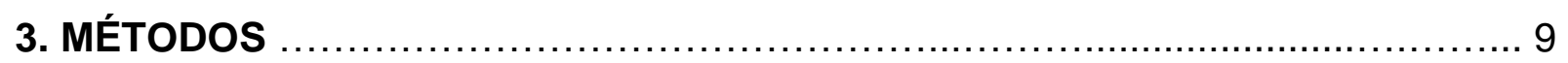

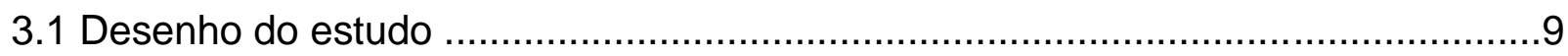

3.2 Local e População de estudo e Amostra ..................................................... 9

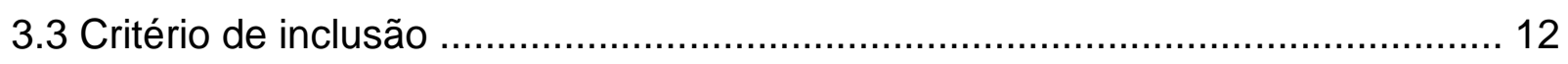

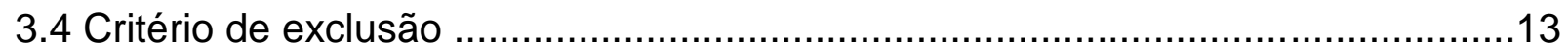

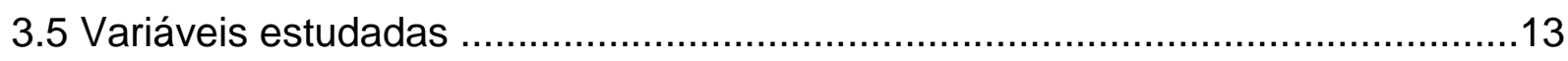

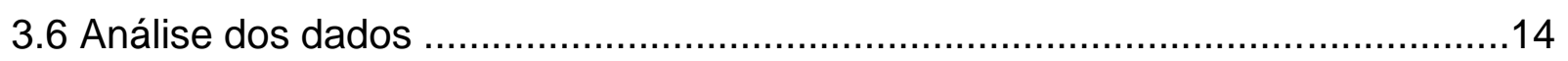

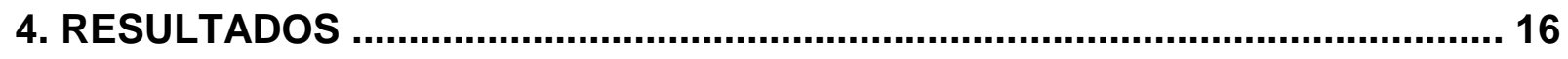

4.1 Fluxos da Rede de Atenção à Reabilitação ...................................................16

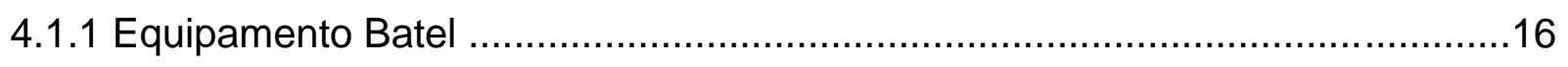

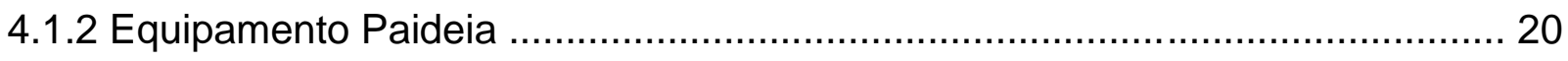

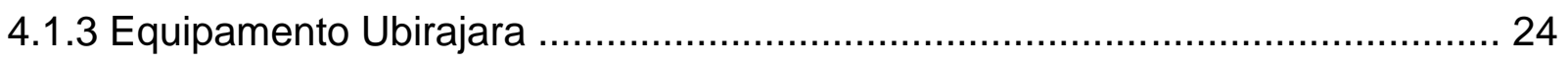

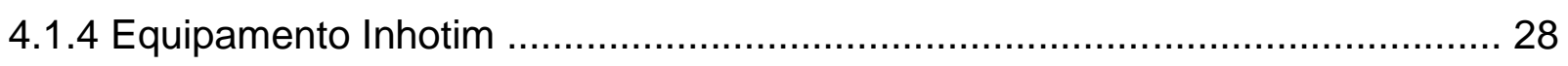

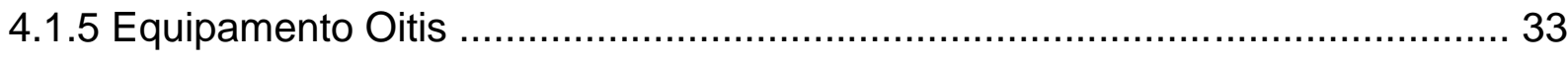

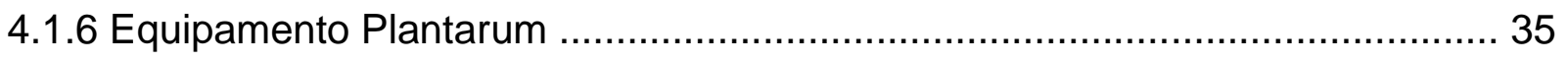

4.2 Trajetória de cuidado de usuários da Rede de Atenção à Reabilitação............... 38

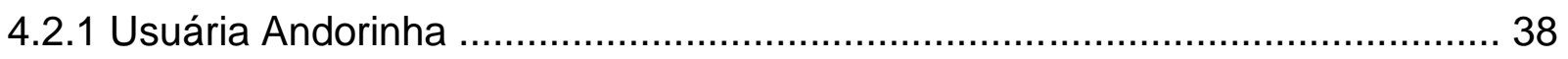




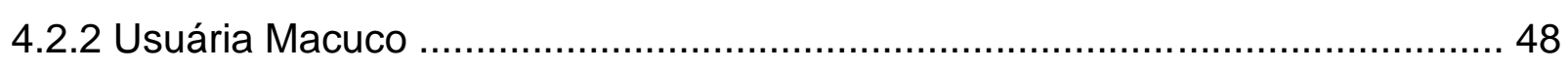

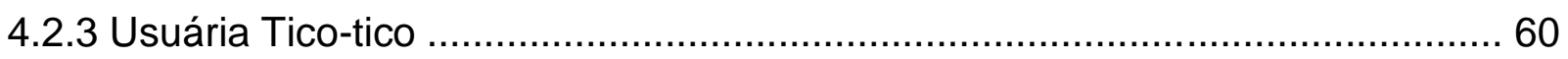

4.3 Demandas de reabilitação atendidas e reprimidas para a atenção especializada

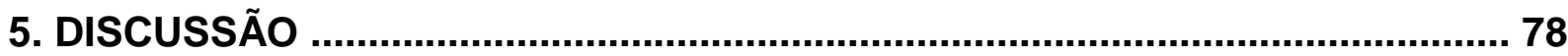

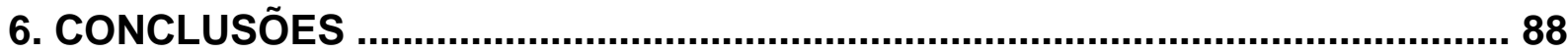

7. REFERÊNCIAS BIBLIOGRÁFICAS .................................................. 90

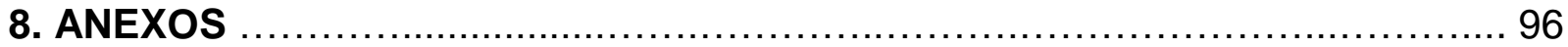

8.1 Apêndice 1 - Autorização para a realização da pesquisa ............................... 96

8.2 Apêndice 2 - Termo de Consentimento Livre e Esclarecido ..............................101

8.3 Apêndice 3 - Roteiro para facilitação dos Grupos de Discussão ....................... 106

8.4 Apêndice 4 - Termo de Consentimento Livre e Esclarecido - usuários ............. 108

8.5 Apêndice 5 - Dados coletados no sistema E-SUS ........................................ 113 


\section{LISTA DE ABREVIATURAS E SIGLAS}

a - anos

ACS - Agente Comunitário de Saúde

AE - Atenção Especializada

$\mathrm{AH}$ - Atenção Hospitalar

AIDS - Síndrome da Imunodeficiência adquirida

APS - Atenção Primária à Saúde

Av - avaliação

AVC - Acidente vascular cerebral

AVE - Acidente Vascular Encefálico

CID-10 - Capítulo da Classificação Estatística Internacional de Doenças e

Problemas Relacionados com a Saúde - décima edição

CR - cadeira de rodas

Def - deficiência

Diag - diagnóstico

DNPM - Desenvolvimento Neuropsicomotor

DST - Doenças sexualmente transmissíveis

ELA - Esclerose lateral amiotrófica

enc - encaminhamento

fisio - fisioterapia ou fisioterapeuta

fono - fonoaudiologia ou fonoaudiólogo

$\mathrm{GO}$ - ginecologista e obstetra

m - meses

NASF-AB - Núcleos Ampliados de Saúde da Família e Atenção Básica

OPM - Órteses, Próteses e Meios Auxiliares de Locomoção

PTS - Projeto Terapêutico Singular

psico - psicologia ou psicólogo

TO - terapia ocupacional ou terapeuta ocupacional

UBS - Unidade Básica de Saúde 


\section{LISTA DE QUADROS}

Quadro 1 - Apresentação das siglas e abreviaturas utilizadas nos fluxogramas para indicar ações, acometimentos de saúde, atividades e categorias

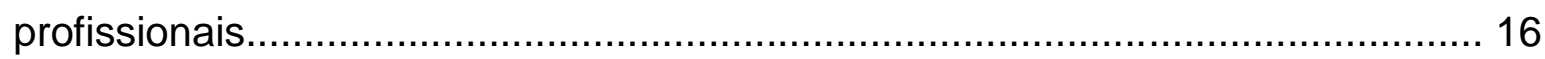




\section{LISTA DE FIGURAS}

Figura 1 - Fluxograma das ações e atividades de reabilitação do equipamento Batel, 2017

Figura 2 - Fluxograma das ações e atividades de reabilitação do equipamento Paideia, 2017. 23

Figura 3 - Fluxograma das ações e atividades de reabilitação do equipamento Ubirajara, 2017. 27

Figura 4 - Fluxograma das ações e atividades de reabilitação do equipamento Inhotim, 2017. 32

Figura 5 - Fluxograma das ações e atividades de reabilitação do equipamento Oitis, 2017.

Figura 6 - Fluxograma das ações e atividades de reabilitação do equipamento Plantarum, 2017. 37

Figura 7 - Linha do tempo da trajetória de cuidado da usuária Andorinha, 2018. 41

Figura 8 - Fluxograma da trajetória de cuidado da usuária Andorinha, 2018...... 43 Figura 9 - Linha do tempo da trajetória de cuidado da usuária Macuco, 2018.... 53 Figura 10 - Fluxograma da trajetória de cuidado da usuária Macuco, 2018........ 55 Figura 11 - Linha do tempo da trajetória de cuidado da usuária Tico-tico, 2018 64

Figura 12 - Fluxograma da trajetória de cuidado da usuária Tico-tico, 2018........ 65 Figura 13: Fluxo de encaminhamentos de demandas de reabilitação da APS para atenção especializada, 2012 a 2016. 72 


\section{LISTA DE TABELAS}

Tabela 1 - Distribuição dos encaminhamentos com demanda de reabilitação para a atenção especializada, 2012 a 2016 ........................................................... 73 


\section{RESUMO}

BERACH FR. Rede viva: a realidade da Rede de Atenção à Reabilitação na região do Butantã, São Paulo - SP [dissertação]. São Paulo: Faculdade de Medicina, Universidade de São Paulo; 2018.

A implantação de políticas e programas para atender as pessoas com incapacidades e deficiências nos diferentes níveis da atenção à saúde continua desafiadora. $\mathrm{O}$ acesso a serviços de reabilitação nos equipamentos de saúde é limitado, assim como o uso das ações de cuidado em reabilitação e há dificuldades de articulação entre os equipamentos da Rede de Reabilitação. O objetivo deste estudo foi compreender a gestão do cuidado; identificar e analisar os fluxos relacionados à reabilitação nos equipamentos de saúde. O estudo foi desenvolvido na região do Butantã (São Paulo - SP), com população de 428.217 habitantes e buscou analisar as ações e fluxos relacionados à reabilitação dos equipamentos de saúde através de rodas de discussão com profissionais de seis equipamentos da Atenção Primária à Saúde e de Atenção Especializada, e de três entrevistas com usuários. Participaram das rodas de discussão 57 profissionais de diferentes categorias que elaboraram fluxogramas que posteriormente foram sobrepostos aos que representam as trajetórias dos usuários. Além disso foi realizada a análise do fluxo de encaminhamentos de demandas de reabilitação da Atenção Primária à Saúde para a Atenção Especializada no período de 2012 a 2016. Os relatos fizeram emergir reflexões sobre abordagens coletivas como ferramenta de cuidado em reabilitação; o papel e resolutividade da Atenção Especializada para o cuidado a longo prazo e queixas menos comuns; o olhar ampliado dos profissionais; o acesso às ações de cuidado, tendo em vista os grandes deslocamentos e o tempo de espera para inclusão; as redes informais como facilitadores do acesso a recursos tecnológicos; e as dificuldades de articulação da Rede. A média das idades dos usuários que aguardavam na lista de espera durante o período de 2012 a 2016 foi de 47,1 anos (DP $=22,5$ ) e a mediana de 51 anos (idade mínima $=0$ anos; idade máxima $=102$ anos). Foram 
analisados 44.022 encaminhamentos de pessoas que residiam, majoritariamente no município de São Paulo (98,95\%). As maiores demandas de encaminhamento para as especialidades encontradas foram para ortopedia $(37,92 \%)$, fisioterapia $(21,47 \%)$, pneumologia $(13 \%)$, neurologia $(9,22 \%)$, psiquiatria $(5,79 \%)$ e acupuntura (3,58\%). A facilitação do acesso às ações e atividades de reabilitação, bem como a articulação da rede de reabilitação e o reconhecimento de seus fluxos, podem potencializar o processo de reabilitação aumentando a resolutividade do cuidado.

Descritores: reabilitação; assistência à saúde; acesso aos serviços de saúde; necessidades e demandas de serviços de saúde; atenção primária à saúde; assistência ambulatorial. 


\section{ABSTRACT}

BERACH FR. Active network: the reality of the Network for Rehabilitation Care in the region of Butantã, São Paulo - SP [dissertation]. São Paulo: "Faculdade de Medicina, Universidade de São Paulo"; 2018.

The implementation of policies and programs to care of people with disabilities at different levels of health care remains challenging. Access to rehabilitation services in health facilities is limited, as is the use of care actions in rehabilitation and there are difficulties of articulation between the equipment of the Rehabilitation Network. The objective of this study was to understand the management of care; identify and analyze the flows related to rehabilitation in health equipment. The study was carried out in the region of Butantã (SP), with a population of 428,217 inhabitants and sought to analyze the actions and flows related to the rehabilitation of health equipment through discussion wheels with professionals of six Primary Health Care and Ambulatory Care, and three interviews with users. 57 professionals from different categories participated in the discussion, who elaborated flowcharts that later were superimposed on those that represent the users' trajectories. In addition, the analysis of the flow of referrals of rehabilitation demands from Primary Health Care to Specialized Care in the period from 2012 to 2016 was carried out. The reports have given rise to reflections on collective approaches as a care tool in rehabilitation; the role and resolve of Specialized Care for long-term care and less common complaints; the magnified look of professionals; access to care actions, in view of the large displacements and waiting time for inclusion; informal networks as facilitators of access to technological resources; and the articulation difficulties of Rehabilitation Network. The average age of users waiting in the list during the period from 2012 to 2016 was 47.1 years $(S D=22.5)$ and the median age was 51 years (minimum age $=0$ years, maximum age $=102$ years). Were analyzed 44,022 referrals and the highest demands for referrals for the specialties were orthopedics (37.92\%), physiotherapy (21.47\%), pneumology (13\%), neurology $(9.22 \%)$, 
psychiatry $(5.79 \%)$ and acupuncture $(3.58 \%)$. The facilitation of access to rehabilitation actions and activities, as well as the articulation of the rehabilitation network and the recognition of their flows, can potentiate the rehabilitation process by increasing the resolving of care.

Descriptors: rehabilitation; delivery of health care; health services accessibility; health services needs and demand; primary health care; ambulatory care. 


\section{APRESENTAÇÃO}

Durante a graduação em Fisioterapia se fez muito presente a discussão da minha atuação como profissional de reabilitação nos contextos ambulatoriais e hospitalares, embora já se conhecesse a inserção de fisioterapeutas em outros cenários. A aproximação com o campo da Saúde Coletiva e Atenção Primária à Saúde (APS) se deu a partir de iniciativas pessoais através de atividades de extensão nas quais se debatiam os efeitos da organização do Sistema Único de Saúde (SUS), em caráter regional, no cuidado aos indivíduos de forma ampliada. Após um período de imersão na Estratégia de Saúde da Família (ESF), já formada, direcionei minha especialização para a temática das Redes de Atenção à Saúde (RAS) atuando na articulação dos equipamentos de saúde do município de Santos - SP. O aprofundamento no estudo do papel de cada um dos componentes das RAS e da atuação do fisioterapeuta e da equipe multiprofissional nos mesmos possibilitou expandir meus conhecimentos e instigar novas estratégias de cuidado, reelaborando minha identidade profissional. Como requisito para a conclusão da pós-graduação, analisei dois modelos tecnoassistencias da APS sob a perspectiva dos profissionais de saúde.

Posteriormente, como fisioterapeuta, pesquisadora e preceptora de graduação em APS pude vivenciar mais de perto a rede de atenção à reabilitação da região do Butantã (São Paulo, SP), atuando com os profissionais de saúde e compartilhando das potencialidades e barreiras do cotidiano da assistência e da coordenação do cuidado a saúde da população de referência.

Este trabalho surgiu a partir da observação das demandas dos gestores e profissionais da rede de reabilitação da região do Butantã, principalmente atuantes em equipamentos de atenção primária à saúde e especializada. Em fóruns de discussão organizados pela Supervisão Técnica de Saúde do Butantã (STS), foram discutidas temáticas relacionadas a oferta de serviços, capacitação profissional e fluxos de encaminhamento de pacientes na região e para outros equipamentos de referência do município de São Paulo. Estes fóruns mensais que aconteceram até meados de 2017 constituíam-se em espaços de troca de 
experiências na gestão do cuidado e da clínica nos serviços da região que, embora próximos, apresentavam organizações, recursos humanos, ofertas de atividades, território, perfil populacional e vivências diversas.

A população residente na região do Butantã (São Paulo - SP) é marcada pela estreita convivência com o campus da Universidade de São Paulo, em exercício desde 1968 (SÃO PAULO, 2017) e pela articulação das iniciativas de assistência, ensino e pesquisa com os órgãos municipais e estaduais. No que tange a área da saúde, a região conta com a assistência do Hospital Universitário, inaugurado em 1981 (SÃO PAULO, 2018a) e entre os anos de 2009 a 2016 contou com o Projeto Região Oeste mediante o contrato da Fundação Faculdade de Medicina com a Prefeitura do Município de São Paulo para a gestão dos equipamentos de Atenção Primária à Saúde (APS) da região (SÃO PAULO, 2018b). Diante da perspectiva de término do contrato e mudança na gestão da maioria dos equipamentos de atenção primária à saúde, realizou-se o esforço de registrar as ações e atividades de cuidado em saúde desenvolvidas a fim documentá-las e buscar a continuidade das mesmas. Durante o período de atividade do fórum, foram realizados registros acerca das ofertas de ações e atividades dos equipamentos de saúde, dos critérios e fluxos de encaminhamento para tais e dos protocolos de indicação, solicitação e dispensação de órteses, próteses e meios auxiliares de locomoção.

Tal estudo foi motivado pela expectativa de vislumbrar as diferentes formas de organização interna dos equipamentos de saúde da região do Butantã, como modo de responder às demandas e necessidades da população em relação à reabilitação e promover o cuidado longitudinal e integral às pessoas e nos diferentes pontos da rede de atenção. Pensou-se ainda na contribuição aos gestores, profissionais e indivíduos desta região, a medida em que seriam reconhecidas as estratégias de gestão do cuidado e da clínica que tem como base características específicas para sua construção, sob as quais interferem os aspectos objetivos e subjetivos das relações interpessoais e dispositivos organizacionais adotados. 


\section{INTRODUÇÃO}

A Organização das Nações Unidas (2006) entende por reabilitação o processo que visa ao alcance e manutenção da funcionalidade de pessoas com deficiências, sob o ponto de vista físico, sensorial, intelectual, psíquico e/ou social. Através dele acredita-se que os sujeitos poderão modificar suas realidades, adquirindo autonomia e independência.

O termo pode ser definido também como um conjunto de ações voltadas ao aumento das habilidades dos usuários com diminuição dos danos, de suas incapacidades e deficiências; incluindo as pessoas com doenças crônicas e doenças degenerativas (Faro, 2004; Lussi, 2006). A incapacidade é definida como: "um termo que inclui deficiências, limitação da atividade ou restrição na participação" pela Classificação Internacional de Funcionalidade, Incapacidade e Saúde (CIF). Ambos conceituam a reabilitação como um processo de amplas dimensões e caráter contínuo, que inclui o contexto social e ambiental dos usuários.

No Brasil, as primeiras instituições criadas para atender as necessidades e demandas de saúde das pessoas com deficiência e incapacidades surgiram em na década de 40 , por iniciativa da sociedade civil, atribuindo às instituições filantrópicas e de caridade a responsabilidade pela assistência em serviços que eram voltados estritamente para crianças e pessoas com deficiência mental. Durante décadas os esforços dos órgãos públicos em organizar serviços de reabilitação eram insuficientes e ainda na década de 1960 as poucas iniciativas existentes eram organizadas na atenção hospitalar. Com a criação do Sistema Único de Saúde (SUS) em 1988 os programas de reabilitação passaram a ser geridos por órgãos federais, centralizando assim as ações e as disponibilizando na rede pública de saúde. Manteve-se assim as iniciativas filantrópicas inicialmente organizadas, que por vezes estabeleceram contratos para oferecer atendimento à rede pública (Ribeiro, 2010). Os serviços de reabilitação estavam alocados em centros especializados, responsáveis por procedimentos de média e alta densidade tecnológica com baixa cobertura e resolubilidade. Estes equipamentos 
estão localizados em regiões urbanas economicamente favorecidas que não inclui uma parcela significativa da população nacional (Mitre, 2013).

Com a proposta de organização do SUS a partir de Redes de Atenção à Saúde (RAS) e a formação de organizações poliárquicas de equipamentos de saúde que atuem de forma cooperativa e interdependente, objetivou-se oferecer acompanhamento longitudinal coordenado pela Atenção Primária à Saúde (APS) a estes usuários e promover uma atenção à saúde baseada nas condições de saúde da população (Mendes, 2010).

As RAS devem ser organizadas a partir da necessidade e demandas de saúde da população. No Brasil, dentre as consideradas prioritárias ("Cegonha" que tem um recorte de atenção à gestante e de atenção à criança até 24 meses, "Atenção às Urgências e Emergências", "Atenção Psicossocial", "Atenção às Doenças e Condições Crônicas", "Cuidado à Pessoa com Deficiência"), a de atenção às doenças e condições crônicas e de cuidado à pessoas com deficiência são as que mais se aproximam dos arranjos organizativos de ações de reabilitação (Brasil, 2012a; Brasil, 2012b; Brasil, 2013).

Com base na Política Nacional de Saúde da Pessoa com Deficiência (Brasil, 2010b) que propõe a integralidade do cuidado e a construção de redes de atenção articuladas, regionalizadas e intersetoriais, ampliou-se a discussão sobre a práxis da reabilitação nos equipamentos de saúde, educação e assistência social. Visando à garantia de direitos e ao cuidado à saúde das pessoas com deficiência, foram propostas estratégias para o acolhimento dos usuários e suas famílias, para o delineamento de um plano terapêutico comum aos profissionais e para o compartilhamento e discussão do próprio fazer das equipes de profissionais (Mitre, 2013).

Os desafios encontrados para a integração das RAS demandam uma análise voltada para três níveis: o macropolítico - no qual são tomadas decisões relacionadas ao direito à saúde, acesso, cobertura, financiamento e macrorregulação -; o intermediário - em que estão um conjunto de atividades de suporte necessários para o desenvolvimento das práticas de saúde -; e o 
micropolítico, que diz respeito à interação entre os profissionais e usuários (Conill, 2007).

Do ponto de vista macropolítico, as RAS são constituídas por três elementos: a população, a estrutura operacional e o modelo de atenção à saúde. O conhecimento acerca da população e do território para o qual uma RAS se organiza contribui para a elaboração de um planejamento que considere as necessidades de saúde e os riscos sócio ambientais específicos, sob os quais possam se desenvolver ações. A estrutura operacional das RAS é constituída pelos diferentes pontos de atenção à saúde e pelos sistemas de integração de apoio, logísticos e de governança (Brasil, 2010a; Mendes, 2010).

Esta abordagem requer que os equipamentos de saúde se organizem de modo a expandir as possibilidades de cuidado para além dos serviços especializados, como historicamente foi estabelecido, e para tanto o cuidado dos usuários deve se fazer presente nos diferentes equipamentos de saúde e níveis de atenção, bem como fora deles: nos territórios nos quais as pessoas vivem (Faro, 2004; OMS, 2004). A proposta de uma configuração em Rede descentraliza o cuidado, corresponsabilizando todos os serviços que a compõe: Atenção Básica, Atenção Especializada e Atenção Hospitalar e de Urgência e Emergência. Para isto devem ser definidas as ações ofertadas por cada nível de atenção para que estes se articulem estabelecendo processos e fluxos de cuidado implicados com a realidade social e o meio em que os usuários vivem (Campos, 2015). Faz-se necessária uma reflexão acerca do papel que os trabalhadores exercem no territórios e no equipamentos em que atuam, considerando que as percepções destes atores são influenciadas pelas concepções prévias que têm em relação a estes lugares (Merhy, 2014). Entender estas percepções em cada ponto da rede de cuidados e das relações estabelecidas com os demais equipamentos e com os usuários é criar significado para que este encontro potencialize a integralidade. Os arranjos organizativos de ações e atividades nos equipamentos de saúde devem compor uma sequência, interna e externa, de etapas que traçam fluxos de utilização dos serviços. Estes são determinados pela necessidade de saúde, pelos 
usuários, pelos prestadores de serviços, pela organização e pela política (ROESE, 2008).

Para os usuários dos sistemas de saúde, os fluxos são correspondentes à procura por uma ação terapêutica ou o caminho percorrido pela busca de atendimentos resolutivos. Porém, a utilização dos serviços é equivalente a todos os contatos diretos ou indiretos e deve considerar o comportamento individual dos usuários e seus modos de enfrentar as dificuldades do dia-a-dia, e a relação entre os usuários e os profissionais que o conduzem no sistema de saúde (Roese, 2008).

Para Merhy (2014), as Redes Vivas correspondem aos aspectos micropolíticos das Redes analógicas - manejáveis do ponto de vista racional e com certa previsibilidade das formas de fazer. As Redes Vivas são dinâmicas e mutáveis de acordo com a singularidade das necessidades e demandas dos usuários. Entretanto existem inter-relações destas redes a medida em que uma rede analógica institucional será influenciada pelo caminho que os usuários fazem e pelas formas de se conectar com cada um dos pontos. A partir daí, torna-se possível o estabelecimento de redes que englobem o conjunto de estratégias e modos de viver dos usuários às quais se destinam e abarquem a subjetividade dos profissionais envolvidos, buscando firmar novas conexões que sejam significativas para o cuidado em saúde e para a própria vida dos envolvidos neste encontro.

Deste modo a dimensão micropolítica citada anteriormente assume um papel fundamental no delineamento das Redes de Cuidado em Saúde por se aproximar do real e demonstrar as potencialidades da constituição de redes permeadas pelos aspectos singulares, territoriais e intersetoriais. Ademais, atribui ao usuário o protagonismo na constituição de suas próprias redes que vão além dos planos terapêuticos e dos espaços formalmente estabelecidos para seu cuidado (Merhy, 2014).

É fundamental compreender os aspectos macropolíticos e micropolíticos das Redes, bem como os percursos históricos e as transformações que contribuíram para a constituição das diferentes formas de organização dos sistemas de 
saúde. E ainda, refletir sobre a indissociabilidade entre as práticas clínicas e a gestão do ponto de vista micropolítico e macropolítico, com base nos atores que realizam a gestão em seus diversos níveis dentro e fora dos equipamentos de saúde é indispensável (Mendes, 2010; Merhy, 2014).

Nesse contexto, entende-se a gestão do cuidado em saúde como a disponibilização das ações e atividades de cuidado em saúde de acordo com as necessidades singulares dos usuários, com o objetivo de promover, manter ou recuperar a saúde nos diferentes momentos de vida. Esta gestão, pensando-se em saúde, possui diversos componentes individual, familiar, profissional, organizacional, sistêmica e societários (Cecilio, 2011). Já as necessidades de saúde consistem nas ações fundamentais para se ter saúde, com base na concepção dos usuários, e nos serviços de saúde considerados essenciais para oferecer o cuidado em saúde, do ponto de vista dos profissionais. Assim, dependem da disponibilidade de serviços e agilidade na oferta do cuidado, e também das características particulares dos sujeitos a quem as ações se destinam. Relacionam-se também às vulnerabilidades apresentadas pelas populações, indo além das doenças, sofrimentos e riscos (Herr, 2014; Hino, 2009).

No que se refere às Redes de Atenção prioritárias, com objetivo de atender as "necessidades de enfrentamentos de vulnerabilidades, agravos ou doenças que acometem as pessoas ou as populações", observa-se uma insuficiente articulação entre os equipamentos de saúde que se dá, majoritariamente, por meio de documentos institucionais esvaziados de significados para os profissionais de saúde. Nota-se ainda que tal iniciativa não contempla, e dificilmente o faria, outras necessidades de saúde, tais como a reabilitação em sua concepção ampliada (Faro, 2004; OMS, 2004). O desafio posto é de como integrar as tecnologias relacionais à macrogestão a fim de não perder de vista as necessidades dos usuários, disponibilizando meios para o seu cuidado.

$\mathrm{O}$ acesso aos equipamentos de saúde, entendido como a facilidade de se obter cuidados em saúde ou o alinhamento entre a busca e o ingresso nos equipamentos de saúde (Almeida, 2017; Travassos, 2004), está intimamente ligado à relação entre os usuários e os equipamentos e à oferta de ações e 
atividades (Travassos, 2006). É importante diferenciar o acesso e o uso de serviços dos equipamentos de saúde, sendo o uso dado a partir da combinação entre a necessidade, a percepção, as características sociodemográficos e os valores do indivíduo; a organização e a forma de financiamento do sistema de saúde (Travassos, 2004). Ainda, a regulação dos sistemas de saúde são dispositivos de controle do acesso aos equipamentos de saúde e formas de regulamentar e elaborar regras de uso dos serviços neles contidos, tornando-se uma das organizadoras dos fluxos estabelecidos entre os equipamentos de saúde (Oliveira, Elias, 2012).

A utilização dos serviços formalizando o acesso a cada encontro do usuário com os profissionais de saúde (Almeida, 2017), atribui aos usuários parte do protagonismo no contato inicial com os equipamentos de saúde em busca de cuidados. A outra parte se dá aos profissionais pela condução dos usuários dentro do sistema de saúde, a determinação do tipo e da intensidade e recursos necessários para responder às demandas apresentadas. Os determinantes do uso dos serviços estão relacionados à necessidade de saúde; às características demográficas, geográficas, socioeconômicas, culturais e psíquicas dos usuários; aos profissionais de saúde; ao tipo e organização dos equipamentos de saúde; e à política do sistema de saúde (Travassos, 2004).

Há de se considerar também que a disponibilidade de oferta pode induzir o uso de serviços não relacionados às necessidades de saúde dos usuários, muito embora mais comumente a rede de atenção à saúde disponibilize ações insuficientes ou fragmentadas para o cuidado (Travassos, 2000). Atualmente, o acesso à reabilitação nos equipamentos de saúde é limitado, sendo quase inexistente na rede assistencial os profissionais que contribuem no processo de reabilitação das pessoas com incapacidades e deficiências (Hajjioui, 2015). Dessa forma, uma das tarefas mais urgentes é a expansão e adequação da oferta das ações e serviços de reabilitação, com consolidação da rede de atenção à saúde, visando ampliar o acesso, a efetividade e a eficiência.

Diante do contexto, faz-se necessário, portanto, compreender a gestão do cuidado de reabilitação, as demandas atendidas e reprimidas e as ofertas de 
serviços para ampliar o acesso e a integralidade do cuidado para as pessoas com incapacidades e deficiências. 


\section{OBJETIVOS}

\subsection{Geral}

Compreender a gestão do cuidado da Rede de Atenção à Reabilitação de uma região de São Paulo.

\subsection{Específicos}

- Identificar e analisar os fluxos internos relacionados à reabilitação nos equipamentos de saúde;

- Identificar e analisar os fluxos relacionados à reabilitação entre os equipamentos que constituem a rede;

- Descrever e analisar as demandas atendidas e reprimidas em relação às ações e atividades desenvolvidas na atenção especializada de reabilitação. 


\section{MÉTODOS}

\subsection{Desenho do Estudo}

O estudo apresenta duas partes. O trabalho qualitativo buscou conhecer e descrever as ações, atividades e fluxos relacionados à reabilitação presentes nos equipamentos de saúde da região estudada. O trabalho quantitativo, transversal, analisou as características dos estabelecimentos de saúde, dos recursos humanos e de solicitações de serviços de atenção especializada para as demandas de reabilitação.

\subsection{Local e População de estudo e Amostra}

O estudo foi desenvolvido na região sob responsabilidade da Supervisão Técnica de Saúde do Butantã que pertence à Coordenadoria Regional de Saúde Oeste do município de São Paulo. De acordo com o Instituto Brasileiro de Geografia e Estatística (Brasil, 2016), a população estimada do Estado de São Paulo para 2015 é de 44.396.484 habitantes. A cidade de São Paulo possui 11.581.798 habitantes (São Paulo, 2016a), sendo 428.217 habitantes na região analisada (São Paulo, 2016b). Para tanto, participaram deste estudo: i. os profissionais dos equipamentos de saúde localizados na área de abrangência da Supervisão Técnica de Saúde Butantã que compõem a Rede de atenção à reabilitação, englobando equipamentos da Atenção Primária à Saúde e Atenção Especializada; ii. os usuários indicados pelos profissionais dos equipamentos de saúde estudados; iii. os encaminhamentos da atenção primária à saúde para a atenção especializada de reabilitação.

Segundo dados da Secretaria Municipal de Saúde (São Paulo, 2015b), a Supervisão Técnica de Saúde Butantã é responsável por 29 equipamentos de saúde: 15 equipamentos de Atenção Primária à Saúde (APS): UBS Butantã com 1 Equipe Multidisciplinar de Atenção Domiciliar - EMAD Butantã, UBS Caxingui Nanci Abranches, UBS Jardim Boa Vista, UBS Jardim D'Abril com 1 equipe do 
Núcleo Ampliado de Apoio à Saúde da Família e Atenção Básica - NASF-AB, UBS Jardim Jaqueline, UBS Jardim São Jorge com 1 equipe NASF-AB, UBS Dr. José Marcílio Malta Cardoso UBS Paulo VI com 1 equipe NASF-AB, UBS Real Parque "Dr.Paulo Mangabeira Albernaz Filho", UBS Rio Pequeno "Dr.Paulo de Barros França, UBS São Remo, UBS Vila Borges, UBS Vila Dalva "Eng. Guilherme Henrique Pinto Coelho", UBS Vila Sônia e o Centro de Saúde Escola Samuel Banrsley Pessoa; sete equipamentos de Atenção Especializada ( $A E)$ : Centro de Atenção Psicossocial - (CAPS) Adulto Butantã, CAPS Infanto-Juvenil Butantã, Centro Especializado em Odontologia Butantã, Centro Especializado em Reabilitação (CER) Butantã, Centro de Convivência e Cooperativa (CECCO) Parque Previdência, Hospital Dia da Rede Hora Certa Butantã - AE PERI PERI, Serviço de Atenção Especializada DST/AIDS - Butantã; 2 equipamentos de Atenção Hospitalar (AH): Hospital Municipal e Maternidade Prof. Mário Degni (Hospital Sarah), Hospital Universitário da Faculdade de Medicina da Universidade de São Paulo (HU); 5 equipamentos de Urgência e Emergência: AMA Jardim PeriPeri, AMA Jardim São Jorge, AMA Paulo VI, AMA Vila Sonia e o Pronto-Socorro Municipal Dr. Caetano Vírgilio Neto (PMS Butantã). Além disso, atua no território a Supervisão de Vigilância em Saúde do Butantã (SUVIS Butantã).

As aprovações dos Comitês de Ética da Faculdade de Medicina da Universidade de São Paulo (protocolo 1.754.917) e da Secretaria Municipal de Saúde de São Paulo (protocolo 1.808.137) encontra-se em anexo (Apêndice 1).

Participaram do estudo três equipamentos de saúde de APS e três equipamentos da $A E$ que aceitaram participar da pesquisa após esclarecimento presencial dos pesquisadores. Os equipamentos de APS apresentavam diferentes modelos tecnoassistenciais, um com cobertura de ESF na totalidade de seu território e os outros dois em um modelo misto de UBS tradicional com uma porção do território coberta pela ESF. Destes últimos, um apresentava a atuação de uma equipe do NASF-AB e o outro uma equipe multiprofissional associada ao equipamento. Os equipamentos de $A E$ apresentavam diferentes conformações organizacionais, sendo referência para a região do Butantã, com territórios adscritos diversos. Buscou-se analisar também a influência do modelo 
tecnoassistencial na participação na rede de reabilitação.

Nos equipamentos de saúde participantes do estudo, realizou-se o convite aos profissionais durante reunião pré-agendada, após consentimento do gestor local. Os pesquisadores procuraram enfatizar a importância da participação do maior número de categorias profissionais que estejam envolvidos no processo de cuidado de reabilitação, buscando ampliar a compreensão das atividades/ações desenvolvidas e incrementar a elaboração compartilhada do material. Tal relevância se deve à contribuição singular de cada um dos profissionais envolvidos no processo de acolhimento, encaminhamento interno e externo dos usuários com necessidades voltadas à reabilitação. Os profissionais foram convidados a colaborar com a pesquisa mediante o esclarecimento prévio, manifestação de concordância e assinatura do Termo de Consentimento Livre e Esclarecido - TCLE (Apêndice 2).

$O$ roteiro de perguntas disparadoras para a facilitação dos grupos de discussão encontra-se em anexo (Apêndice 3). O produto desses grupos possibilitou identificar a viabilidade para construir a descrição das ações e serviços de reabilitação e os fluxos de referência e contrarreferência e analisá-los.

Durante a realização de reuniões de esclarecimento sobre o estudo e convite dos profissionais e a realização dos grupos, os pesquisadores fizeram o registro de suas percepções, a fim de colaborar com informações para a análise dos dados. Os pesquisadores também participaram dos espaços já estabelecidos para discussão do planejamento e prática na rede de atenção à reabilitação da região e realizaram registros para o estudo.

Foram explicados os objetivos da pesquisa e pactuados dias e horários para a coleta dos dados, com base na demonstração de interesse em participar. Em cada um dos locais são seguidos os procedimentos abaixo:

I. Encontro com o responsável pelo equipamento (gestor local) para apresentar os objetivos da pesquisa;

II. Realização de reunião para convidar os profissionais e pactuar data e horário para a coleta;

III. Realização do grupo de discussão para coleta de dados. O tempo médio 
para cada coleta em cada equipamento foi de 90 minutos e 10 profissionais;

IV. Realização de novo grupo de discussão para devolutiva, ajustes e validação das ações, atividades e fluxos referentes ao cuidado de reabilitação.

Foram realizadas entrevistas com usuários indicados pelos grupos de profissionais de saúde dos equipamentos estudados. Os grupos de profissionais identificaram usuários cujo cuidado em reabilitação envolveu diversos equipamentos da rede e que foram considerados marcantes para os mesmos, justificando os motivos das indicações. A partir das indicações, os usuários e familiares foram convidados a participar do estudo mediante o esclarecimento prévio, manifestação de concordância e assinatura do TCLE em anexo (Apêndice 4). Foram realizadas entrevistas nas quais foram narradas as experiências vivenciadas por estes usuários no seu próprio cuidado ou de seu familiar.

Os dados referentes às solicitações de serviços de atenção especializada foram obtidos por meio dos profissionais da Supervisão Técnica de Saúde que, após consentimento prévio para a realização da coleta, disponibilizaram dados do Sistema E-SUS (E-SUS), ao qual possuem acesso direto. Foram importados dados em intervalos compatíveis com a capacidade de transferência dos arquivos do sistema e posteriormente unificados para análise no período de janeiro de 2012 a novembro de 2016.

\subsection{Critério de Inclusão}

Profissionais envolvidos no processo de reabilitação dos equipamentos de saúde da Supervisão Técnica de Saúde do Butantã da Coordenadoria Regional de Saúde Oeste do município de São Paulo (SP), que atuam no acolhimento, encaminhamento interno e externo dos usuários, na articulação da rede e na gestão em reabilitação.

Participaram do estudo profissionais de três equipamentos de saúde da APS, identificados com os nomes fictícios Batel, Paideia e Ubirajara e com diferentes modelos tecnoassistenciais. $E$ também três equipamentos da $A E$, sendo um em reabilitação, um em saúde mental e um centro de convivência e cooperativa, 
respectivamente identificados por Inhotim, Plantarum e Oitis.

Os usuários e familiares identificados pelos profissionais dos equipamentos de saúde como importantes para o relato de suas experiências na rede de reabilitação da Supervisão Técnica de Saúde do Butantã da Coordenadoria Regional de Saúde Oeste do município de São Paulo (SP) foram entrevistados e seus prontuários foram analisados.

Foram coletados os encaminhamentos realizados da atenção primária à saúde para a atenção especializada incluídos na lista de espera de janeiro de 2012 a novembro de 2016 para as seguintes especialidades: Acupuntura; Avaliador de Órteses; Próteses e Meios auxiliares de locomoção - Ortopédica; Especialista em Reabilitação Física; Fisiatria; Fisioterapia; Fonoaudiologia; Fonoaudiologia - Audiologia; Genética Clínica; Geriatria; Hansenologia; Neurocirurgia; Neurologia; Odontologia - Atendimento a pacientes com necessidades especiais; Ortopedia; Pneumologia; Psicologia; Psiquiatria; Reumatologia; Serviço Social; Técnico de Órtese e Prótese; Terapia Ocupacional.

\subsection{Critério de Exclusão}

Serão excluídos profissionais e usuários que a qualquer momento retirem o seu consentimento em participar do estudo; dados e documentos ilegíveis, rasurados ou inexistentes. Para os encaminhamentos, foram excluídos os que não corresponderam, conforme a CID - 10, ao Capítulo VII - Doenças do olho e anexos (H00-H59); Capítulo XI - Doenças do aparelho digestivo (K00-K93); Capítulo XVIII - Sintomas, sinais e achados anormais de exames clínicos e de laboratório, não classificados em outra parte (R00-R99); e Capítulo XXII - Códigos para propósitos especiais (U00-U99).

\subsection{Variáveis estudadas}

Os fluxos internos e entre os equipamentos relacionados à reabilitação são constituídos pela sequência de acessos e utilização dos ações e atividades. São 
coletados a partir de: i. documentos norteadores produzidos pelos profissionais e gestores existentes nos equipamentos; ii. materiais produzidos em grupos de discussões com os profissionais e gestores envolvidos no processo de reabilitação dos equipamentos de saúde, atuantes no acolhimento, encaminhamento interno e externo dos usuários; iii. prontuários e relatos da vivência dos usuários na rede de reabilitação da região.

A caracterização dos encaminhamentos para a atenção especializada foi feita a partir de dados coletados no sistema E-SUS: equipamento de saúde, idade do usuário em anos (a partir da data de nascimento), especialidade de encaminhamento, subespecialidade de encaminhamento, procedimento solicitado, tipo de atendimento, prioridade, data de inclusão na fila de espera, data de saída da fila de espera, capítulo da Classificação Estatística Internacional de Doenças e Problemas Relacionados com a Saúde - décima edição (CID-10) e status na fila de espera (Apêndice 5).

\subsection{Análise de Dados}

Os materiais elaborados nas rodas de conversa foram transferidos para arquivos digitais do programa draw.io Diagrams ${ }^{\circledR}$ no formato de fluxogramas, visando a facilitar a análise e exposição dos achados. Posteriormente, foi ressaltado nos fluxogramas as ações e atividades pelos quais os usuários participaram ou foram encaminhados, em fluxogramas representativos das trajetórias de cuidado.

Adotou-se como referência o fluxograma descritor (Merhy, Franco, 1997; Merhy, Franco, 2003) para representar os processos de trabalho e detectar as dificuldades e facilidades dos mesmos. A partir da construção coletiva foi proposta a reflexão acerca das ações de saúde realizadas pelos profissionais dos equipamentos de saúde de modo a repensar as ofertas e organização destas. Nos fluxogramas apresentados, as figuras geométricas representam, respectivamente: Círculo ou elipse - entrada ou saída do processo de produção de ações e atividades; Losango - momentos em que deve haver uma decisão para a 
continuidade do trabalho; Retângulo - o momento de intervenção, ação sobre o processo.

Os usuários indicados pelos profissionais dos equipamentos de saúde configuraram casos traçadores que constituem em uma estratégia de investigação utilizada em diferentes áreas de conhecimento (Feuerwerker, 2016). Os casos foram desenhados prospectivamente e suas análises possibilitaram compreender de forma longitudinal o processo de cuidado adotado pelos usuários e seus familiares, direcionados por eles e pelos profissionais de diferentes equipamentos de saúde.

Os caminhos delineados pelos usuários na procura pelo cuidado em saúde foram analisados quanto a articulação dos equipamentos de saúde e entre eles, conforme dados obtidos nas rodas de conversa e nas entrevistas realizadas com os usuários. Foram identificados nos fluxogramas as potencialidades e barreiras encontradas para o desencadeamento do cuidado aos usuários, tanto pelos profissionais dos equipamentos de saúde (graficamente representado pelas cores verde - potencialidades e vermelha - barreiras), quanto pelos pesquisadores (graficamente representado pelas setas em negrito - potencialidades e tracejadas - barreiras). Foram identificados nas entrevistas as dificuldades e facilidades encontradas pelos usuários durante o processo de cuidado em saúde.

Nos prontuários dos usuários participantes foram coletados dados cronológicos de ações e atividades de cuidado que os mesmos foram orientados a participar e equipamentos da rede para os quais os usuários foram encaminhados.

Os dados numéricos foram armazenados em banco no Programa Microsoft Excel. Como recurso estatístico, foi utilizado o programa Stata, versão 14,0 para realizar a análise descritiva das solicitações de serviços de atenção especializada e da caracterização dos estabelecimentos de saúde. 


\section{RESULTADOS}

\subsection{Equipamentos da Rede de Atenção à Reabilitação}

Abaixo estão expostos os fluxos da rede de atenção à reabilitação dos seis equipamentos de saúde da região do Butantã, São Paulo - SP, sendo três equipamentos da APS e três da AE. Foram utilizadas siglas e abreviaturas que constam nas listas inicialmente apresentadas para descrever as ações, acometimentos de saúde, atividades e identificar as categorias dos profissionais atuantes nos equipamentos. $O$ quadro 1 as retoma:

Quadro 1: Apresentação das siglas e abreviaturas utilizadas nos fluxogramas para indicar ações, acometimentos de saúde, atividades e categorias profissionais.

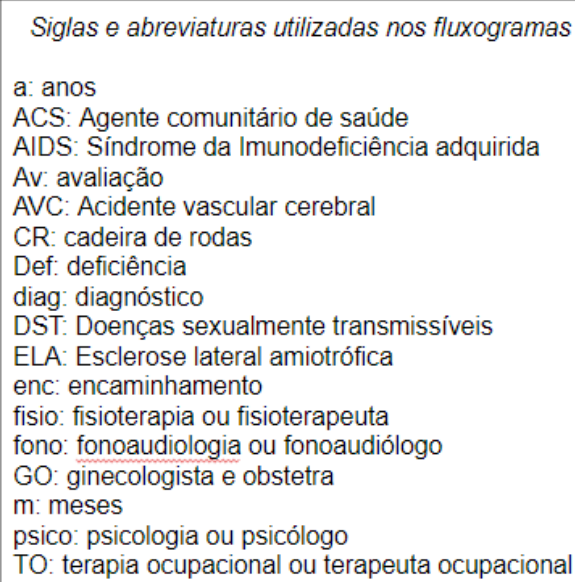

\subsubsection{Equipamento Batel}

$\mathrm{Na}$ figura 1 observamos o equipamento Batel. Participaram da roda de conversa 8 profissionais, entre eles ACS, fisioterapeutas, enfermeiros, psicólogos e técnicos de enfermagem.

O equipamento de APS Batel se organiza através do modelo 
tecnoassistencial de APS tradicional associada a Estratégia Saúde da Família (ESF). Possui trê equipes de Saúde da Família, que contam com médico, enfermeiro, técnicos de enfermagem e ACS. Conta ainda com equipe de Saúde Bucal, equipe administrativa, assistente social, psiquiatra, psicólogo e fisioterapeuta que atendem as demandas de toda a população. No momento aguarda o início do trabalho de uma equipe NASF-AB composta por fisioterapeuta, fonoaudiólogo, nutricionista e psicólogo e profissional de educação física, que atenderá a população coberta pelas equipes de ESF.

No fluxograma observa-se que o acesso às ações e atividades de reabilitação se dá através de sete inserções, sendo dois de profissionais internos ao serviço - levantamento de demandas e necessidades por busca ativa dos ACS ou em reunião de equipe da ESF -, um de equipamentos de Urgência e Emergência, um de equipamentos da $A H$, dois de equipamentos da $A E$, sendo um geral e um em saúde mental e um a partir da busca espontânea da população, o qual apresenta demanda crescente devido ao fechamento de equipamentos de saúde da região e dificuldade de acesso aos outros equipamentos disponíveis. $O$ acesso às ações e atividades de reabilitação é direcionado através da recepção, que classifica as demandas e necessidades em três categorias: pessoas com questões crônicas relacionadas à reabilitação, pessoas com questões agudas relacionadas à reabilitação sem encaminhamento e pessoas com questões agudas relacionadas à reabilitação com encaminhamento.

As pessoas com questões crônicas relacionadas à reabilitação são orientadas a agendar consulta com clínico, pediatra ou equipe de ESF para, após $o$ atendimento, realizarem o agendamento da primeira consulta com fisioterapeuta na regulação do equipamento de saúde. As pessoas com questões agudas relacionadas à reabilitação sem encaminhamento são direcionadas ao acolhimento no mesmo período, atendidas pelos médicos, enfermeiros ou assistentes sociais e orientadas a agendar consulta com clínico, pediatra ou equipe de ESF. Após a consulta agendada, são encaminhadas à regulação para realizar o agendamento da primeira consulta com fisioterapeuta. Pessoas com questões agudas relacionadas à reabilitação que possuem encaminhamento são 
direcionadas pela recepção à regulação para agendamento da primeira consulta com fisioterapeuta de Batel. Todas os usuários que vão à regulação com encaminhamentos internos ou externos a Batel são colocadas em fila de espera para a primeira consulta com fisioterapeuta conforme ordem de prioridade.

$\mathrm{Na}$ primeira consulta com fisioterapeuta podem ser realizadas orientações, inserções para atendimento individual de fisioterapia e inserções para cuidados coletivos (seis temáticas de grupos conforme condições de saúde). Pacientes que possuam critérios de encaminhamento para a $A E$ são direcionados após a primeira consulta com fisioterapeuta para equipamentos de $A E$ municipal e estadual, universidades e, informalmente, para atendimento domiciliar (municipal) ou para hospital terciário da região que dispõe de reabilitação para crianças e adolescentes.

A inserção para cuidados coletivos de Batel foi apontada como uma potencialidade, dada a diversidade de oferta de abordagens e maior disponibilidade de vagas para a população. Os encaminhamentos externos para serviços de reabilitação foram considerados barreiras para o cuidado pelos profissionais de Batel e pelos pesquisadores, devido ao acesso restrito por critérios de inclusão e pela disponibilidade de cerca de duas vagas por mês para encaminhamento. As OPM apresentaram via única de encaminhamento, sendo ele externo para o equipamento de $\mathrm{AE}$ em reabilitação municipal, também considerado uma barreira para profissionais e pesquisadores.

Os profissionais referem ainda demandas não absorvidas pelo cuidado interno ao equipamento de APS e que também não se incluem nos critérios para equipamentos de $\mathrm{AE}$ em reabilitação, referindo não haver fluxos e possibilidades de encaminhamento nestes casos. 


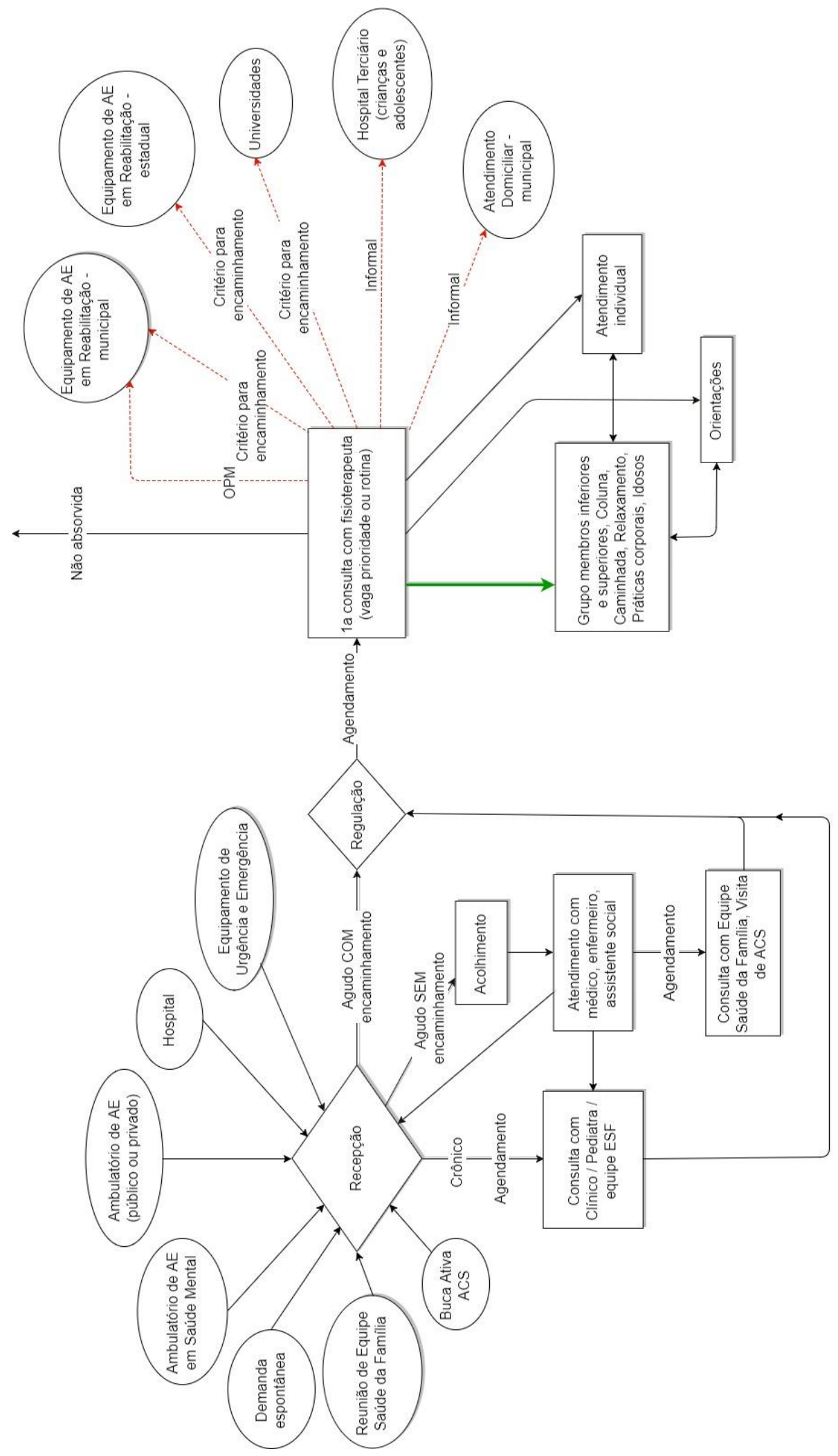

Figura 1: Fluxograma das ações e atividades de reabilitação do equipamento Batel, 2017. 


\subsubsection{Equipamento Paideia}

A figura 2 representa o equipamento Paideia, no qual 21 profissionais de diferentes categorias participaram da roda de conversa. Foram elas: agentes comunitários de saúde (ACS), auxiliar administrativo, auxiliar de enfermagem, assistente social, enfermeiro, fisioterapeuta, médico, odontólogo e profissional de educação física.

O equipamento de APS Paideia se organiza através do modelo tecnoassistencial da Estratégia Saúde da Família (ESF), com cobertura total do território adscrito. Possui quatro equipes de Saúde da Família, uma equipe de Saúde Bucal e uma equipe do Núcleo Ampliado de Saúde da Família e Atenção Básica (NASF-AB) compartilhada com outro equipamento de saúde. Há ainda profissionais da equipe administrativa e assistentes sociais que atualmente estão sendo incorporados ao NASF-AB.

No fluxograma observa-se que 0 acesso às ações e atividades de reabilitação se dá através de sete inserções, sendo três de profissionais internos ao serviço (odontólogo para casos de gestantes, crianças maiores de 36 meses e casos de fonoaudiologia; assistente social para as demandas identificadas na figura; e equipe de Saúde da Família), um de equipamentos de Urgência e Emergência, que apresenta demandas de atendimento e de órteses, próteses e meios auxiliares de locomoção (OPM), e três de equipamentos intersetoriais com demandas de OPM. $O$ acesso às ações e atividades de reabilitação se dá exclusivamente através da deliberação em reunião das equipes da ESF que direcionam, conforme as demandas e necessidades de cuidado, a abordagem inicial de profissionais médicos ou enfermeiros da própria equipe e posteriormente aos profissionais do NASF-AB para atendimentos ou questões relacionadas a OPM, que serão direcionadas a dois equipamentos da rede através de três vias.

Observa-se a oferta de ações de cuidados individuais no equipamento e em domicílio (visita domiciliar) com os profissionais do NASF-AB (fisioterapeuta, nutricionista, psicólogo, profissional de educação física e terapeuta ocupacional) para os quais os participantes relatam a dificuldade de acesso dada inexistência 
de profissionais de todas as categorias e alta necessidade da população por avaliação e atendimento. Quanto a oferta de cuidados coletivos, os profissionais das equipes ESF têm acesso direto a cinco abordagens grupais a partir dos critérios de inclusão, fato que os pesquisadores consideraram como potencialidade, dada a diversidade de temáticas e à articulação interna para inclusão através de critérios formais.

Há o encaminhamento de usuários a quinze diferentes equipamentos da $\mathrm{AE}$ sendo três por vias informais, entre elas uma exclusiva para o acesso a cuidados de fonoaudiologia da região. Tais vias foram consideradas barreiras pelos pesquisadores, devido a indisponibilidade de tais articulações na rede de reabilitação e a inconstância na possibilidade de encaminhamento relatada pelos profissionais durante a roda de conversa. Os pesquisadores consideraram ainda os fluxos de identificação de demandas com compartilhamento na reunião da equipe como uma potencialidade, denotando a importância destes atores no reconhecimento das demandas e necessidades dos usuários do território adscrito e na coordenação do cuidado dos mesmos, atribuições essenciais da APS.

Nota-se ainda a inexistência de fluxos de encaminhamento estabelecidos para demandas relacionadas às disfunções mandibulares, para as quais anteriormente era feita uma articulação informal com uma instituição de ensino que deixou de ofertar tais cuidados.

$O$ encaminhamento para $O$ ambulatório de $A E$ para três especialidades médicas (ortopedia, reumatologia e vascular), bem como o ambulatório de psicologia conveniado, foram identificados como barreiras para os profissionais e o último para os pesquisadores, dada a baixa oferta de vagas e dificuldade de agendamento para atendimentos. Todo o fluxo de encaminhamento relacionado a demandas de OPM foram considerados barreiras pelos profissionais devido a baixa disponibilidade de acesso, reorganização do fluxo municipal para solicitação, prescrição e dispensação dos materiais, exceto para as solicitações de calçados, para as quais foi aberta licitação pública e contratada empresa privada no período imediatamente anterior a pesquisa.

Vale citar que os profissionais participantes não identificaram potencialidades 
nos fluxos estabelecidos dentro e entre os equipamentos, atribuindo a isto o momento de realocação de profissionais e equipes no território do Butantã, acarretando imprevisibilidade na organização interna do equipamento e da manutenção das ações e atividades, e também incerteza da configuração organizacional da rede de reabilitação da região. 


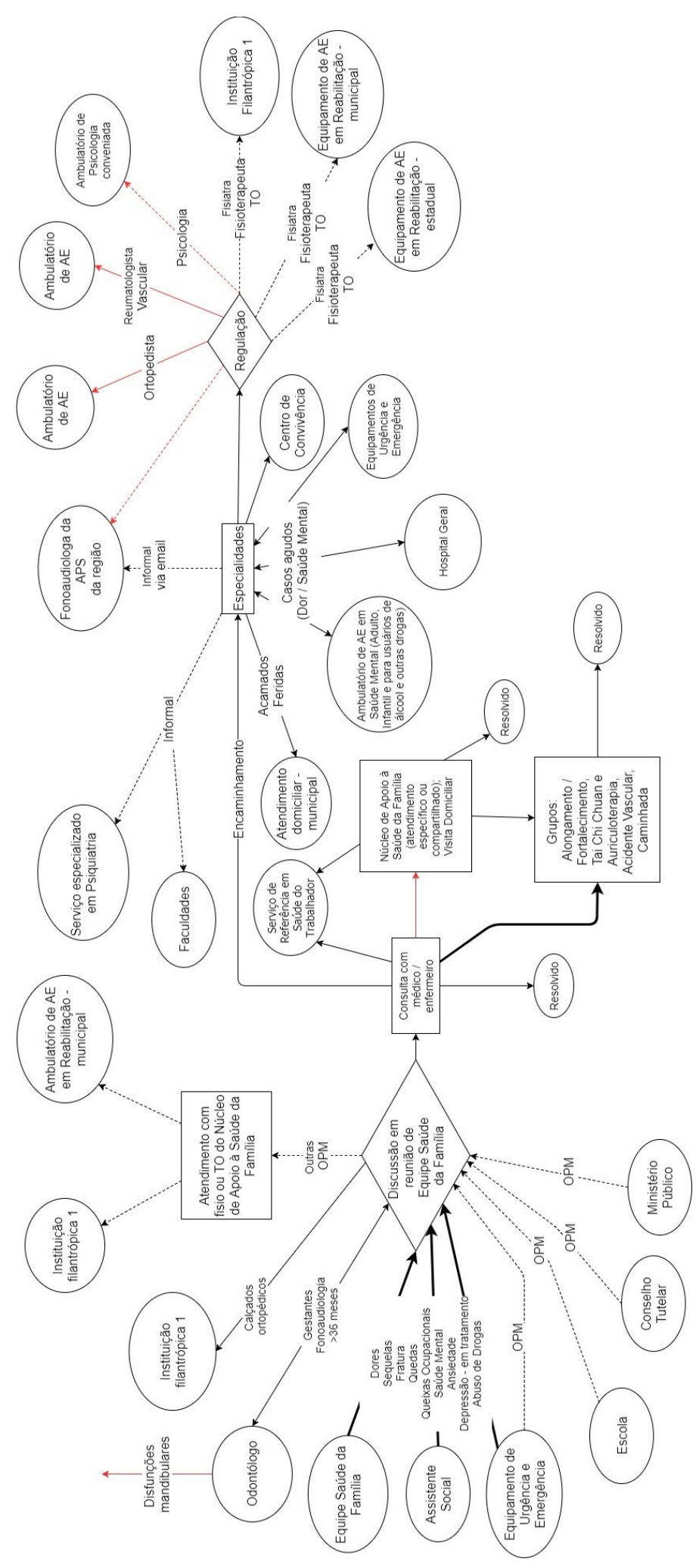

Figura 2: Fluxograma das ações e atividades de reabilitação do equipamento Paideia, 2017. 


\subsubsection{Equipamento Ubirajara}

A Figura 3 representa o equipamento Ubirajara, no qual cinco profissionais de três categorias participaram da roda de conversa: ACS, auxiliar administrativo e auxiliar de saúde bucal. O equipamento de APS Ubirajara se organiza através do modelo tecnoassistencial de APS tradicional associada a Estratégia Saúde da Família (ESF). Possui duas equipes de Saúde da Família, sendo uma equipe de ESF e uma equipe de Saúde Indígena que contam com médico, enfermeiro, técnicos de enfermagem e ACS. Conta ainda com equipe de Saúde Bucal, equipe administrativa, assistente social, psiquiatra, psicólogo e terapeuta ocupacional que atendem a população adscrita de todo o território do equipamento. E conta também com clínico, enfermeiro, ginecologista, pediatra e técnicos de enfermagem que atendem a população da região que não é coberta pela ESF.

No fluxograma observa-se que o acesso às ações e atividades de reabilitação se dá através de treze vias. Destas, onze são de equipamentos externos: seis de equipamentos de $\mathrm{AH}$, três de Urgência e Emergência, um de serviços particulares ou convênios e um de escolas e creches. Profissionais internos ao serviço representam mais uma via de inserção e a demanda espontânea dos usuários também uma. Os profissionais justificam a multiplicidade de oferta de equipamentos de $\mathrm{AH}$ e Urgência e Emergência na região devido ao fato de que Ubirajara se localiza na divisa da região Oeste com a região Sul do município e seus equipamentos de $\mathrm{AE}, \mathrm{AH}$ e Urgência e Emergência de referência são distantes, além da pouca oferta de transporte público para acesso. Sendo assim, a população utiliza equipamentos que não seriam referência direta a ela, mas que ofertam a assistência necessária, principalmente no que tange a abordagens pontuais.

O acesso às ações e atividades de reabilitação em todas estas vias se dá através da recepção diretamente, ou após abordagem inicial na farmácia para usuários que procuram dispensação de medicamentos. Atividades coletivas de cuidado apresentam acesso direto através da procura espontânea do usuário ou do encaminhamento dos profissionais de todas as categorias do equipamento, 
conforme critérios de inclusão (presença de nove temáticas distintas). Tais atividades foram consideradas pelos profissionais e pesquisadores como potentes para o cuidado da população, por terem fácil acesso e disponibilidade contínua de vagas, exceto o grupo de Tabagismo, que pode apresentar lista de espera devido a quantidade de insumos necessários.

A partir da recepção do equipamento os usuários podem ser agendados para atendimento com médico ou enfermeiro das equipes de ESF e indígena, ou com profissionais que atendem o restante do território. Caso os usuários já possuam encaminhamentos para $\mathrm{AE}$ ou $\mathrm{AH}$, estes são direcionados à regulação para agendamento ou aguardo em lista de espera. Em casos de queixas urgentes, os usuários aguardam para o acolhimento com enfermeiro ou consulta médica, podendo ter suas necessidades e demandas de saúde sanadas, serem orientados a agendar retorno com profissionais do equipamento ou ser encaminhados para equipamentos de Urgência e Emergência. A articulação para 0 atendimento no equipamento e para a articulação com a rede nestes casos foi considerada uma potencialidade pelos pesquisadores, tendo em vista a organização de vias distintas de acesso aos atendimentos pelos profissionais de enfermagem e médicos, com base em critérios de necessidade e gravidade do quadro.

Observa-se a oferta de ações de cuidado individual in loco e em domicílio (visita domiciliar) por todas as categorias profissionais e espaços de deliberação acerca do cuidado ofertado em reuniões das equipes de ESF e saúde indígena.

Ubirajara se articula com a rede de reabilitação através de 14 possibilidades de encaminhamento, sendo dez para a $\mathrm{AE}$ e quatro para a $\mathrm{AH}$. Os profissionais referem dificuldade de interlocução e encaminhamento para eles, devido a reduzida oferta de vagas e às distâncias entre os equipamentos de saúde, principalmente do equipamento de $\mathrm{AE}$ em reabilitação municipal de referência e a AE em DST e AIDS. Estes são considerados como barreiras na rede tanto pelos profissionais quanto pelos pesquisadores. $O$ equipamento de $A E$ em Saúde Mental é uma exceção, tendo em vista que o mesmo realiza o acolhimento do usuário sem necessidade de agendamento prévio e durante todo o seu horário de funcionamento, sendo considerado uma potencialidade no fluxo da rede. 
Em relação à saúde indígena, há ainda a priorização do encaminhamento para a $A E$ em Saúde Indígena, possibilitando um acesso mais rápido e articulado da equipe de saúde indígena para o cuidado de seus usuários. A equipe ainda tem a disposição um veículo para o transporte dos usuários com atendimento agendado, o que faz com que os profissionais e pesquisadores atribuam a este fluxo potência e maior resolutividade.

Durante a roda de conversa observou-se dificuldade no aprofundamento do fluxo de OPM, que foi delineado a partir da solicitação dos profissionais de serviço social e terapia ocupacional, em contato direto com a gestão de saúde pública regional. Tais informações contrariam os fluxos de indicação, prescrição e dispensação estabelecidos na região e descritos pelos demais equipamentos de saúde e usuários da rede de reabilitação e foram considerados barreiras para 0 acesso pelos pesquisadores. 


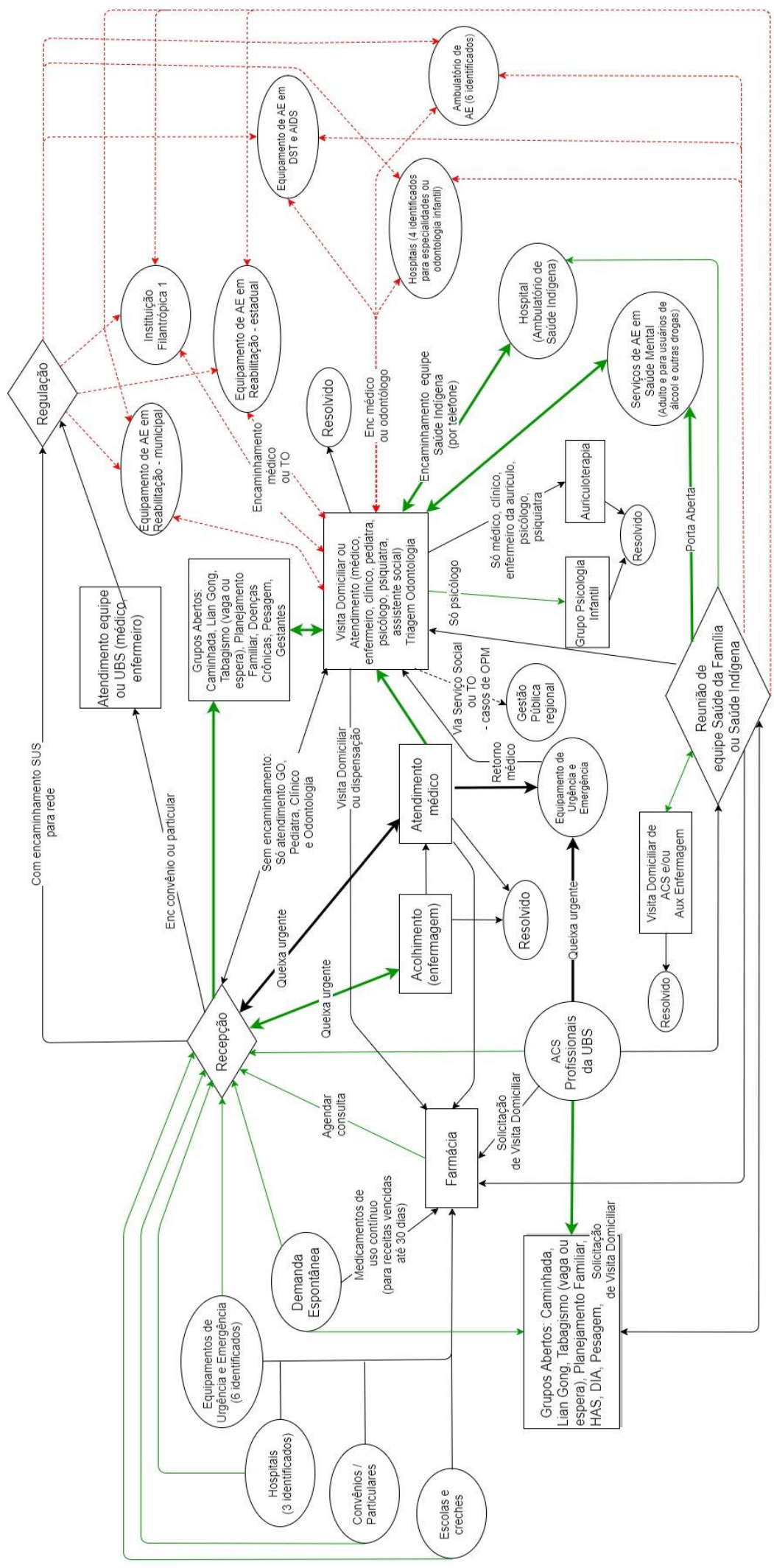

Figura 3: Fluxograma das ações e atividades de reabilitação do equipamento Ubirajara, 2017. 


\subsubsection{Equipamento Inhotim}

A figura 4 representa Inhotim, um equipamento de municipal de $A E$ em reabilitação, de referência para o território do Butantã. Participaram da roda de discussão dez profissionais de diferentes categorias, entre elas fisioterapeutas, fonoaudiólogos, gestor, psicólogos e terapeutas ocupacionais, contemplando cinco das seis categorias profissionais que nele atuam, com exceção dos auxiliares administrativos.

Foram identificadas seis vias de entrada para as ações e atividades oferecidas pelo por Inhotim. O serviço de atendimento domiciliar municipal encaminha os usuários com indicação de órteses de membros superiores (MMSS) ou OPM, sendo as órteses de MMSS prescritas, confeccionadas e acompanhadas por Inhotim e as demais OPM apresentarem diferentes fluxos: dispensação de meios auxiliares de locomoção e cadeiras de roda padrão por Inhotim; inserção na lista de espera para órteses pré-fabricadas, sapatos e coletes ortopédicos; encaminhamento para instituição filantrópica 1 via fisiatra para próteses de membros inferiores e encaminhamento para a regional do município para inclusão no mutirão de cadeiras de rodas adaptadas realizado a partir da determinação do ministério público.

$O$ equipamento de $A E$ realiza encaminhamento via ortopedista para 0 acolhimento multiprofissional de ortopedia (interno e externo) conforme critérios especificados e posteriormente os usuários são inseridos nos atendimentos individuais, cuidados em grupo, por vezes com necessidade de discussão prévia em reunião de equipe. $O$ equipamento de $A E$ encaminha via dermatologista para a avaliação simplificada para hanseníase para depois serem inseridos em atendimento com fisioterapeuta ou terapeuta ocupacional. Os usuários são encaminhados então para oftalmologista em ambulatório de $\mathrm{AE}$ e informalmente para a vigilância dermato-sanitária estadual para sapatos, cursos e benefícios da assistência social, através de e-mail. Já o equipamento de $A E$ em odontologia realiza encaminhamento à fonoaudiologia de Inhotim por via informal pacientes com perfil neurológico ou pessoas com deficiência. 
A gestão pública regional entra em contato telefônico ou por e-mail com a administração de Inhotim e solicita atendimento para pacientes com deficiência auditiva, disfagia, dificuldades de linguagem ou situações de urgência, que posteriormente serão direcionados para atendimento individual de fonoaudiologia ou acolhimento multiprofissional com posterior discussão em reunião de equipe, constituindo mais uma via informal de acesso.

A central telefônica municipal realiza agendamento de atendimento em Inhotim para crianças de até 12 meses de idade a partir de contato telefônico dos equipamentos de APS, maternidades ou dos próprios familiares, com vagas semanais reservadas na agenda de terapia ocupacional. Após acolhimento com fisioterapeuta e terapeuta ocupacional é realizada reunião da equipe de profissionais que atende especificamente estes bebês, que podem direcionados para atendimento individual (até 3 anos de idade) ou cuidado coletivo em grupo de bebês.

Os serviços de APS representam a sexta via de entrada para ações e atividades de Inhotim, sendo duas para demandas de prescrição de órteses de membros superiores e OPM, anteriormente descritas $e$ as demais para acompanhamento terapêutico. Os usuários são agendados via sistema municipal informatizado, conforme perfil de necessidades e demandas.

Usuários com deficiências ortopédicas, fraturas, que passaram por traumas, cirurgias ou imobilizações há até 6 meses (perfil ortopédico) são direcionados para o acolhimento multiprofissional de ortopedia para serviços externos com fisioterapeuta, psicólogo e terapeuta ocupacional. Após o acolhimento, os mesmos podem ser direcionados para atendimento individual com estas mesmas categorias profissionais, cuidado coletivo em grupos de cinco diferentes temáticas ou terem suas questões discutidas em reunião geral para posterior inserção nestas atividades.

Usuários com deficiências auditivas, acometimentos neurológicos agudos (há até 1 ano e 6 meses do evento) e doenças neurodegenerativas são atendidos em acolhimento multiprofissional de neurologia por fisioterapeuta, fonoaudiólogo, psicólogo e terapeuta ocupacional, divididos por idade (de 1 a 17 anos ou de 18 a 
120 anos). Após o acolhimento, os profissionais realizam discussão em equipe para definir o plano terapêutico dos usuários, que pode incluir cuidado individual ou em grupo e/ou encaminhamento para equipamentos externos, a depender das necessidades e demandas identificadas.

Em situações em que as necessidades e demandas dos usuários não são sanadas por Inhotim, são realizados encaminhamentos a outros equipamentos da região. O encaminhamento para neuropediatra se dá a partir de uma via informal por e-mails para agendamento no ambulatório de $\mathrm{AE}$, bem como para a instituição filantrópica 2, que realiza atendimento para diagnóstico de síndromes genética e cujo encaminhamento é feito por telefone.

O centro municipal de apoio à inclusão, pertencente a secretaria de educação, apresenta via de encaminhamento através de encontros periódicos para discussão de casos, bem como o centro de convivência Oitis e no ambulatório de $A E$ em saúde mental infanto-juvenil e adulto, os últimos apresentando também acolhimento à demanda espontânea sem necessidade de agendamento prévio.

Usuários que já realizam acompanhamento com ortopedista ou dermatologista do ambulatório de $\mathrm{AE}$ da região podem ser reencaminhados por Inhotim, sendo que os que ainda não estão em acompanhamento com estes profissionais devem ser encaminhados via equipamentos de APS. Já o ambulatório de AE para atendimento de idosos recebe encaminhamento de Inhotim para usuários com disfagia, sendo os demais também encaminhados via equipamentos de APS.

A instituição filantrópica 1 , anteriormente mencionada por ser a referência para usuários que necessitam de próteses de membros inferiores, também recebe encaminhamento de Inhotim para atendimentos e avaliações acerca da necessidade de cirurgias e para aplicação de toxina botulínica.

$O$ equipamento de $A E$ em reabilitação estadual e a instituição filantrópica 3 não apresentam vias de encaminhamento, tendo de ser procurados diretamente por pacientes ou familiares para verificar elegibilidade para reabilitação a partir de critérios internos específicos. Neles são oferecidos acompanhamento para 
usuários com amputações e oficinas, acompanhamento terapêutico e hidroterapia, respectivamente.

Os equipamentos de cultura e lazer da região apresentam a última possibilidade de encaminhamento relatada pelos profissionais, oferecendo atividades físicas, culturais e artísticas para a população.

Durante a realização do grupo de discussão de Inhotim, apenas uma via de encaminhamento externo foi identificada como barreira tanto pelos profissionais quanto pelos pesquisadores por não existir equipamentos de referência para acompanhamento de usuários com deficiência intelectual isolada ou associada a outras deficiências. 


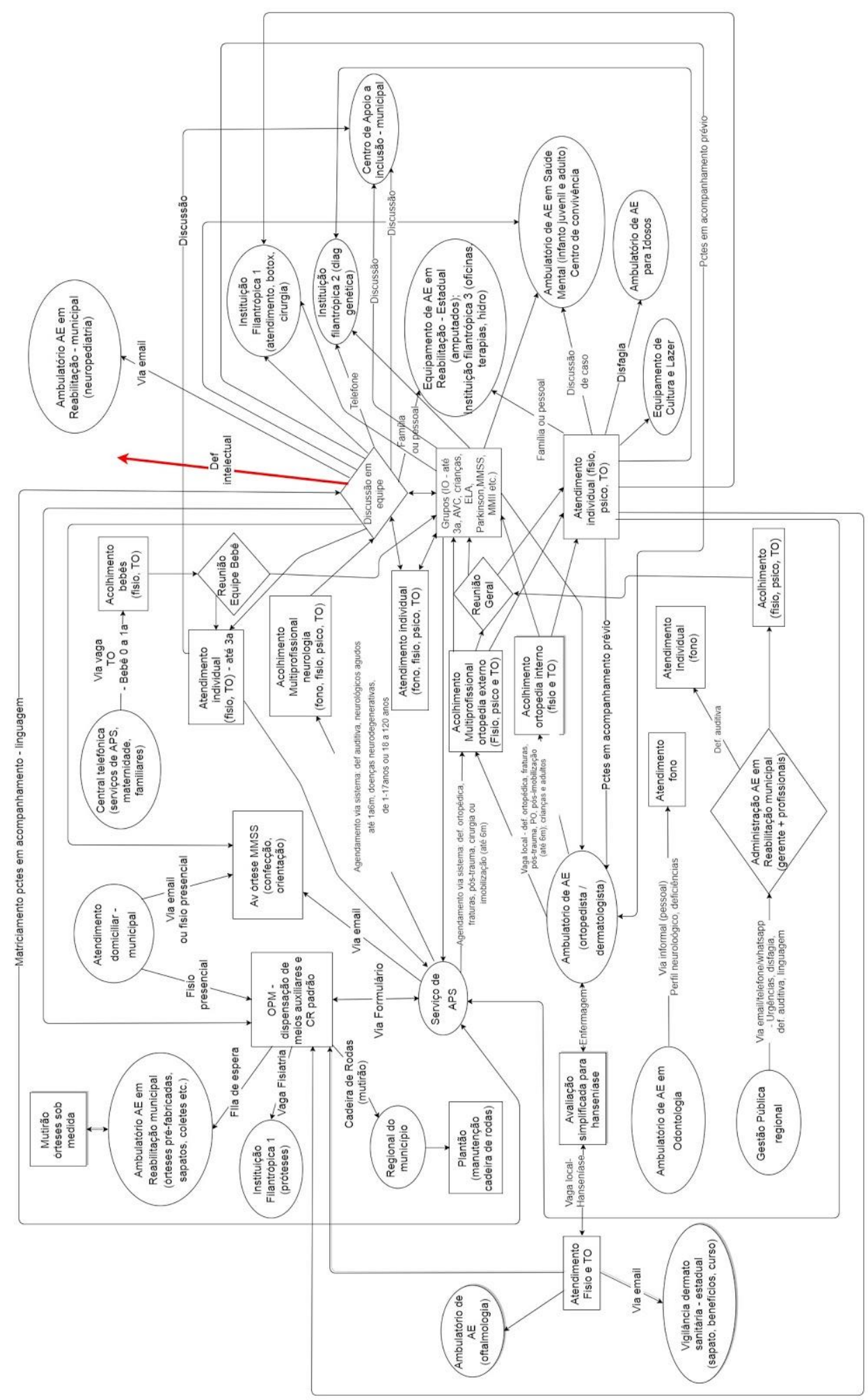

Figura 4: Fluxograma das ações e atividades de reabilitação do equipamento Inhotim, 2017. 


\subsubsection{Equipamento Oitis}

O Equipamento Oitis é um centro de convivência e cooperativa para usuários com questões de saúde mental e a população em geral, representado pela figura 5. Participaram da roda de discussão sete profissionais de duas categorias: psicólogos e terapeutas ocupacionais.

Observa-se que foram identificadas dez possibilidades de entrada para os usuários que utilizam o equipamento, entre equipamentos de saúde (dos três níveis de Atenção), educação, cultura, lazer, assistência social e organizações sociais. Relatou-se que quatro destas apresentam vias de mão dupla de encaminhamento e discussão de casos, sendo os equipamentos de APS com melhor articulação e facilidade de comunicação, identificado como uma potencialidade da rede.

O acesso a Oitis se dá sem necessidade de agendamento prévio, a partir do contato do usuário com profissionais de nível superior que realizam acolhimento e os orientam a se inserir nas atividades do equipamento. Os profissionais relatam a existência de quatro tipos de ações e atividades com frequências menores de realização de passeios, festas e eventos culturais, e frequência semanal de realização de oficinas com atividades artesanais, corporais, culturais e esportivas. 


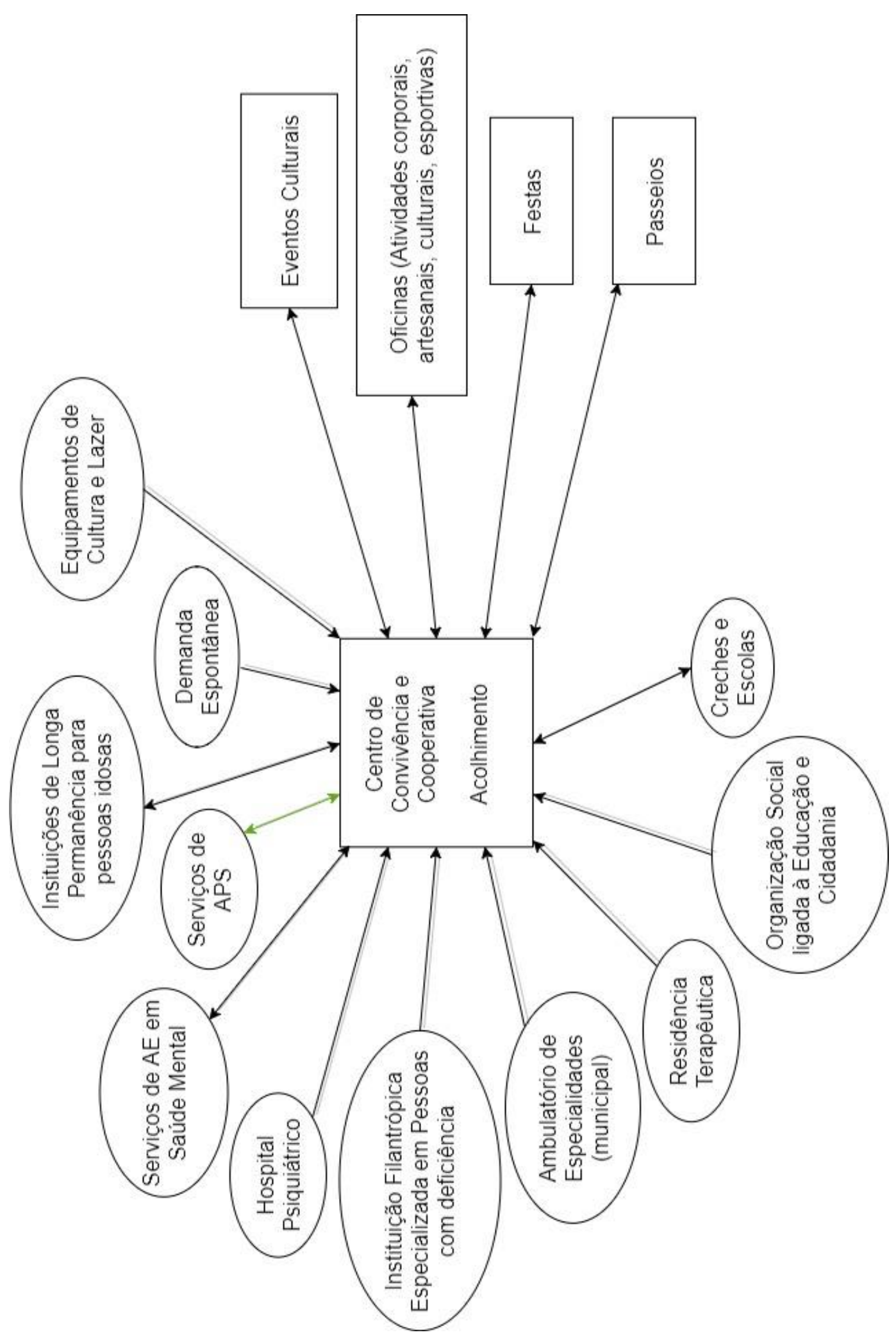

Figura 5: Fluxograma das ações e atividades de reabilitação do equipamento Oitis, 2017. 


\subsubsection{Equipamento Plantarum}

O equipamento Plantarum está representado pela figura 6. Trata-se de um serviço de $A E$ em Saúde Mental que atende adultos do território adscrito. Na roda de discussão participaram seis profissionais de diferentes categorias, entre elas: estagiário de psicologia, psicólogo e terapeuta ocupacional.

Foram identificadas onze vias de entrada para as ações e atividades do equipamento em questão, sendo sete provenientes de outros equipamentos de saúde, um de demanda espontânea dos usuários e três de órgãos intersetoriais como o ministério público, o conselho gestor da região e um equipamento da assistência social. Entre estes, os profissionais identificaram duas potenciais vias de entrada, provenientes do equipamento Oitis e de serviços de APS tais como Batel, Paideia e Ubirajara. Identificaram também como barreiras os encaminhamentos de usuários via ministério público e ambulatório de especialidades, dada a dificuldade de comunicação com profissionais destes serviços.

Ao acessarem o equipamento, os usuários são acolhidos por profissionais que rodiziam nesta função durante todo o horário de funcionamento do equipamento. $O$ acesso sem necessidade de agendamento é percebido pelos profissionais de Ubirajara como um fator potente para o funcionamento de Plantarum, entretanto tal atividade tem enfrentado dificuldades para ser mantida, dada a reduzida quantidade de profissionais atuantes em Plantarum. Em situações de evasão após o acolhimento inicial, é realizada a busca ativa através de visitas domiciliares aos usuários. Rotineiramente são realizadas reuniões de matriciamento com os serviços de APS e centro de referência especializado em assistência social de referência do território de referência, afim de alinhar as formas de encaminhamento a Plantarum e demandas e necessidades de saúde atendidas por este equipamento.

Após o acolhimento, é realizada reunião de equipe entre os profissionais de Plantarum para elaboração do Projeto terapêutico singular (PTS) do usuário, caso suas demandas e necessidades de saúde possam ser atendidas pelo 
equipamento. Pactuado o PTS com o usuário, este pode ser inserido nas atividades ofertadas por Plantarum, sendo elas uma de cuidado individual (atendimento individual com as especialidades ofertadas: enfermagem, psiquiatria, psicologia ou terapia ocupacional) e quatro de cuidados coletivos semanais (grupos de quatro temáticas e oficinas) ou eventuais (assembleias e festas). $O$ PTS é reavaliado periodicamente e discutido internamentos ao equipamento e com os demais equipamentos de referência para o usuário.

Plantarum estabelece articulações com equipamentos de cultura e lazer, saúde (serviços de APS; serviços de AE em Saúde Mental; centro de convivência e cooperativa - Oitis -; residências terapêuticas), educação (escolas e centros de integração e educação de jovens e adultos; universidades) e assistência social (centro de referência especializado em assistência social) para encaminhamentos e discussão acerca do cuidado dos usuários. Não foram identificadas potencialidades nos fluxos de encaminhamento para outros equipamentos e em nenhum deles sob o ponto de vista dos pesquisadores. 


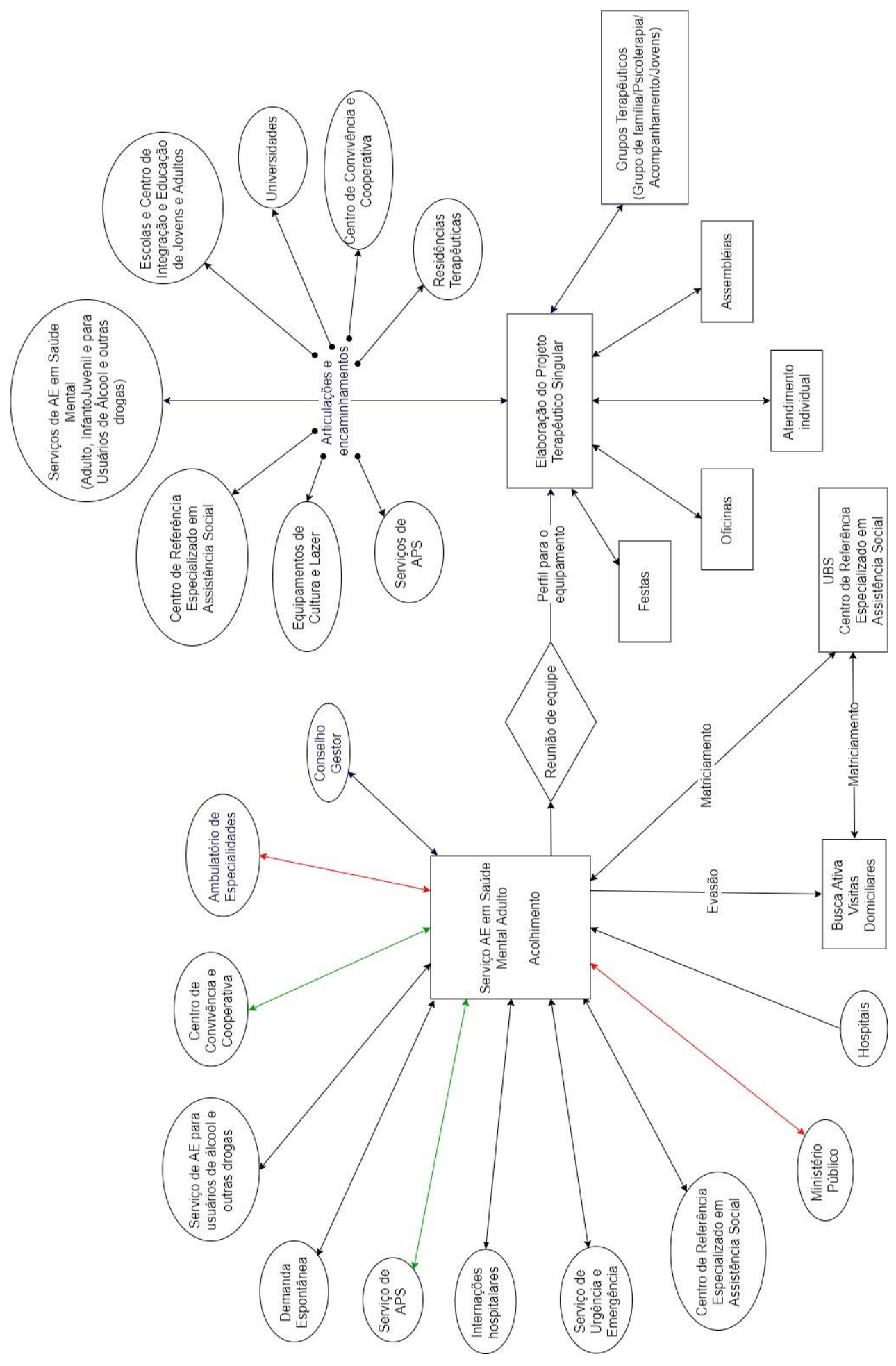

Figura 6: Fluxograma das ações e atividades de reabilitação do equipamento Plantarum, 2017. 


\subsection{A perspectiva dos usuários sobre o processo de cuidado}

A seguir serão apresentadas as vivências de três usuários e seus familiares pela rede de reabilitação da região estudada, compilados a partir das indicações dos profissionais de saúde de referência, registros em prontuário e dos próprios relatos dos usuários:

\subsubsection{Usuária Andorinha:}

- Indicação

Andorinha foi indicada pelos profissionais do equipamento Inhotim por estar na faixa etária de prioridade para atendimento, sendo o primeiro contato com a equipe de reabilitação no próprio equipamento e ter tido um acompanhamento longitudinal até então. O equipamento Inhotim foi novamente acessado quando esta deixou de realizar acompanhamento em outro serviço de reabilitação após encaminhamento de profissionais do Inhotim, demonstrando o papel de referência no cuidado da mesma.

Dentre os profissionais da atual equipe do equipamento Inhotim, permanece um que realizou o atendimento de Andorinha com 1 ano de idade. $O$ profissional relata a perceptível melhora do quadro motor de Andorinha, sinalizado pela maior autonomia e independência funcional. Acrescenta ainda o uso da cadeira de rodas como um facilitador para a melhora na funcionalidade, juntamente com a inserção escolar. Por fim, relata que a participação de Andorinha e sua mãe no atendimento em grupo ofertado por Inhotim se mostrou benéfico para o cuidado da usuária, tanto do ponto de vista da criação de uma rede de relações com profissionais e outros usuários do equipamento, quanto pela doação do meio auxiliar que ocorreu a partir da aproximação com a mãe de outra criança.

- Trajetória do cuidado 
Andorinha nasceu em seis de setembro de 2009, pré-termo (idade gestacional 36 semanas e 3 dias), em parto normal sem complicações e após alta hospitalar iniciou acompanhamento na UBS de referência. Aos 7 meses foi encaminhada pelo pediatra da UBS ao neurologista no equipamento de AE e para o equipamento Inhotim após consulta e relato da mãe de atraso no desenvolvimento neuropsicomotor (DNPM). Realizou seu primeiro atendimento em maio de 2010, no qual foi confirmado o atraso e agendada consulta com fonoaudióloga do equipamento Inhotim.

Após um período de faltas nos atendimentos, a mãe de Andorinha retomou os acompanhamentos e realizou exames para confirmação diagnóstica de má formação encefálica. Andorinha iniciou acompanhamento com fisioterapeuta e sua mãe com psicóloga devido a um quadro de depressão e foi realizada a primeira prescrição de cadeira de rodas. Em seguida Andorinha foi inserida na creche e observou-se significativa melhora no DNPM. Em 2012, a família começou a receber o auxílio da secretaria de assistência social.

Em 2013 Andorinha foi encaminhada para acompanhamento em uma instituição filantrópica de referência devido a saída dos fisioterapeutas no equipamento Inhotim por motivo de aposentadoria, transferência e readaptações ao posto de trabalho. Manteve-se o acompanhamento em ambos os serviços até a pactuação de acompanhamento periódico. Inhotim permaneceu cerca de dois anos sem fisioterapeutas e neste momento interrompeu-se o vínculo com Andorinha e sua mãe.

Em setembro de 2017 a UBS de referência realizou novo encaminhamento a Inhotim após solicitação da mãe de Andorinha, pois a família havia interrompido o acompanhamento terapêutico devido a distância, dificuldade de transporte e período de tempo despendido para comparecer aos atendimentos. Além disso, neste período Andorinha mantinha a frequência escolar em sala regular e sala de apoio e aguardava uma cadeira de rodas adaptada solicitada pela diretoria de ensino de referência já que, devido ao crescimento de Andorinha, a que utilizava não estava adequada.

$\mathrm{Na}$ avaliação inicial no equipamento Inhotim, foi pactuado retomar o 
acompanhamento individual com fisioterapeuta, para o qual Andorinha não compareceu durante um mês.

Em outubro de 2017 a mãe de Andorinha procurou novamente Inhotim e, após discussão de equipe, foi pactuado acompanhamento semanal em um grupo terapêutico com profissional de fisioterapia, psicologia e terapia ocupacional. Andorinha iniciou a participação em grupo e, a partir do contato com outras famílias com crianças com disfunções semelhantes, conseguiu uma doação de cadeira de rodas, a qual utilizou até a entrega da cadeira solicitada pela diretoria de ensino.

Relatou-se, neste momento, a evolução do quadro e o ganho de autonomia de Andorinha, que passou a conduzir sua cadeira de rodas e a realizar treino para andar com apoio em andador durante os atendimentos. Andorinha mantém acompanhamento trimestral com neurologista na $A E$ e com fonoaudiólogo, enfermeiro e médico na UBS de referência.

A figura 7, abaixo, sintetiza cronologicamente a trajetória do cuidado de Andorinha e sua passagem pelos equipamentos de saúde. 


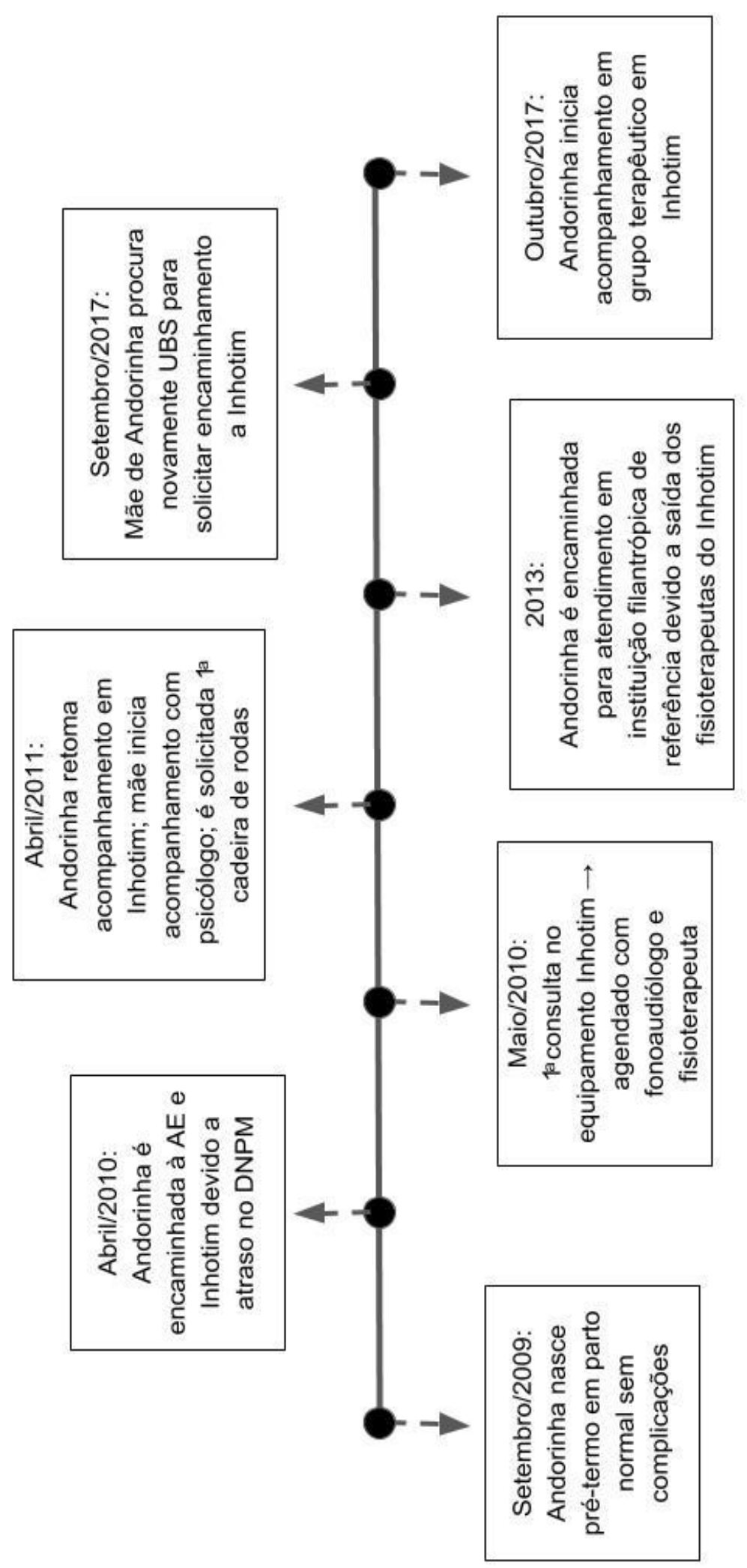

Figura 7: Linha do tempo da trajetória de cuidado da usuária Andorinha, 2018. 
O fluxograma a seguir ilustra a trajetória de cuidado de Andorinha pela Rede de reabilitação (em destaque). Em azul estão identificadas as entradas nos equipamentos de saúde estudados, em amarelo as ações e atividades que Andorinha realiza ou realizou durante seu cuidado e em vermelho aquelas que não foram realizadas ou para as quais Andorinha está aguardando. 


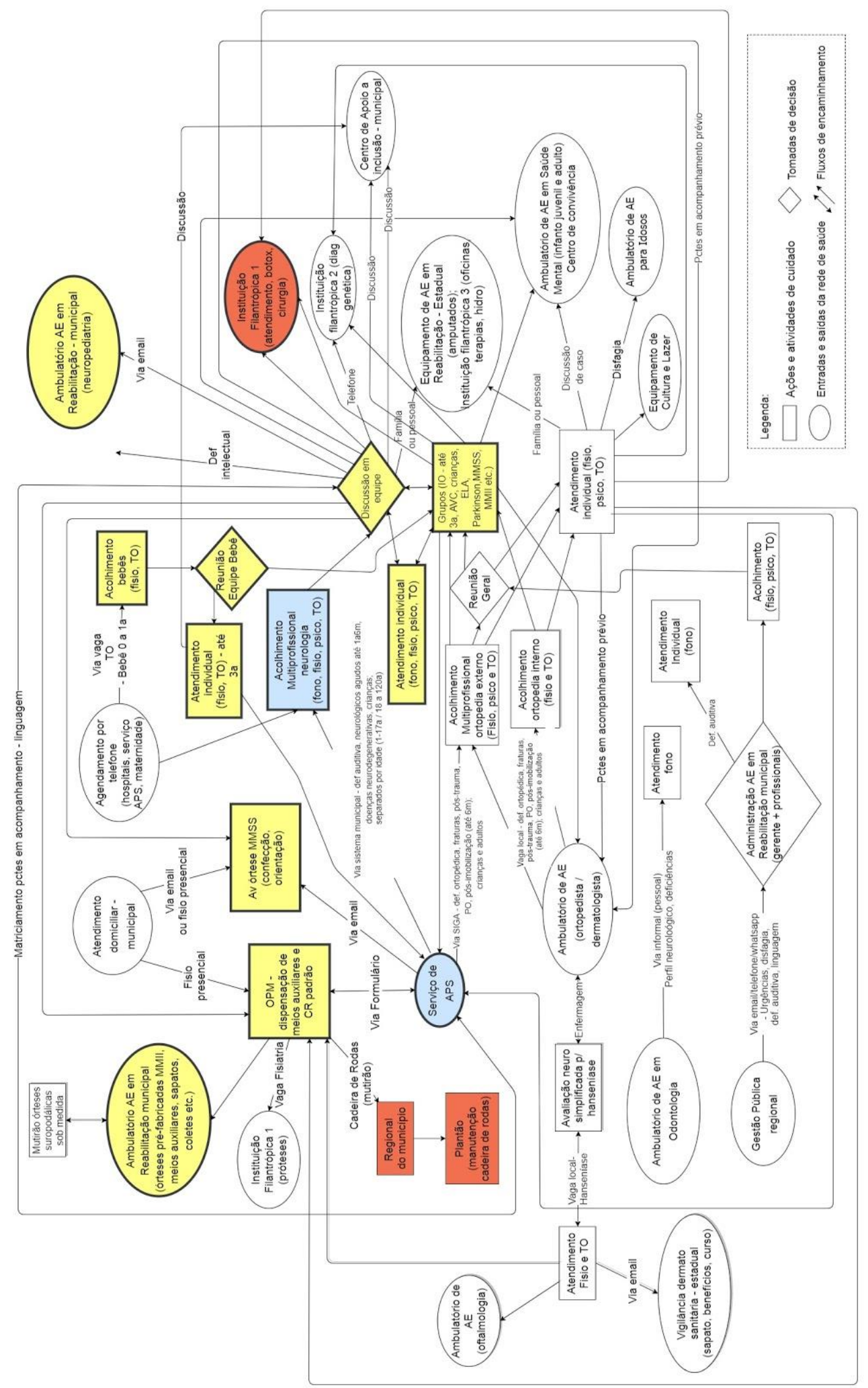

Figura 8: Fluxograma da trajetória de cuidado da usuária Andorinha, 2018. 
Durante a entrevista, a mãe de Andorinha relata a vivência de ambas pela rede de atenção à reabilitação, detalhando as potencialidades e barreiras encontradas e suas percepções acerca de alguns pontos centrais.

Em relação ao acesso aos equipamentos para os quais a filha foi encaminhada, refere a dificuldade de deslocamento e período de tempo despendido para o cuidado semanal na instituição filantrópica na qual a filha realizou atendimentos, em contraposição com o equipamento Inhotim:

"Seis e meia da manhã a perua (transporte municipal) me pegava e a consulta dela era onze horas. Eu ficava 40 minutos lá, então pra mim era cansativo e pra ela também... $E$ aí que foi em casa fono e TO da UBS, conversou conversou comigo e falou que ia encaminhar para cá." (Mãe de Andorinha)

"Eu venho de ônibus, às vezes quando meu genro tá de folga ele me traz, aí meu filho tá de folga e hoje ele me trouxe. Mas eu venho de ônibus porque pra mim aqui é perto, né..." (Mãe de Andorinha)

Problematiza ainda o processo para conseguir transporte municipal para levar Andorinha aos atendimentos agendados, motivo que também colaborou para a solicitação de novo encaminhamento aos profissionais da UBS. Faz contraponto aos trâmites para o transporte escolar municipal:

"Na instituição filantrópica de AE ela ia de perua. Depois de quatro anos eu consegui o transporte municipal..." (Mãe de Andorinha)

"(pra escola) ... é perto... mas mesmo assim eles me ligaram da escola e falou que mesmo morando perto ela tem direito 
ao transporte escolar, e foi aí que eu fiz o cadastro dela e ela vai começar a ir de perua a partir de semana que vem." (Mãe de Andorinha)

Sobre o acesso a órteses e meios auxiliares dos quais Andorinha necessitou em diferentes momentos de sua trajetória, são relatadas as diversas formas de indicação de prescrição que vivenciaram. Estabelece-se ainda um paralelo entre as solicitações dos equipamentos de saúde e educação:

"A primeira cadeira dela quem pediu, na época, foi a fisioterapeuta (de Inhotim) ... em três meses saiu a cadeira. Aí ficou pequena e nisso eu não sabia que tinha que pedir outra na instituição filantrópica de $A E$ assim que saísse, não pedi... Aí o coordenador da escola que pediu e com seis meses que saiu a outra cadeira.

Aí me deram uma de doação lá na instituição filantrópica de $A E$ que a dela quebrou, ela ficou usando depois quebrou também. Ela ficou um bom tempo sem ir pra escola por causa de cadeira.

Aí a escola que pediu outra que saiu também. Esta é a terceira cadeira dela." (Mãe de Andorinha)

"As órteses demorou pra sair. A primeira dela foi pedida pela instituição filantrópica de $A E$, demorou um ano e meio pra sair, a primeira goteira. E esta segunda que ela tá foi pela escola também, a escola que pediu e saiu rapidinho, mas já tá pequena também." (Mãe de Andorinha)

" A órtese que a TO do Inhotim está fazendo é para a mãozinha dela, que a dela tá meio pequena que foi feita na instituição filantrópica de $A E$, então tá bem pequena..." (Mãe 
de Andorinha)

Após a realização de um procedimento cirúrgico em membros inferiores, Andorinha realizou atendimentos individuais de fisioterapia na instituição filantrópica de referência em reabilitação conveniada ao SUS. A fala da mãe de Andorinha elucida o desconhecimento dos profissionais acerca do processo de solicitação de meios auxiliares de locomoção, muito embora o mesmo equipamento conveniado realizasse estes procedimentos anteriormente:

"Começou a fazer (fisioterapia). Ela fez um mês aí eu achava muito pouco e ela começou a fazer andador. Aí ela (fisioterapeuta da instituição filantrópica de $A E$ ) pediu pra mim: você tem condições de comprar?

Eu falei: eu não tenho, mas eu vou ver se eu consigo com a minha família juntar um dinheiro e comprar. Aí nisso a gente foi pesquisar na internet e saia muito caro o andador que ela pediu, e aqui ela conseguiu o andador. Já tá em casa o andador dela.... Ela treina aqui e treina em casa também." (Mãe de Andorinha)

É expressa ainda a percepção acerca do cuidado oferecido, sua resolutividade e adequação para as demandas e necessidades de saúde de Andorinha, sob o ponto de vista de sua mãe, que se mostra ativa na busca pelo cuidado e solicita novas possibilidades aos profissionais da UBS:

" Na instituição filantrópica de $A E$ faltou... Pegar no garfo, na colher, tudo ela pegou em casa..." (Mãe de Andorinha)

"A fono eu tava esperando há bastante tempo. O nome dela 
tava lá na instituição filantrópica de $A E$ na lista de encaixe $e$ não saiu. Às vezes em casa quem entende mais ela falar é eu. Eu e a outra irmã dela.... Não sei se é porque ela fala baixo, mas ela tem dificuldade na fala." (Mãe de Andorinha)

"Depois que eu pedi pra minha agente do posto de saúde...

Preciso falar com a doutora para ver se ela me encaminha para outros lugares, porque ela ficou na TO 8 meses e depois dispensou, a fisio aquática também ficou 6 meses e dispensou e depois ficou só na fisioterapia mesmo." (Mãe de Andorinha)

Por fim, a mãe de Andorinha expõe sua percepção sobre o cuidado em grupo no equipamento Inhotim, pontuando a melhora observada na funcionalidade da filha e o fato de se tratar de uma nova experiência, quando comparado ao primeiro contato com o equipamento.

"Eu gosto bastante, eles são bastante atenciosos, eu gostei. Porque eu tinha pedido pra encaminhar ela pra outro lugar e me mandaram pra cá... Agora que entrou o grupo, porque antigamente era separado..." (Mãe de Andorinha)

"Eu tô achando que tá ajudando bastante, porque a Andorinha tava muito parada, agora ela já se esforça. Ela mesma desce da cadeira sozinha, desce da cama sozinha, ela desce do sofá sozinha, ela mesmo senta. Mas dificuldade ela tem mesmo ao sentar...

\section{(...)}

Se deixar ela quer ficar só encostada... mas tá ajudando muito." (Mãe de Andorinha) 


\subsubsection{Usuária Macuco}

- Indicação

A usuária Macuco foi indicada pelos profissionais de sua equipe de ESF de referência do equipamento Paideia por ser acompanhada há cerca de 10 anos devido a uma condição social e de saúde complexa. Relatam que Macuco é uma usuária exigente, com boa adesão aos acompanhamentos, que apresenta queixa principal de dor em hemicorpo esquerdo após acidente vascular encefálico (AVE). Realiza acompanhamento em diferentes equipamentos da rede com pouca resolutividade para sua queixa principal.

Dentre os profissionais da atual equipe do equipamento Paideia, Macuco é acompanhada pela equipe de ESF, fisioterapeuta, profissional de educação física e psicólogo do NASF-AB, em atendimentos individuais e atividades coletivas de cuidado. Anteriormente foi acompanhada por terapeuta ocupacional, mas devido à demissão da mesma e redefinição dos profissionais que compõe a equipe NASF$A B, o$ acompanhamento foi interrompido.

- Trajetória do cuidado

A usuária Macuco tem 63 anos (nasceu em vinte e cinco de abril de 1955), é do sexo feminino e reside no território de referência do equipamento Paideia. Realiza acompanhamento no equipamento há mais de 10 anos para questões de saúde mental, com antecedentes pessoais de depressão, ideação suicida e alucinações auditivas.

Em março de 2009 teve o primeiro acidente vascular encefálico que se iniciou com sensação de "tontura" (sic) e dificuldade para se vestir. Foi levada ao equipamento de Urgência e Emergência da região e posteriormente transferida para a $\mathrm{AH}$. Após estabilização do quadro e realização de exames, a família foi informada acerca da gravidade do quadro e orientada a procurar uma instituição de longa permanência para internação. Recebeu alta hospitalar e foi encaminhada 
para acompanhamento no equipamento Paideia, no qual iniciou tratamento para hipertensão arterial sistêmica (HAS) e insuficiência cardíaca congestiva (ICC).

Apresentava incontinência, dificuldade auditiva, de fala e de mobilidade, permanecendo restrita ao leito e utilizando cadeira de rodas para locomoção. Em consulta em Paideia, foi encaminhada para a $A E$ de referência para a região, para avaliação e acompanhamento de neurologista e cardiologista, tendo as primeiras consultas em 2010. Foi agendado atendimento com fisioterapeuta de Paideia para tratamento da hemiparesia e deste para Inhotim após alguns atendimentos, no qual permaneceu por cinco a seis meses e para o qual tinha dificuldades financeiras para o deslocamento, contando com a ajuda de vizinhos para 0 custeio. Na mesma época teve auxílio de uma fisioterapeuta particular que cobrava um valor simbólico e a atendia em ambiente domiciliar. Durante este período percebeu melhora do controle fecal e miccional e na locomoção, conseguindo se deslocar em ambiente doméstico e evoluindo para deambulação com auxílio de bengala. Finalizou os acompanhamentos em Inhotim e com fisioterapeuta particular, mantendo o acompanhamento em Paideia.

Concomitante ao acometimento de saúde, relata conflitos familiares com o marido que iniciou uso abusivo de álcool e com o filho que iniciou uso de substâncias ilícitas e a ter alterações de comportamento.

No fim do mesmo ano, iniciou o acompanhamento com fisioterapeuta, profissional de educação física e terapeuta ocupacional da equipe NASF-AB de Paideia. Após avaliação, foi inserida em grupos de dor e artesanato, orientada a realizar hidroginástica em um serviço de cultura e lazer da região e recebeu uma visita domiciliar da fisioterapia e terapia ocupacional para adaptações que visassem facilitar a funcionalidade de Macuco no ambiente residencial. Foi orientada a participar das atividades do equipamento Oitis e da associação dos moradores do bairro.

Em outubro de 2011 apresentou novo episódio de AVE, com comprometimento motor em hemicorpo esquerdo e quadro de dor em membro superior esquerdo. Foi acompanhada em visita domiciliar por terapeuta ocupacional de Paideia, que sugeriu a retomada dos acompanhamentos em 
grupos (artesanato, caminhada, tai chi chuan, chi kung e dança circular), para os quais a usuária não compareceu. Ainda neste ano separou-se do marido, que apresentava problemas de saúde relacionados ao uso de álcool e recusa de cuidados familiares e profissionais, entretanto o conflito com ele não cessaram, o que acarretou consequências psicológicas negativas a Macuco, segundo ela mesma. Seu ex-marido viria a falecer em 2016, encerrando os conflitos familiares.

Evoluiu para quadro de dor em todo o hemicorpo esquerdo e em 2013 foi orientada a realizar acupuntura em um equipamento de $A E$ de referência municipal localizado na região central do município, conforme orientação da fisioterapeuta de Paideia. Não aderiu a orientação devido a distância, dificuldade financeira e de locomoção. Permaneceu em acompanhamento com fisioterapeuta de Paideia, participando do grupo da associação de moradores e de tai chi chuan. Em reavaliação com fisioterapeuta do NASF-AB, foi incluída no grupo de dor crônica de Paideia, mantendo também acompanhamento com terapeuta ocupacional.

Apresentou o terceiro episódio de AVE em fevereiro de 2014, o qual Macuco associa ao estresse vivenciado na relação com seus familiares. Manteve a queixa de dor em hemicorpo esquerdo e iniciou participação em grupo de Chi Kun, terapia comunitária integrativa, atividades no equipamento Oitis e acupuntura em um instituto privado de formação em medicina tradicional chinesa, recomendado pela fisioterapeuta de Paideia, que era mais próximo à residência de Macuco e para o qual a usuária desembolsava uma quantia financeira de custo.

Macuco refere grande aproximação com a ACS de referência e relata que sempre compartilhou com ela o desejo de conhecer e fazer atividades diferentes, de buscar "coisas" (sic) além das que existem no bairro em que vive e de conversar sobre o que acontece em outros lugares que ela considera menos violentos. Relata ter buscado atividades em diferentes serviços da rede de saúde e intersetoriais, além de atividades

Em setembro de 2014 apresentou o quarto episódio de AVE, com comprometimento motor em hemicorpo esquerdo e passou a ser atendida individualmente por fisioterapeuta e psicólogo em Paideia. Interrompeu a 
participação nos grupos de atividades físicas de Paideia, mantendo apenas o grupo de mulheres. Manteve acompanhamento com equipe de ESF, fisioterapeuta e psicólogo de Paideia, passando em atendimentos esporádicos com assistente social durante os anos de 2015 e 2016. Retomou acompanhamento para questões psicossociais com terapeuta ocupacional em 2016, o qual foi interrompido em 2017 devido a demissão da profissional e reorganização da equipe.

Em 2017 soube de uma pesquisa com laser para tratamento de pacientes com dor realizada em uma universidade da região, através de um familiar. Iniciou as aplicações voluntariamente e em maio, após quatro aplicações, sofreu uma queimadura na perna esquerda decorrente do uso do laser que, segundo pesquisadores, estava descalibrado. Macuco refere que realizou os cuidados com a ferida em Paideia e após cerca de dez meses o ferimento cicatrizar completamente, entretanto a dor persiste, mais exacerbada sob a região da queimadura. Procurou os médicos de Paideia que solicitaram uma tomografia que aponta que não foi atingido o tecido ósseo, sugerindo a realização de um exame de ressonância magnética para melhor esclarecimento. $O$ serviço que realizou 0 exame sugeriu que Macuco mostrasse os resultados para o médico solicitante para avaliação e conduta.

Atualmente retomou o acompanhamento com psicólogo em Paideia devido a má aceitação do diagnóstico e mantém acompanhamento de acupuntura, o que refere que auxilia muito na redução e controle da dor. Participa também de grupo de alongamento oferecido pelo profissional de educação física e fisioterapeuta do NASF-AB.

Seu filho está internado em uma clínica de recuperação para pessoas que fazem uso abusivo de substâncias ilícitas, o que Macuco refere ter diminuído suas preocupações e ameaças que a família sofria em decorrência de dívidas. Através de uma reunião em uma igreja do bairro, Macuco conheceu voluntárias que realizavam o trabalho de convidar pessoas para a internação em uma clínica. As mesmas conversaram com o filho de Macuco, que participou de palestras em instituições religiosas antes de ser encaminhado. $O$ tratamento do filho termina em 
2018 e seu filho começará a trabalhar na mesma instituição.

Macuco refere realizar atividades domésticas como cozinhar e lavar louça com auxílio das filhas e em ambiente externo, como fazer compras e ir ao banco. A dor se concentra na região da escápula e lateral de braço e perna esquerdos. Refere procurar Paideia ou equipamento de urgência e emergência em momentos de aumento das dores e que, por vezes, passou por investigação de suspeita de infarto agudo do miocárdio devido ao quadro. Nestas situações, referiu que explicou a equipe que a atendeu que sente estas dores desde 2011, porém não obteve boa aceitação.

A figura 9 sintetiza cronologicamente a trajetória do cuidado de Macuco e sua passagem pelos equipamentos de saúde: 


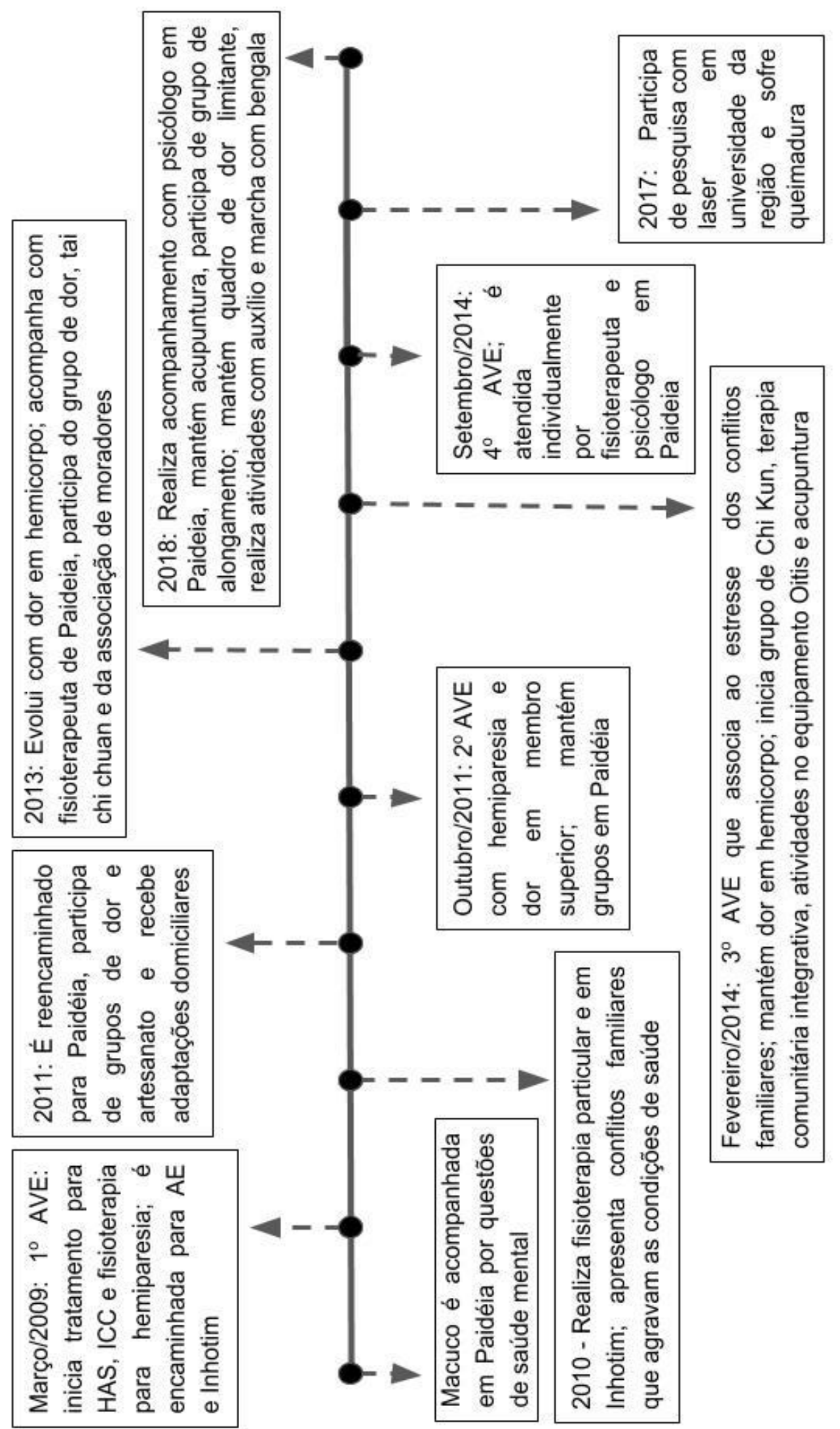

Figura 9: Linha do tempo da trajetória de cuidado da usuária Macuco, 2018. 
O fluxograma a seguir ilustra a trajetória de cuidado de Macuco pela Rede de reabilitação (em destaque). Em azul estão identificadas as entradas nos equipamentos de saúde estudados, em amarelo as ações e atividades que Macuco realiza ou realizou durante seu cuidado e em vermelho aquelas que não foram realizadas ou para as quais Macuco está aguardando. 


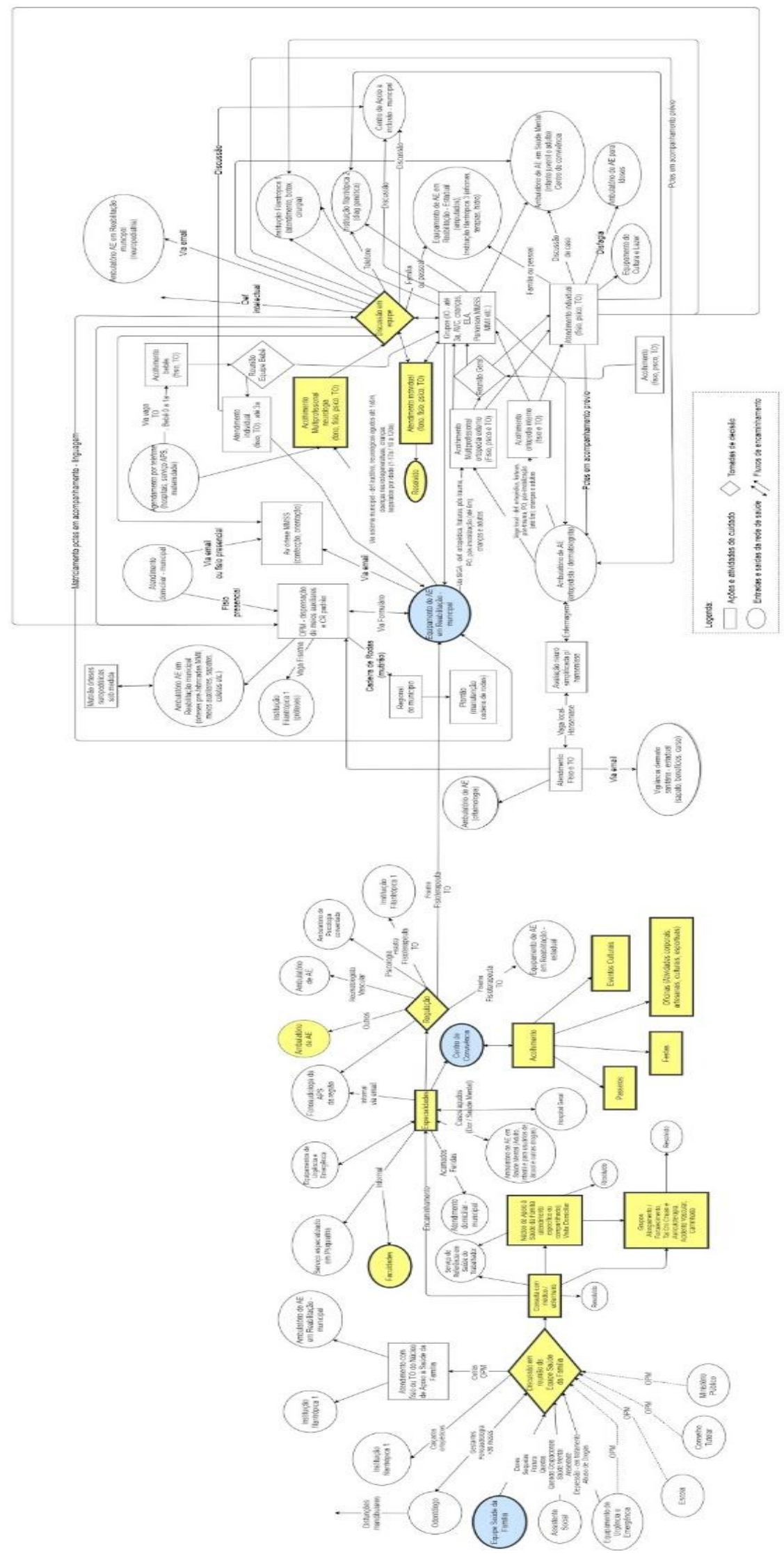

Figura 10: Fluxograma da trajetória de cuidado da usuária Macuco, 2018. 
Durante a entrevista, Macuco relata sua experiência na rede de atenção à reabilitação, detalhando as potencialidades e barreiras. Em relação à dificuldade de aceitação da atual condição de saúde, dadas às limitações na funcionalidade presentes em seu cotidiano e a queixa pouco prevalente, Macuco diz:

"E os médicos falavam assim 'Não é normal paciente de AVC ficar com dores, é muito raro. '

Mas é uma dor muito difícil de controlar, eu acho que eu estaria melhor se não tivesse essa dor porque eu conseguiria fazer mais atividade física. Estes dias mesmo eu tô meia brecada por causa das dores. (...) É difícil de explicar, é do lado todo. "(Macuco)

"E eu ainda tenho uma dificuldade sim, mas é psicológica.

(...) Tá sendo muito difícil de eu aceitar que não pode ser como antes, sabe... eu não consigo trabalhar como antes, eu não consigo andar como antes e então é difícil. E ele (psicólogo de Paideia) falou até pra mim não ficar com isso na cabeça que é normal pacientes não aceitarem assim que deu uma brecada né, que tem que fazer de outro jeito. E tá sendo muito bom passar com ele." (Macuco)

Macuco relata ainda outras experiências positivas nos encontros com os profissionais do equipamento Paideia, ressaltando ainda os aspectos emocionais relacionados a condição de saúde e a importância de estes serem considerados nos atendimentos médicos.

"A gente tá com uma equipe ótima na área (referência da usuária). Uns médicos muito bons assim, sabe... Porque você tá muito mal, com dor, com muita dificuldade e se o médico te 
atende de qualquer jeito você volta mal pra casa... Todos que me atendem são atenciosos, me escutam. Apesar de eu ser repetitiva eles têm paciência e eu fui superando estas dificuldades, assim..." (Macuco)

Sobre as ações e atividades do equipamento Oitis, detalha os grupos dos quais participou, o significado dos mesmos para sua história pessoal e familiar e também para seu processo de cuidado:

"Oitis é um centro de convivência né, dentro do parque... e é muito bom.

(...)

... Porque assim: tudo era proibido, só música sertaneja que meu pai ouvia num radinho. E quando eu fiquei adolescente de 16, 17 anos, pra mim foi um mundo deslumbrante eu descobrir a música. Era época do Jorge Ben, Wilson Simonal, Gal Costa, Caetano... E tudo era proibido, pros meus pais tuo era proibido. Aí em casa pro marido também tudo era proibido. Não pode mexer, não pode dançar, não pode ouvir música né...

E quando eu frequentei bastante tempo o Oitis, tinha um projeto de música, de samba, que eu nunca pensei que eu fosse participar. Eu preciso melhorar destas dores, tomar coragem pra fazer as minhas coisas... me animar, porque agora a situação... É feio até falar isso: o marido que perturbava faleceu, o filho problemático tá se cuidando, vai sair de lá pra um trabalho. O que tá me prendendo ainda a voltar para as atividades são estas dores.

Nossa, eu gostei muito, muito de participar das coisas do Oitis... Ir visitar exposição de artes, que eu pensava que era 
uma coisa tão longe assim, né... É longe do meu universo ir visitar exposição de artes...

E aí tem o Cordão de Carnaval que chama Bibitantan. Eu fiz parte por um tempo! É lógico, eu não dançava porque eu não sambava igual aos outros, mas eu tava aprendendo a tocar um instrumento, o tamborim. " (Macuco)

“(..)

Eu sei que eu tô perdendo uma porção de coisas viu... dentro do Oitis tem uma biblioteca, uns livros que eu gosto de ler e pode pegar emprestado... Tô perdendo um monte de coisas do Oitis! " (Macuco)

“(...)

Nós fomos uma vez com o Oitis fazer um protesto na Avenida Paulista. E a Avenida Paulista, pra gente da periferia também é um negócio lá longe, né... Onde só anda os executivos, quem trabalha lá, né. E nós fomos fazer um protesto lá contra a não internação do serviço psiquiátrico. Foi com o pessoal... como chama... o pessoal do Plantarum. E a gente fez barulho lá, tocou tamborim, o pessoal do Bibitantan foi né... (...) Tem muita coisa interessante do Oitis, muita mesmo. Eu gosto de lá. Preciso me animar pra voltar, sabe..." (Macuco)

Sobre o acesso aos meios auxiliares dos quais necessitou desde o primeiro AVE, Macuco cita apenas o processo que envolveu o andador, no início do quadro, e a bengala, o qual se desdobra até o atual momento. Quando informada sobre a possibilidade de solicitação via Paideia, Macuco refere desconhecer este fluxo.

"Quem me deu a primeira bengala foi o fisioterapeuta do 
Paideia, ele me emprestou um andador do posto. É lógico, eu levantei da cadeira de rodas, mas não sai assim né...

(...) Ele veio várias vezes aqui em casa e me emprestou 0 andador. Eu fiquei um tempo com o andador e quando ele falou 'eu preciso do andador de volta' me deu um medo mas ele falou 'eu vou fazer uma troca, eu levo o andador e te dou uma bengala!'

(...) A que ele me deu não sei o que aconteceu, se ela quebrou, o que aconteceu. Esta fui eu que comprei, mas eu tô achando ela meio pesada assim... eu vi umas mais leves.

(...) Precisa ver altura, eu não sei se eu tô usando ela na altura certa. A que o fisioterapeuta me deu lá atrás ele regulou a altura pra não ficar muito assim (gestos), pra não ficar muito assim né (gestos). Eu também não sei se eu tô usando ela na altura certa não, porque assim, eu comprei esta né, aí achei: ah, tá muito alta. Aí pedi pro marceneiro cortar um pouquinho mas realmente não foi avaliada não. " (Macuco)

Sobre os últimos encaminhamentos e atendimentos realizados em equipamentos de referência para a região, Macuco refere não saber com precisão o tempo dispendido até a consulta com fisiatra, mas aponta que seus desdobramentos foram atendidos e há consonância entre as orientações dos profissionais de Paideia e da AE sobre o manejo de sua queixa principal de dor.

"Eu trouxe pro (Paideia) um pedido de fisioterapia, não me lembro a data. Eu passei num fisiatra no (Equipamento de $A E$ municipal) ... olha, demorou pra sair, acho que foi o doutor anterior do Paideia que tinha feito o pedido pro fisiatra. $E$ perguntei assim várias vezes no Paideia e falou que era pra ter paciência que tem poucos fisiatras na rede pública né. 
Demorou pra sair, eu passei e ele falou que não ia me entupir de remédio porque eu já tomava muitos, que era fisioterapia. Este pedido tá no Paideia... Isso foi muito antes de fazer o acompanhamento com a fisioterapeuta do NASF-AB, muito antes..." (Macuco)

\subsubsection{Usuária Tico-tico}

- Indicação

Tico-tico foi indicada pelo fisioterapeuta e psicóloga do equipamento Batel por apresentar uma condição de saúde pouco frequente e estar na faixa etária de prioridade para atendimento. Ressaltam ainda o contexto familiar no qual a mãe se mostra bastante participativa para os cuidados, entretanto a família apresenta conflitos entre seus membros.

Os profissionais relatam que se trata de uma usuária com um quadro de saúde instável, com episódios de internações recentes e cujo tempo de sobrevida é incerto devido a uma síndrome genética não especificada. Referem ainda que a usuária passa em acompanhamento com fisioterapeuta de Batel e do equipamento de $\mathrm{AH}$ de referência, com dificuldade na comunicação e articulação do cuidado entre ambos.

- Trajetória do cuidado

Tico-tico nasceu em 18 de fevereiro de 2001, pré-termo (idade gestacional 36 semanas e 3 dias), em parto normal sem complicações e após alta hospitalar iniciou acompanhamento na UBS de referência.

Com 1 ano de idade apresentou um episódio de convulsão. Sua mãe relata que pensando retrospectivamente, percebe que a filha já apresentava um pequeno atraso no desenvolvimento, mas na época não se atentou a isto e não foi 
orientada por nenhum profissional de saúde. A família residia em uma região periférica da zona sul na época da convulsão e a mãe relata que foi muito difícil realizar o socorro de Tico-tico. Entrou em contato direto com a pediatra que atendia a filha (de equipamento de $\mathrm{AH}$ na zona oeste) que a orientou levar Ticotico a um hospital terciário especializado em crianças e adolescentes da zona oeste, onde foi atendida e internada para observação. A partir deste momento iniciou o acompanhamento na $\mathrm{AH}$, o qual foi estabelecido como referência para situações de urgência e emergência.

Após alta iniciou acompanhamento com pediatra do equipamento de $\mathrm{AH}$ especializado em crianças e adolescentes, entretanto a mãe não quis medicá-la de imediato. Três meses depois a usuária apresentou novo episódio de convulsão e iniciou medicação e acompanhamento com neurologista de forma ambulatorial no mesmo equipamento. Mantém o acompanhamento no equipamento de $\mathrm{AH}$ especializado em crianças até hoje.

Sobre o desenvolvimento de Tico-tico, a mãe refere que ela andou com 1 ano e 3 meses e começou a se comunicar através de fala, entretanto parou após as crises convulsivas. Mãe percebia que os medicamentos para convulsão causavam muita sonolência e dificultavam a interação de Tico-tico com familiares, porém no momento em que Tico-tico estava acordada apresentava novas crises. Até os dias atuais Tico-tico apresenta irritabilidade para interagir com os irmãos mais novos, segundo a mãe.

Quando era menor (mãe não sabe informar data) realizou acompanhamento de fonoaudiologia, porém interrompeu devido a dificuldades de deslocamento da família. Posteriormente foi encaminhada pela APS a fonoaudiólogo do AE em reabilitação, entretanto finalizou o acompanhamento por não apresentar mais evolução na fala.

Atualmente apresenta comprometimento motor e cognitivo e está em investigação diagnóstica para a hipótese de síndrome genética. Mantém acompanhamento em Batel, com fisioterapeuta (há um ano), pediatra e odontólogo; e sua mãe com psicóloga devido a quadro de ansiedade e dificuldade em compartilhar os cuidados da filha com outras pessoas. Tico-tico e a mãe 
apresentam grande vínculo com o fisioterapeuta de Batel, com melhora do quadro motor relatado pela mãe e da funcionalidade dentro de casa. A mãe ainda elogia a qualidade do cuidado e a competência do profissional de fisioterapia e relata uma tentativa sem sucesso de atendimento de fisioterapia no equipamento de $A E$ em reabilitação estadual.

Segue em acompanhamento ambulatorial no equipamento de $\mathrm{AH}$ especializado em crianças e adolescentes com nutricionista; neurologista e recebe os medicamentos prescritos em casa mensalmente; urologista (devido a quadro de bexiga neurogênica); otorrinolaringologista e fonoaudiólogo para o quadro de disfagia; com fisioterapia respiratória desde a última internação em maio de 2018, inicialmente com frequência semanal e atualmente mensal; com ortopedista com foco em membros inferiores, que já foram submetidos a cirurgia para alinhamento em 2016, entretanto está apresentando desalinhamento novamente; e com pneumologista do equipamento de $\mathrm{AH}$ pois iniciou uso de oxigenoterapia após episódios de internação por pneumonia, descompensação respiratória e realização de exames.

Refere que a equipe de nutrição sugeriu a realização de uma gastrostomia há cerca de um ano devido ao quadro de disfagia e múltiplas internações por pneumonia, porém a mãe recusou a realiza-la por considerar que a filha se alimenta bem, não está perdendo peso e por não querer ver o sofrimento da filha. No mesmo equipamento foi tentado solicitar uma cadeira de rodas, entretanto 0 laboratório de confecção e dispensação foi desativado recentemente.

Relata ainda que no fim de 2017 foi indicada a realização de cirurgia para a correção de escoliose pelos profissionais do $\mathrm{AH}$ especializado em crianças e adolescentes, entretanto, após discussão acerca do procedimento e seus riscos e reavaliação em 2018, os profissionais e a mãe decidiram não realizá-la. Em relação a esta situação, refere conflitos com os profissionais de serviço devido à grande alternância de equipes, erros no encaminhamento interno para solicitação de exames e falhas na comunicação.

O fluxo de solicitação de oxigênio foi feito em 2015 após internação hospitalar, via equipamento de APS e fornecido balão de oxigênio transportado 
por carrinho, o que dificultava o deslocamento de Tico-tico devido ao peso para levá-la. Posteriormente conseguiu balão de oxigênio menor que pode ser acoplado à cadeira de rodas, que Tico-tico também conseguiu este ano através da secretaria de educação após relato da mãe que ela apresentava dificuldade para caminhar em ambiente externo.

Sua última internação hospitalar foi no equipamento de AH em maio de 2018 devido a quadro de infecção respiratória. Nesta situação conheceu outra mãe de uma criança com deficiência que a convidou para participar de um grupo de apoio às famílias de crianças com Síndrome de Down organizado pela sociedade civil

A figura 11 sintetiza cronologicamente a trajetória do cuidado de Tico-tico e sua passagem pelos equipamentos de saúde estudados: 


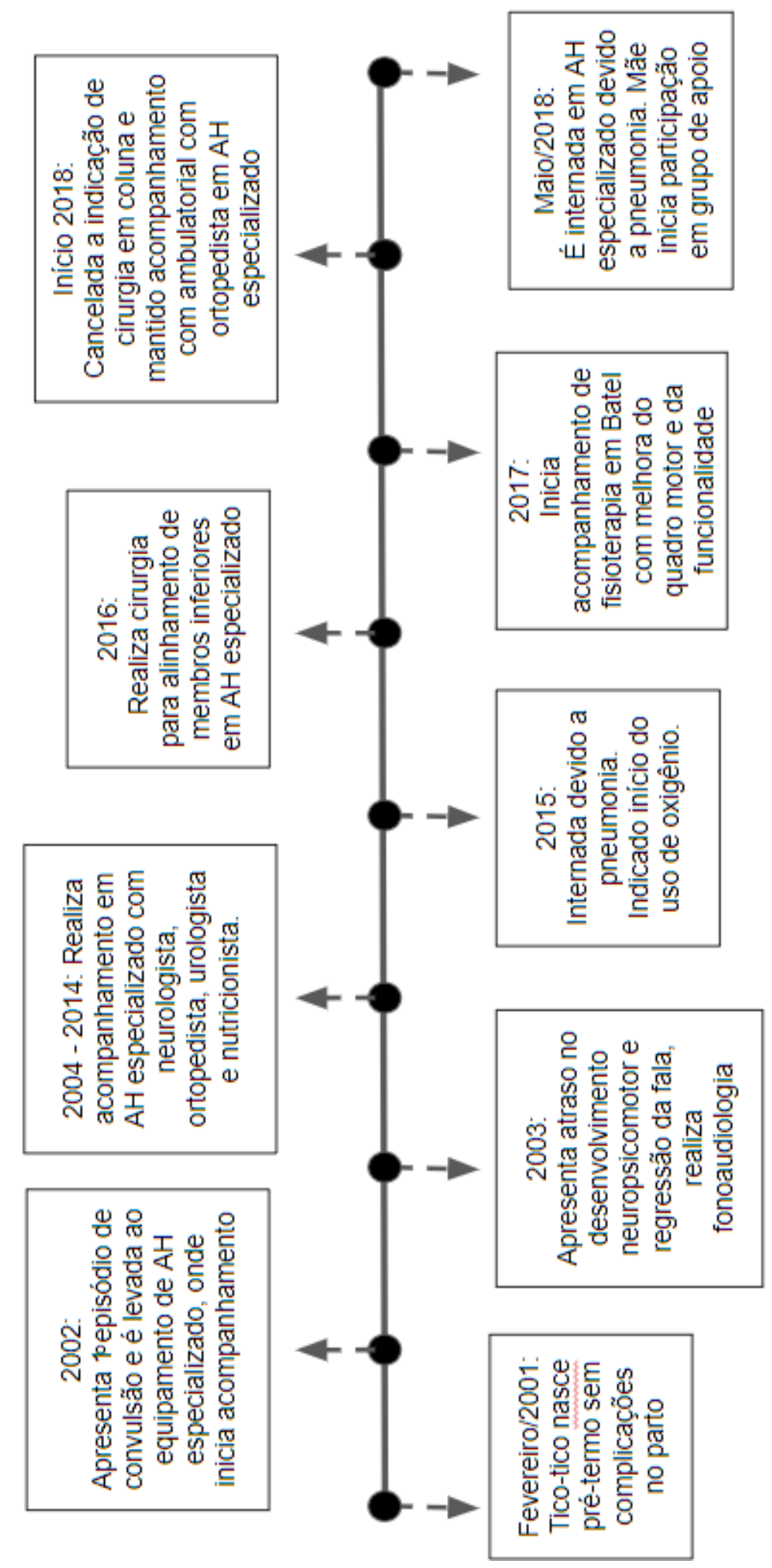

Figura 11: Linha do tempo da trajetória de cuidado da usuária Tico-tico, 2018. 
O fluxograma a seguir (figura 12) ilustra a trajetória de cuidado de Tico-tico pelos equipamentos da Rede de reabilitação estudados.

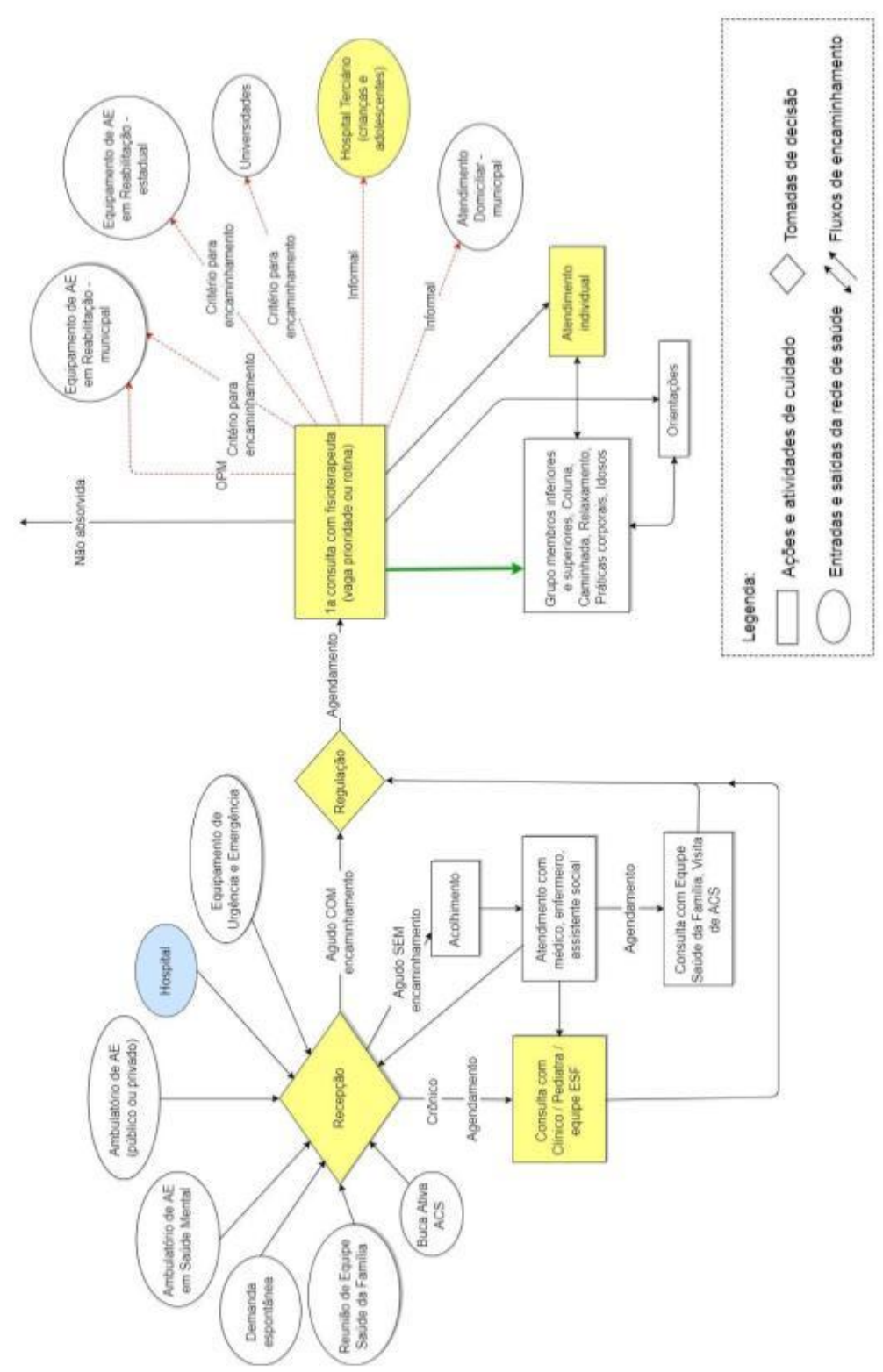

Figura 12: Fluxograma da trajetória de cuidado da usuária Tico-tico, 2018. 
As falas da mãe de Tico-tico trazem relata sua experiência na rede de atenção à reabilitação, detalhando experiências negativas de tentativa de atendimento em reabilitação no equipamento de $A E$ em reabilitação estadual, após encaminhamento de $\mathrm{AH}$ especializado em crianças e adolescentes.

"A pessoa que fez, tipo, a triagem, foi de forma curta e grossa, vamos dizer assim. Em momento algum passou nenhum tipo de sentimento pelo próximo. Tipo assim, ela tava ali exclusivamente para tratar de negócios, vamos dizer assim.

'Mas a sua filha não faz nada, como que eu vou fazer alguma coisa com ela se ela não sabe falar, responder?'

Eu falei assim: Como vocês fazem com um bebê?

Ela ficou sem palavras porque né... eu tô errada? Eu acho assim, se você está num lugar que tem que fazer reabilitação...

'Ela não vai saber repetir'

Eu falei assim: E o que tem a ver uma coisa com a outra? Ela não pode tentar?

(...) Porque ela sabe... Não quer dizer que ela seja incapaz. Ela é incapaz de várias coisas mas não quer dizer que de outras ela também seja, entendeu? Eu fiquei assim em choque e ela falou :

'Ah, vou colocar ela então em uma fila de espera de um pessoal aí pra orientar como você pode estar fazendo alguma coisa com ela em casa'

Se minha filha estivesse dependendo desta pessoa e de algum serviço dali, minha filha, ia morrer seca e não ia ser... Porque até hoje! Já se passaram não sei quantos anos disso." (mãe de Tico-tico)

Refere ainda as barreiras que vivenciou na rede de reabilitação para a 
dispensação de cadeira de rodas:

"A cadeira dela também não consegui por lá (equipamento de $A E$ em reabilitação estadual), consegui pela escola. $A$ escola que forneceu, tanto é que agora que a gente vai tentar trocar, que é o último ano dela também na escola de inclusão que de inclusão não tem nada né... E vamos ver se eu consigo trocar, mas assim... até então chegaram ao ponto de falar que não podiam fazer nada, que no caso dela a gente tinha que tentar de uma outra forma pra conseguir.

(...) Quando eu fui lá a pessoa pegou e falou assim, que num tavam fazendo devido a demanda ser muito grande e eles não tavam tendo mais recurso e o pessoal que tava investindo parou e eles tavam tentando entregar de pessoas que tinham de 4 a 6 anos em fila de espera. (...)

Aí 2 anos atrás eu transferi ela de escola e uma pessoa da (diretoria regional de ensino) que falou 'Não, imagina, aqui nós fornecemos sim'. Porque ela ficou 5 anos em uma outra escola que todo ano falavam que ela ia ter uma cadeira adaptada. Tiravam medida, chamavam fisioterapeuta, fazia isto e aquilo e cadê? Cinco anos a minha filha ficava dormindo no chão, naquelas cadeiras comuns de escola. Imagina pra quem tem problema grave de coluna que nem ela tem a escoliose com cifose e o cóccix dela é totalmente pra fora..." (mãe de Ticotico)

Sobre a qualidade do atendimento e a relação com os profissionais de saúde do equipamento de $\mathrm{AH}$ especializado em crianças e adolescentes, a mãe de Tico-tico exemplifica a partir do contato com os profissionais durante a indicação de necessidade de cirurgia em coluna ocorrido de 2017 ao início de 2018. Fala sobre o acesso aos ortopedistas e a alternância de médicos: 
"Aí os médicos (ortopedista) na triagem falaram 'Não, ela vai fazer acompanhamento aqui'. Só que aí era aquele jogo do empurra empurra. 'Não, ano que vem a gente vai operar, ano que vem, ano que vem...'

E mudavam sempre as turmas, porque cada hora era uma turma que atendia, aí passava um período já vinha outra turma... E nisso, nesse jogo do empurra empurra, os médicos falaram assim, no final do ano passado, comecinho deste. Marcaram uma consulta pra eu levar ela, eu levei. Aí tava tudo certo pra fazer cirurgia, como comentou. Só que ele pegou... não sei se ele foi infeliz no jeito que ele falou...

Ele falou assim 'É... aqui nós fazemos tudo em equipe. Se a equipe falar que sim, que tá tudo bem, perfeito. Vamos correr atrás e fazer as coisas. Se a equipe falar que não então não. A senhora espera um pouco que a gente vai conversar, vamos chamar a equipe, o cirurgião, anestesista... vamos dar uma estudada no caso da sua filha e eu já te dou um breve parecer. Enquanto isso vai lá embaixo onde o pessoal marca pra fazer exame de sangue e depois a senhora volta, que dá tempo' " (mãe de Tico-tico)

Ao ir ao local de agendamento do exame, a mãe de Tico-tico foi informada acerca de um erro no preenchimento da solicitação que a impediria de fazê-la, retornando então para conversar com a equipe que a estava atendendo no dia. $\mathrm{Na}$ fala abaixo relata a reflexão que teve durante este intervalo de tempo, em que estava sozinha. Este relato demonstra as informações que os profissionais do equipamento discutiram com ela no processo de planejamento da cirurgia e como isto a estava impactando emocionalmente. Evidencia também o protagonismo da mãe e sua participação no cuidado de Tico-tico e no processo de decisão para realizar a cirurgia: 
"Era uma decisão muito séria, que corria um risco muito grande dele na hora que entrar na sala de cirurgia falecer. Como ela anda, ela poderia perder os movimentos e era uma cirurgia muito... agressiva demais, sabe, porque eles tinham que abrir na frente, tirar a costela para chegar lá atrás na coluna, iam ter que tirar 5 vértebras.

(...) E caso ela sobrevivesse tinha que rezar pra que ela não pegasse uma infecção muito forte ou então nenhuma porque $o$ risco também poderia ser no pós... Porque além disso ela também ia ter que fazer uma outra cirurgia que seria colocar uns pêndulos com peso pra poder tentar desentortar a coluna, que é outra agressiva também...

E aquilo tudo foi moendo meu coração, sabe... Eu entrei em um desespero porque eu estava sozinha, ela e Deus para tomar aquela decisão! Porque aí eu não tava tendo o apoio de ninguém, nem do pai dela que não quis ir e não tinha ninguém da família, somente eu ali." (mãe de Tico-tico)

Ao ser atendida novamente pelo ortopedista, irritou-se com a incoerência na fala do profissional e indicou isto a ele:

"O médico chamou os outros médicos e disse 'Olha, mãe, é o seguinte: o caso da sua filha é de extrema gravidade, a coluna dela está muito torta... (...) A gente não tem mais o que falar pra você pra você a respeito dos perigos porque ela não tem peso, ela não tem estrutura e esta cirurgia, além de ser agressiva, ela é muito muito arriscada mesmo. O pessoal acha melhor que não. Só que eu acho que eu por mim tentaria.'

Aí eu olhei pra cara dele e falei assim 'Bom, então você não tem palavra porque há alguns minutos atrás você falou pra 
mim que é tudo feito em equipe. Se você fala uma coisa e todo mundo falou outra então acabou ali. Não tem depois. Como que você chega em mim e fala que gostaria de tentar?

\section{(...) E se ela ficar alejada?}

Eu só quero que vocês acompanhem a vidinha dela mas eu não vou mais mexer com isso porque eu acho que isso vai prejudicar mais, entendeu. E como a gente acostumou com ela assim então deixa assim mesmo."' (mãe de Tico-tico)

A partir de então Tico-tico realiza acompanhamento ambulatorial no equipamento de $\mathrm{AH}$ especializado em crianças e adolescentes com ortopedista.

Sobre a recente entrada e participação no grupo de apoio para famílias de crianças com Síndrome de Down, para a qual foi convidada, a mãe de Tico-tico relata a importância do mesmo e seu papel como apoio emocional e troca de experiências com outras pessoas:

"A gente participa de vários grupos de mães de especiais, né... E ela foi abençoada também, porque tem um grupo de mães de downzinhos (pacientes com Síndrome de Down) que adotou ela e mais dois irmãozinhos gêmeos que têm paralisia cerebral...

A gente tem um grupo de troca, a gente conversa. Tem um grupo só pra gente desabafar, falar bobeira... tem hora que fica bravo com alguma coisa que aconteceu ou se revolta e a gente acaba desabafando no grupo.

Então a gente tem vários relatos, né. E da semana passada pra essa já faleceram duas crianças, então a gente já fica com o coração partido porque a gente não sabe o que tava acontecendo, não sei qual o tipo de síndrome ou se tinha alguma coisa a criança, pra ter falecido...

(...) A gente acaba se apegando com as mulheres..." (mãe de 
Tico-tico)

Conta ainda sobre articulações práticas para como fonte de informações, equipamentos e insumos para o cuidado das crianças, muitas vezes em falta ou não fornecido pela rede formal de cuidado.

"Tanto é que sexta-feira eu vou até pegar um aspirador de uma que perdeu um filho. Ela falou que se ela pudesse ela até doaria, mas ela vai vender por um preço simbólico este aparelho de aspirar que tá na faixa de uns 300 a 400 reais...

(...) O preço que eu tô dando pra ela, ela não vai se desfazer do aparelho de qualquer jeito e ela também vai poder estar comprando com este dinheirinho alguma coisa que ela precisa, né... Porque fica difícil..." (mãe de Tico-tico)

"Tem gente que faz troca de medicação porque tem umas que não conseguem, que o próprio hospital tá em falta, mas algumas tem ciência. Remédios de uns nomes que eu nem conheço! Tipo assim: lógico que não é qualquer remédio.... Você tem que mostrar a receita de que precisa e tudo bem, faz a troca.

Dela eu trocava produtos de higiene... mais é simbólico, mas só o fato de que você não vai precisar pagar e tem alguma coisa pra ofertar..." (mãe de Tico-tico) 


\subsection{Demandas de reabilitação atendidas e reprimidas para a atenção especializada}

A constituição da amostra dos encaminhamentos de reabilitação para a Atenção Especializada está exposta na figura 13.

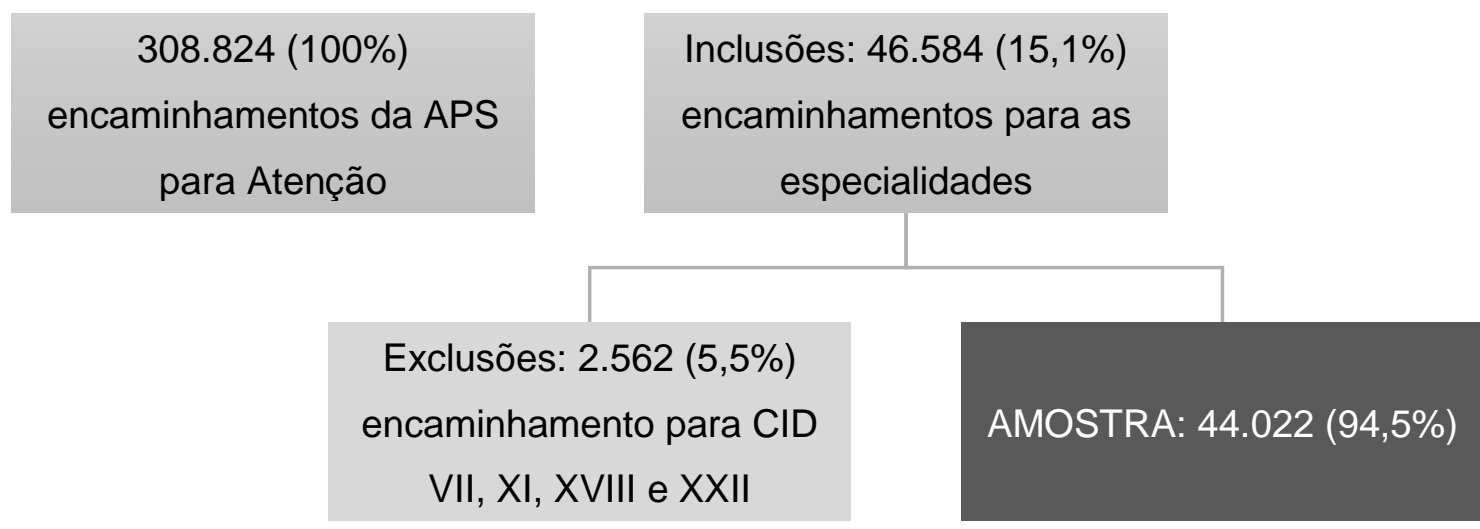

Figura 13: Fluxo de encaminhamentos de demandas de reabilitação da APS para atenção especializada, 2012 a 2016.

A Tabela 1 mostra a característica da fila de espera para a atenção especializada de reabilitação municipal. $\mathrm{Na}$ amostra estudada, a média das idades dos usuários que aguardavam na lista de espera durante o período de 2012 a 2016 foi de 47,1 anos ( $\mathrm{DP}=22,5$ ) e a mediana de 51 anos (idade mínima $=0$ anos; idade máxima = 102 anos). O município de São Paulo constava como local de residência em 43.265 encaminhamentos (98,95\%) e outros 38 municípios apresentavam, conjuntamente, 464 encaminhamentos (1,05\%).

Em relação à quantidade de acometimentos classificados pela CID, 43.642 $(96,2 \%)$ apresentavam uma classificação, $1.491(3,4 \%)$ duas e $170(0,4 \%)$ três classificações diferentes. Entre os equipamentos de saúde, por nível de atenção, os que mais concentravam encaminhamentos foram: dos equipamentos mistos, o 
número 3 com 6.058 (13,76\%) seguido do 2 com 4.246 (9,65); dos equipamentos de APS, o de número 19 com 4.864 (11,05\%); e dos equipamentos da Atenção Especializada o de número 4 com 4.113 (9,34\%). Os equipamentos 28 da Atenção Especializada, 21 e 27 da APS apresentaram a menor quantidade de encaminhamentos, sendo respectivamente 254 (0,58\%), 780 (1,77\%) e 785 $(1,78 \%)$.

Considerando-se as especialidades profissionais analisadas, as com maior quantidade de encaminhamentos foram as especialidades médicas com 29.963 (68,06\%) encaminhamentos; fisioterapia com 9.452 (21,47\%); fonoaudiologia com 1.875 (4,26\%); e acupuntura com 1.578 (3,58\%). Constavam ainda encaminhamentos para Avaliadores de Órteses, Próteses e Meios Auxiliares de Locomoção, Cirurgia ortopédica, Especialista em Reabilitação Física, Odontologia para pessoas com deficiência, Psicologia e Terapia Ocupacional, especificados na tabela 1.

Vale destacar que os resultados têm como base a lista de encaminhamentos disponibilizada pela gestão municipal, entretanto é de conhecimento do grupo de pesquisadores que existem listas internas em alguns equipamentos de saúde da região, dados que serão coletados.

Tabela 1: Distribuição dos encaminhamentos com demanda de reabilitação para a atenção especializada, 2012 a 2016.

\section{Característica da fila de espera para a atenção especializada de reabilitação}

n (\%)*

Equipamentos de saúde

Atenção Primária à Saúde

$26.942(61,2)$

Misto (Atenção Primária à Saúde e Urgência e $12.713(28,8)$ Emergência) 
Atenção Especializada

4.367 (10)

\section{Especialidades*}

\begin{tabular}{|c|c|}
\hline Ortopedia & $16.691(37,92)$ \\
\hline Fisioterapia & $9.452 \quad(21,47)$ \\
\hline Pneumologia & $5.723 \quad(13,00)$ \\
\hline Neurologia & $4.061 \quad(9,22)$ \\
\hline Psiquiatria & $2.547 \quad(5,79)$ \\
\hline Acupuntura & $1.578 \quad(3,58)$ \\
\hline Fonoaudiologia & $1.162(2,64)$ \\
\hline Fonoaudiologia - audiologia & $713 \quad(1,62)$ \\
\hline Reumatologia & $608 \quad(1,38)$ \\
\hline Psicologia & $602 \quad(1,37)$ \\
\hline $\begin{array}{l}\text { Avaliador de Órteses, Próteses e Meios auxiliares de } \\
\text { locomoção }\end{array}$ & $(0,75)$ \\
\hline Fisiatria & $152(0,35)$ \\
\hline Terapia Ocupacional & $150 \quad(0,34)$ \\
\hline Geriatria & $131 \quad(0,30)$ \\
\hline Especialista em reabilitação física & $(0,08)$ \\
\hline Genetica clinica & $31 \quad(0,07)$ \\
\hline
\end{tabular}




\begin{tabular}{l|cc|}
\hline Cirurgia Ortopedica & 28 & $(0,06)$ \\
\hline Neurocirurgia & 18 & $(0,04)$ \\
\hline Odontologia - Pessoas com deficiência & 7 & $(0,02)$ \\
\hline Hansenologia & 1 & $(0,00)$ \\
\hline
\end{tabular}

\section{Capítulos CID - 10**}

\begin{tabular}{l|c|}
\hline $\begin{array}{l}\text { XIII Doenças do sistema osteomuscular e do tecido } \\
\text { conjuntivo }\end{array}$ & $25.320(55,9)$ \\
\hline X Doenças do aparelho respiratório & $5.410 \quad(11,9)$ \\
\hline V Transtornos mentais e comportamentais & $4.379(9,7)$ \\
\hline VI Doenças do sistema nervoso & $3.985(8,8)$ \\
\hline XIX Lesões, envenenamento e algumas outras & $1.928 \quad(4,3)$ \\
consequências de causas externas & $1.288 \quad(2,8)$ \\
\hline XXI Fatores que influenciam o estado de saúde e o \\
contato com os serviços de saúde
\end{tabular}




\begin{tabular}{l|c|}
\hline II Neoplasias (tumores) & $97(0,2)$ \\
\hline XVI Algumas afecções originadas no período perinatal & $66(0,1)$ \\
\hline XII Doenças da pele e do tecido subcutâneo & $63(0,1)$ \\
\hline XIV Doenças do aparelho geniturinário & $59(0,1)$ \\
\hline XX Causas externas de morbidade e de mortalidade & $29(0,1)$ \\
\hline $\begin{array}{l}\text { III Doenças do sangue e dos órgãos hematopoiéticos e } \\
\text { alguns transtornos imunitários }\end{array}$ & $23(0,1)$ \\
\hline XV Gravidez, parto e puerpério & $5(0,0)$ \\
\hline
\end{tabular}

\section{Procedimento solicitado}

\begin{tabular}{l|c|}
\hline Consulta & $38.947(88,5)$ \\
\hline Exame & $4.047(9,2)$ \\
\hline Avaliação & $717(1,6)$ \\
\hline Órteses, Próteses e Meios Auxiliares de Locomoção & $311(0,7)$ \\
\hline
\end{tabular}

\section{Tipo de Atendimento}

\begin{tabular}{l|c|}
\hline Primeira vez & $43.110(97,9)$ \\
\hline Retorno & $912 \quad(2,1)$ \\
\hline
\end{tabular}

\section{Prioridade}

\begin{tabular}{l|l} 
Média & $29.316(66,6)$ \\
\hline Alta & $14.133(32,1)$
\end{tabular}


Baixa

Status

\begin{tabular}{l|c}
\hline Inativo & $39.692(90,2)$ \\
\hline Ativo & $4.330(9,8)$ \\
\hline
\end{tabular}

*Devido a especificidade dos resultados, foram adotadas duas casas decimais.

**Foram somadas as classificações de acometimentos.

${ }^{\star * *} O$ total de encaminhamentos para o serviço especializado é diferente em função da ausência de respostas. 


\section{DISCUSSÃO}

Ao dar voz aos diferentes atores da Rede de Atenção à Reabilitação, usuários e profissionais, o estudo propiciou a elaboração de um panorama ampliado acerca da oferta, qualidade e gestão do cuidado oferecido na região, de modo a compor um repertório de possibilidades de organização dos fluxos estabelecidos. A visão dos pesquisadores contribuiu para esta composição a medida em que possibilitou a análise de um elemento externo ao equipamento que ao mesmo tempo compartilha das reflexões sobre a práxis da reabilitação e se identifica no discurso dos profissionais.

Durante a realização do estudo pôde-se perceber o estímulo à reflexão dos profissionais sobre os processos de trabalho internos aos equipamentos de saúde e sobre a articulação com os demais equipamentos, identificando os desafios do trabalho vivo e as estratégias potentes para responder às demandas e necessidades de saúde da população.

O auto relato das trajetórias de cuidado pelas usuárias, muitas vezes confundida com as histórias de vida das próprias e de suas famílias, demonstrou o protagonismo dos sujeitos na busca pelo cuidado em saúde, confrontando a o estabelecimento de relações verticais estabelecidas com os profissionais da saúde. Observou-se interessantemente as afetações que o estudo causou nas usuárias entrevistadas, de modo positivo ao estimular a reflexão e retomada dos caminhos e atividades previamente realizadas que impactaram em sua saúde; e por vezes negativo, ao reviver situações e experiências desconfortáveis no contato com profissionais e equipamentos de saúde.

Nos equipamentos de APS observou-se um contato inicial híbrido de atividades de cuidado individual como atendimentos pelos profissionais designados, normalmente com necessidade de agendamento; com o acolhimento, relatado como forma de cuidado para queixas agudas ou urgentes. $\mathrm{O}$ acolhimento se mostrou como atividade desencadeadora de outras ações de cuidado internas a todos os equipamentos, exceto em Paideia em que é inexistente, e inclusão dos usuários nos fluxos de acompanhamento das necessidades e demandas de 
reabilitação.

Nos equipamentos de $\mathrm{AE}$ analisados observou-se o acolhimento como forma de contato inicial com os profissionais, seja de forma previamente agendada, como em Inhotim, ou sem necessidade de agendamento prévio como em Oitis e Plantarum. O estudo de Mitre (2013) elucida os desafios na implementação do acolhimento em equipamentos de $\mathrm{AE}$ devido a manutenção da abordagem pautada no modelo biomédico hegemônica, com foco na doença e incapacidade dos usuários. Estas considerações repercutem na fragmentação do cuidado dos usuários, marcada pela estratificação das queixas, o que se faz presente também nos dados referentes aos encaminhamentos da rede de reabilitação do Butantã, classificados a partir de capítulos da CID-10.

Tal postura dos profissionais de saúde minimizam as possibilidades de participação dos usuários em seu processo de cuidado ao ser adotada linguagem técnica, pauta que será aprofundada mais adiante.

O reconhecimento inicial das necessidades e demandas dos usuários, no que tange à reabilitação, é realizado por profissionais da equipe administrativa em Batel e Ubirajara, e logo direcionado às atividades internas de cuidado, sendo que no último é feito por profissionais da equipe de saúde se o usuário residir no território da ESF. Em Paideia, Inhotim, Oitis e Plantarum este reconhecimento é feito exclusivamente por profissionais de saúde.

Os momentos de tomada de decisão em reunião de equipe para determinar o plano de cuidado, PTS ou plano terapêutico, estão presentes nos equipamentos de APS Paideia e Ubirajara e ausente em Batel o que sugere que este constitui um fator independente do modelo tecnoassistencial de organização, embora a realização de discussão de casos e construção conjunta de PTS seja uma atribuição da APS conforme a PNAB (Brasil, 2017). Em 2017, Rodes et al. realizaram um estudo que buscou conhecer e refletir sobre as experiência de fisioterapeutas, fonoaudiólogos e terapeutas ocupacionais atuantes na APS com a elaboração de PTS. Constatou-se que estes profissionais apresentam dificuldades na implementação desta ferramenta devido a multiplicidade de concepções teóricas e dificuldades da organização em equipe para a prática da mesma, 
entretanto relatam a ampliação do olhar para este cuidado eo entrar em contato com o PTS. Quando construídos o PTS, os profissionais relatam dificuldade em concretizar as ações longitudinalmente devido a ausência de registro formal.

Nos equipamentos da $\mathrm{AE}$, Inhotim apresenta a reunião de equipe em subgrupos (reunião da equipe de bebês, reunião geral para discussão de casos de perfil ortopédico e reunião da equipe para usuários com perfil neurológico) para a elaboração do PTS dos usuários e determinação de novas propostas de cuidado internas e externas ao equipamento, assim como em Plantarum. Ambos demonstram a possibilidade de rediscussão e reavaliação dos cuidados ofertados no decorrer do processo de cuidado dos usuários assistidos. Em Oitis esta decisão é tomada diretamente após o acolhimento e direcionamento para as atividades de cuidado, feita por um profissional de referência que será responsável pelo acompanhamento do usuário.

O trabalho em equipe se mostra como fator significativo nas práticas de saúde dos equipamentos em questão, com destaque para Inhotim, no qual observamos ações de cuidado oferecidas pela equipe de profissionais no acolhimento, abordagens coletivas e nas reuniões para discussão de casos e elaboração de PTS. O trabalho em equipe constitui em um modo de debruçar múltiplos olhares sob o usuários a ser estudado e, a partir do compartilhamento das diferentes concepções e estratégias de cuidado sugeridas, busca a efetivação do cuidado integral. Uchoa (2012) chama a atenção para o manejo do trabalho em equipe a fim de evitar a simples sobreposição dos olhares dos profissionais envolvidos, abrindo mão da integração entre os mesmos, achado comum nos serviços de reabilitação.

As ações de cuidados coletivos se mostraram presentes em todos os equipamentos analisados, apresentando uma diversidade de oferta e se constituindo como elementos potentes para o cuidado nos três equipamentos de APS, seja segundo os profissionais (em Batel e Ubirajara) ou os pesquisadores (em Batel, Paideia e Ubirajara).

No relato das usuárias estão expressas as dificuldades de acesso aos equipamentos de $\mathrm{AE}$ através dos fluxos estabelecidos, o período de espera 
prolongado para atendimentos pontuais, bem como para os equipamentos de $\mathrm{AE}$ em reabilitação para processos terapêuticos prolongados, como os que Andorinha, Macuco e Tico-tico necessitam ou necessitaram em algum momento de sua trajetória. Macuco ressalta que apenas o equipamento Oitis não impôs esta dificuldade de acesso, o que pode ser atribuído a organização de recebimento da demanda espontânea sem necessidade de agendamento prévio.

Os dados quantitativos, entretanto, não representam tais dificuldades, tendo em vista que segundo eles apenas $9,8 \%$ dos encaminhamentos encontram-se ativos, ou seja, estão em fila de espera para atendimento. Os outros $90,2 \%$ dos encaminhamentos aparecem como inativos, muito embora não sejam referidas as justificativas pelos quais foram inativados, que podem ser atribuídas a absenteísmo, tempo de espera prolongado (há mais de seis meses, conforme diretriz municipal em vigor desde 2016), mudança do usuário para outros territórios ou impossibilidade de agendamento por falhas de comunicação (mudança de contato telefônico, por exemplo).

Em relação à resolutividade das ações e atividades internas aos equipamentos de APS, Paideia demonstrou que tanto os cuidados individuais quanto os coletivos apresentam resolutividade para as necessidades e demandas de reabilitação dos usuários, evidenciando três das quatro ações de cuidado em reabilitação oferecidas no equipamento. Ubirajara indicou a presença de resolutividade em ações que vão desde o acolhimento inicial até ações de cuidado individual no equipamento, ações de cuidado individual em visitas domiciliares e em ações coletivas. Em Batel não foram relatadas ações e atividades que apresentaram resolutividade para as questões de saúde, o que pode ser devido a oferta restrita de ações e atividades para atender à população, que desembocam nas ações do profissional de fisioterapia em todos os casos.

Os profissionais dos equipamentos de $A E$ não identificaram atividades ou ações resolutivas em seus fluxos, entretanto os três identificaram vias de retorno para os equipamentos que inicialmente realizaram o encaminhamento, o que pode sugerir a compreensão da longitudinalidade do acompanhamento nos equipamentos de APS de referência em contraste com a assistência por período 
determinado na $\mathrm{AE}$.

Nas falas das usuárias entrevistadas foi identificada a resolutividade de ações nos equipamentos de $\mathrm{AE}$, como no atendimento de fisiatria para Macuco que endossou a conduta da equipe da APS para o manejo da dor e na cirurgia de Andorinha na instituição filantrópica 1 , que se desdobrou para a reabilitação de pós operatório e posterior alta para o acompanhamento anteriormente realizado. Os dados quantitativos inferem a resolutividade dos encaminhamentos para a $A E$, apresentando que $97,9 \%$ dos encaminhamentos são para atendimento iniciais (primeira vez) e apenas 2,1\% para consultas de retorno na $\mathrm{AE}$.

A relação entre os equipamentos de saúde foi abordada nos grupos de discussão com o intuito de analisar a articulação entre os mesmos e seu papel como potencializador ou barreira para o cuidado em saúde. Ficaram explicitas em Plantarum as articulações para discussão de casos e encaminhamentos para outros equipamentos de saúde e intersetoriais como etapa indispensável do fluxo estabelecido, em caráter de neutralidade em relação aos seus impactos no cuidado. Plantarum foi citado por quatro dos outros cinco equipamentos como um articulador para o cuidado, sendo identificado como potencializador em Ubirajara.

Inhotim menciona a articulação com cinco equipamentos da rede de reabilitação, a partir de estratégias para discussão acerca do cuidado de usuários, reforçando Oitis e Plantarum como equipamentos que possibilitam este diálogo e integração dos cuidados. Oitis não explicita as estratégias de articulação com os demais equipamentos da rede, muito embora indique a via de articulação com quatro dos onze equipamentos dos quais recebe encaminhamentos.

Nos equipamentos de APS as barreiras para a articulação da rede se mostraram mais evidentes. Paideia descreve fluxos unidirecionais de encaminhamento, com exceção dos equipamentos Plantarum, da $\mathrm{AE}$ em saúde mental infanto-juvenil e de urgência e emergência. Das quinze vias de encaminhamento para outros equipamentos de saúde e intersetoriais, nove são identificados como barreiras (quatro pelos profissionais e seis pelos pesquisadores). O equipamento Batel relata que as articulações com outros equipamentos se apresentam como barreiras para o cuidado, sejam elas por vias 
formais ou informais, o que é identificado pelos profissionais e pelos pesquisadores dada a determinação de critérios restritos para o acesso dos equipamentos de reabilitação estadual e a reduzida disponibilidade de vagas para encaminhamento para o equipamento de $A E$ em reabilitação municipal. Além disso duas das demais vias são dependentes do conhecimento do profissional que atua no equipamento de saúde, não se apresentando como possibilidade aberta aos demais atores.

Já Ubirajara cita articulações com todos os equipamentos para os quais realiza encaminhamentos, o que é inferido pela presença de setas bidirecionais, atribuindo a três deles características de potencializador (para Plantarum, AE para usuários de álcool e outras drogas e ambulatório de saúde indígena) e para os demais (14 equipamentos identificados) característica de barreiras para o cuidado dos usuários tanto pelos profissionais quanto pelos pesquisadores.

A rede de cuidados informais se faz fortemente presente nas falas das usuárias, embora haja direcionamento dos profissionais dos equipamentos de saúde para atividades e outros serviços. Inicialmente Macuco e seus familiares acionam contatos pessoais em busca de atendimentos de fisioterapia particular, dada a dificuldade de locomoção da usuária e de deslocamento via transporte público para o equipamento Inhotim. Em seguida, Macuco é motivada pela percepção de esgotamento das possibilidades de cuidado que contribuem para a amenização de sua queixa principal, buscando iniciativas experimentais em grupos de pesquisa e sendo direcionada a outras alternativas de atendimentos de acupuntura pelo profissional de Paideia. Concomitantemente a isto, Macuco auxilia no processo de cuidado de seu filho através da articulação com uma instituição religiosa e intermediação de pessoas da comunidade na comunicação com seu filho.

A mãe de Andorinha, após a inserção em grupo de Inhotim e diante a vivência de longo tempo de espera para aquisição de cadeira de rodas adaptada para sua filha, vislumbra na relação interpessoal com mães de outras crianças a possibilidade de conseguir o meio auxiliar de locomoção em questão. No relato da mãe de Tico-tico é ressaltada a importância da organização de entidades civis na 
rede de apoio social para familiares de crianças com acometimentos de saúde pouco frequentes, no que tange à troca de experiências de cuidado, acesso a serviços de investigação diagnóstica, indicação de medicamentos e terapêuticas.

Outra rede informal acionada pelas usuárias Andorinha e Tico-tico é via secretaria municipal de saúde em relação a indicação, prescrição e dispensação de cadeiras de rodas adaptada. Nos fluxogramas dos equipamentos de APS e em Inhotim o fluxo de cadeiras de rodas e outras OPM aparecem como barreiras para o cuidado por via formal entre os equipamentos de saúde. A via através das escolas que as usuárias frequentam se mostra mais eficiente nas falas de ambas, apesar do relato de tempo de espera prolongado, mas ainda menor do que a via formal.

O relato dos profissionais sobre as redes informais de cuidado demonstra que a impossibilidade da rede formal atender às demandas e necessidades dos usuários por: inexistência da oferta de cuidados na rede, dificuldade no deslocamento dos usuários, ou por grande intervalo de tempo de espera para o acesso às ações de cuidado. Os profissionais buscam então, alternativas que são atribuídas à vivência pessoal nos equipamentos de saúde e territórios, e à iniciativa e capacidade de articulação próprias para colaborar com o cuidado dos usuários.

Neste estudo foi possível observar os movimentos invisíveis da população descritos por Acioli (2009) a partir do relato das usuárias e de suas vivências. Esta rede de movimentos, consequente desdobramento das experiências do processo saúde-doença, surge como estratégia de enfrentamento da população a seus problemas de saúde e seu reconhecimento colabora para a avaliação dos profissionais acerca das possibilidades das redes informais e da efetividade de suas condutas e orientações.

A participação ativa no processo de cuidado e a autonomia dos sujeitos estão presentes nas falas das usuárias acerca da busca pelas atividades de cuidado, da insatisfação com a oferta de ações e com as barreiras encontradas nos equipamentos de saúde e da escolha de participar das atividades propostas pelos profissionais de saúde de Paideia, no caso de Macuco. 
Para Fortes e Zoboli (2004) faz-se necessário oportunizar às pessoas medidas para que conquistem a autonomia necessária sobre suas condições de vida e de saúde, atingindo o controle das tomadas de decisão em ações que as afetam. Para tanto é importante considerar a informação como ponto crucial para esta tomada de decisão, que pode ser proveniente dos profissionais de saúde a partir do esclarecimento sobre os acometimentos de saúde, prognósticos, tratamentos e alternativas terapêuticas (Cavalcanti, 2015). Considera-se como característica do trabalho na APS o estímulo ao desenvolvimento da autonomia dos usuários e da construção compartilhada do processo de cuidado, incluindo as ações de reabilitação (Brasil, 2017), o que corrobora com a fala de Macuco acerca da qualidade da atenção prestada pelos profissionais da equipe e da abertura para a escuta e o diálogo.

As relações entre os profissionais de saúde e os usuários se dão a partir do encontro de duas percepções diferentes sobre das necessidades e demandas de saúde, como denominam os primeiros, ou do que acontece com o corpo vivido pelos segundos. Este descompasso entre a percepção dos profissionais e dos usuários acerca do seu processo saúde-doença provém da coexistência de dois saberes: o saber biomédico e o saber popular (Le Breton, 2012).

Cada um destes grupos carrega seus próprios modos de ser, referenciais, conhecimentos, experiências e expectativas em relação a si e ao processo de cuidado. Por um lado, temos o primeiro, socialmente reconhecido como detentor do conhecimento técnico-científico ou acadêmico e que por vezes centraliza o poder de legislar sobre o fazer saúde. Por outro temos a experiência dos impactos da doença e da saúde vivenciados cotidianamente pelos usuários, em seus corpos e mentes. Observa-se, portanto, um paradoxo importante para a tomada de decisão no processo de cuidado, tendo em vista que se os usuários são os proprietários de seus corpos e os profissionais de saúde são:

(...) a figura 'proprietária' social e legalmente autorizada para agir em situações e momentos em que há uma necessidade de intervenção no corpo do indivíduo em decorrência da 
doença ou da falta de saúde (Cavalcanti, 2015)

Para dissolver este impasse são necessários movimentos de aproximação e diálogo entre profissionais e usuários dos equipamentos de saúde de APS e AE, que busquem a criação de vínculos e a construção de processos de cuidado compartilhados. Para Coelho (2009) o uso de tecnologias como a humanização e o acolhimento flexibilizam e horizontalizam os saberes gerando a possibilidade de criação de novos modos de cuidado direcionado às especificidades do contexto no qual cada sujeito está imerso. Merhy (2006) afirma que o uso das tecnologias leves ou relacionais descritas se mostra interessante para a produção das interações entre os sujeitos que se afetam mutuamente, diferentemente da percepção de atuação dos profissionais de saúde tendo o usuário como objeto. O mesmo elucida esta diferença através da imagem de um marceneiro que confecciona uma cadeira e a entrega a um usuário, em contraposição ao encontro entre o profissional de saúde e o usuário que juntos compartilham da produção do cuidado visando a contribuir positivamente para as condições de saúde.

Os relatos dos profissionais para indicação de usuárias, bem como as falas das usuárias, demonstram a interação positiva entre estes dois atores que vivenciam diversos encontros em períodos prolongados, seja na APS ou na $A E$, dada a complexidade das situações de saúde apresentadas. As dificuldades na interação relatadas pelas usuárias se referem a profissionais de equipamentos de saúde mais distantes da realidade dos territórios, normalmente representativos de referências municipais.

Sendo assim, no processo de cuidado em saúde o profissional e o usuário elaboram um espaço de intersecção de um sobre o outro, sendo os dois ativos ao incorporarem suas perspectivas e estabelecerem relações mobilizadoras de afetos. O processo de cuidado deixa de ser, então, uma atribuição exclusiva dos profissionais de saúde e se torna um fazer compartilhado com maior potência.

As dificuldades inerentes ao estudo se deram devido à ausência de referenciais bibliográficos que adotaram metodologia similar para compreender a gestão do cuidado em reabilitação no âmbito do Sistema Único de Saúde. Os 
estudos encontrados, que tiveram grande colaboração nesta dissertação, investigaram as repercussões das trajetórias de cuidado e fluxos organizacionais dos equipamentos de saúde no contexto da rede de atenção psicossocial e das situações relacionadas a violência contra a mulher. 


\section{CONCLUSÕES}

Ao identificar e analisar as formas de organização interna dos equipamentos de saúde pôde-se observar a diversidade de oferta de ações e atividades e de arranjos organizacionais no fluxo de inserção e direcionamento interno. Notou-se a existência de ofertas comuns de cuidados nos equipamentos de saúde estudados, com repercussões menores da variabilidade que poderia ser atribuída ao seu nível de atenção. Evidenciou-se ainda o impacto das estratégias individuais e dos conhecimentos dos profissionais atuantes na rede na determinação das ações oferecidas pela APS, devido à ausência de diretrizes mais explícitas para a operacionalização do processo de trabalho em reabilitação. Os modelos tecnoassistenciais adotados pelos equipamentos de APS não demonstraram ter impactos determinantes na oferta de atividades ou no acesso aos equipamentos em questão.

A análise dos fluxos entre os equipamentos de saúde demonstrou a inexistência de equipamentos de referência para algumas das necessidades dos usuários e dificuldades na articulação entre a rede. Evidenciou-se o desconhecimento acerca dos fluxos e das atribuições dos demais equipamentos de saúde, limitada à ciência dos critérios de inclusão. Notou-se também a existência de redes informais de conhecimento dos usuários e profissionais de saúde, que exercem papel importante associado às redes formais no sentido de agilizar e ampliar as possibilidades de resposta às demandas e necessidades de saúde. Considera-se interessante verificar mais a fundo eventuais pontos informais de oferta de atividades e o papel que estes desempenham no cuidado dos usuários.

As dificuldades de acesso aos equipamentos de $A E$ específicos ou não para reabilitação, sejam municipais ou estaduais, e às instituições filantrópicas que oferecem ações e atividades de cuidado via convênio com o município, associada ao relato das usuárias demostraram a baixa disponibilidade da oferta de cuidado. Os dados quantitativos, por outro lado, representam uma resposta adequada às necessidades de encaminhamento para os equipamentos de $A E$, entretanto não 
elucidam os critérios para classificar o encaminhamento como ativo ou inativo. Estes mesmos dados apresentam expressiva quantidade de encaminhamentos para especialidades que requerem acompanhamento terapêutico ou podem se desdobrar em procedimentos cirúrgicos, podendo sugerir o retorno dos usuários aos equipamentos de origem.

Os dados quantitativos relativos aos atendimentos na $A E$ denotam boa resolutividade, expressas pela baixa necessidade de consultas de retorno. Outra possibilidade apresentada é a inadequação do perfil dos usuários encaminhados, entretanto não é possível este esclarecimento.

A compreensão sobre a gestão do cuidado na rede de reabilitação foi possibilitada por apresentar as percepções de diferentes atores da rede, entretanto considera-se interessante a escuta dos gestores dos equipamentos de saúde e da gestão locorregional a fim de agregar as percepções de atores com maior penetrância no planejamento e na gestão da clínica e dos serviços de saúde. 


\section{REFERÊNCIAS BIBLIOGRÁFICAS}

Acioli S. Os sentidos das práticas voltadas para saúde e doença: maneiras de fazer de grupos da sociedade civil. In: Mattos RA, Pinheiro R. (orgs). Os sentidos da integralidade na atenção e no cuidado à saúde. Rio de Janeiro: Universidade do Estado do Rio de Janeiro, Instituto de Medicina Social e Associação Brasileira de Saúde Coletiva; 2006. p.161-70.

Almeida APSC, Nunes BP, Duro SMS, Facchini LA. Socioeconomic determinants of access to health services among older adults: a systematic review. Rev Saúde Pública. 2017;51,50:1-15.

Brasil. Ministério da Saúde. Portaria no 2.436, de 21 de setembro de 2017. Aprova a Política Nacional de Atenção Básica, estabelecendo a revisão de diretrizes para a organização da Atenção Básica, no âmbito do Sistema Único de Saúde (SUS). Brasília (DF): Ministério da Saúde, 2017. [Internet]. [Acesso em 2018 jan 13]. Disponível em:

http://bvsms.saude.gov.br/bvs/saudelegis/gm/2017/prt2436_22_09_2017.html

Brasil. Ministério da Saúde. Portaria no 4.279 de 30 de dezembro de 2010. Estabelece diretrizes para a organização da Rede de Atenção à Saúde no âmbito do Sistema Único de Saúde (SUS). Brasília (DF): Diário Oficial da União, 2010b.

Brasil. Ministério da Saúde. Portaria no 793, de 24 de abril de 2012. Institui a Rede de Cuidados à Pessoa com Deficiência no âmbito do Sistema Único de Saúde. Brasília (DF): Diário Oficial da União, 2012a.

Brasil. Ministério da Saúde. Portaria no 835 de 25 de abril de 2012. Institui incentivos financeiros de investimento e de custeio para o Componente Atenção Especializada da Rede de Cuidados à Pessoa com Deficiência no âmbito do Sistema Único de Saúde. Brasília (DF), 2012b. 
Brasil. Ministério da Saúde. Secretaria de Atenção à Saúde. Departamento de Ações Programáticas Estratégicas. Política Nacional de Saúde da Pessoa com Deficiência. Brasília (DF): Ministério da Saúde, 2010a.

Brasil. Ministério da Saúde. Secretaria de Atenção à Saúde. Departamento de Atenção Básica. Diretrizes para o cuidado das pessoas com doenças crônicas nas redes de atenção à saúde e nas linhas de cuidado prioritárias. Brasília (DF), 2013.

Brasil. Ministério do Planejamento, Orçamento e Gestão. Instituto Brasileiro de Geografia e Estatística. Diretoria de Pesquisas, Coordenação de Trabalho e Rendimento. Pesquisa Nacional por Amostra de Domicílios Contínua. Disponível em <http://www.ibge.gov.br/estadosat/perfil.php?lang=\&sigla=sp>. Acesso em: 20 de jan. 2016.

Campos MF, Souza LAP, Mendes VLF. A rede de cuidados do Sistema Único de Saúde à saúde das pessoas com deficiência. Interface (Botucatu). Mar 2015; 19,52:207-210.

Cavalcanti CTJ. Lógica médico-sanitária do senso comum: um estudo de representação social de profissionais e pacientes de uma Unidade Básica de Saúde em Campinas [tese]. São Paulo: Faculdade de Saúde Pública da Universidade de São Paulo; 2015.

Cecilio LCO. Apontamentos teórico-conceituais sobre processos avaliativos considerando as múltiplas dimensões da gestão do cuidado em saúde. Interface (Botucatu). Jun. 2011;15,37:589-599.

Coelho MO, Jorge MSB. Tecnologia das relações como dispositivo do atendimento humanizado na atenção básica à saúde na perspectiva do acesso, do acolhimento e do vínculo. Ciência \& Saúde Coletiva. 2009;14,1:1523-1531. 
Conill EM, Fausto MCR. Análisis de la problemática de la integración de la APS en el contexto actual: causas que inciden em la fragmentación de servicios y sus efectos em la cohesión social. Proyecto Eurosocial, Documento técnico. Rio de Janeiro: 2007.

Faro ACM. Reabilitação: ampliando os horizontes, legitimando o saber legitimando o saber. Rev Esc Enferm USP. 2006:40,1:128-33, 2006.

Feuerwerker LCM, Vertussi DC, Merhy EE (orgs.). Avaliação compartilhada do cuidado em saúde: surpreendendo o instituído nas redes. Rio de Janeiro: Hexis; 2016. v. 2:440 p.

Fortes PAC, Zoboli ELCP. Bioética e Promoção da Saúde. In: Lefèvre F, Lefèvre AMC. Promoção da Saúde - a negação da negação. Rio de Janeiro: Vieira e Lent; 2004. p.147-63.

Hajjioui A, Fourtassi M, Nejjari C. Prevalence of Disability and Rehabilitation Needs Amongst Adult Hospitalized Patients in a Moroccan University Hospital. J Rehabil Med. Ago. 2015;47,7:593-598.

Hino P, Ciosak SI, Fonseca RMG, Yoshikawa E. Necessidades em saúde e atenção básica: validação de instrumentos de captação. Rev. Esc. Enferm USP. Dec. 2009;43,2:1156-1167.

Le Breton, D. Antropologia do corpo e modernidade. Petrópolis: Vozes; 2012.

Lussi IAO, Pereira MAO, Junior AP. A proposta de reabilitação psicossocial de Saraceno: um modelo de auto-organização? Rev. Latino-Am. Enfermagem Ribeirão Preto. Jun 2006;14,3. 
Mendes EV. As redes de atenção à saúde. Ciência \& Saúde Coletiva. Ago. 2010; 15,5:2297-2305.

Merhy EE. Saúde: a cartografia do trabalho vivo. São Paulo: HUCITEC; 2006.

Merhy EE, Franco TB. O trabalho em saúde: Olhando e experienciando o SUS no cotidiano. São Paulo: HUCITEC; 2003.

Merhy EE, Gomes MPC, Silva E, Santos MFL, Cruz KT, Franco TB. Redes Vivas: multiplicidades girando as existências, sinais da rua. Implicações para a produção do cuidado e a produção do conhecimento em saúde. Revista Divulgação em Saúde para Debate. Out 2014;52:153-164.

Merhy EE, Onocko R (orgs.). Agir em Saúde, um desafio para o público. São Paulo: HUCITEC; 1997.

Mitre SM, Andrade EIG, Cotta RMM. O acolhimento e as transformações na práxis da reabilitação: um estudo dos Centros de Referência em Reabilitação da Rede do Sistema Único de Saúde em Belo Horizonte, MG, Brasil. Ciência \& Saúde Coletiva. 2013;18,7:1893-1902.

Oliveira RR, Elias PEM. Conceitos de regulação em saúde no Brasil. Rev Saúde Pública. 2012;46,3:571-576.

Organização Mundial da Saúde. Direção Geral da Saúde. Classificação internacional de funcionalidade, incapacidade e saúde. Lisboa: OMS; 2004.

Organização das Nações Unidas. Normas sobre a equiparação de oportunidade para pessoas com deficiência. São Paulo: APADE, CVI, NA; 2006.introdução

Ribeiro CTM, Ribeiro MG, Araújo AP, Mello LR, Rubim LC, Ferreira JES. O 
sistema público de saúde e as ações de reabilitação no Brasil. Rev Panam Salud Publica. 2010;28(1):43-8.

Rodes $\mathrm{CH}$, Kurebayashi R, Kondo VE, Luft VD, DE Góes AB, Schmitt ACB. O acesso e o fazer da reabilitação na Atenção Primária à Saúde. Rev Fisioter Pesqui. 2017;24,1:74-82.

São Paulo (município). Faculdade de Medicina da Universidade de São Paulo. Cultura e Extensão. Projeto Região Oeste. Disponível em http://ccex.fm.usp.br/portal/extensão/. Acesso em 06 de jan.2018b.

São Paulo (município). Hospital universitário da Universidade de São Paulo, Campus da Capital. História do Hospital Universitário. Disponível em <http://www.hu.usp.br/historia/>. Acesso em 06 de jan. 2018a.

São Paulo (município). Prefeitura da Universidade de São Paulo, Campus da Capital. História da Cidade Universitária "Armando de Salles Oliveira" (CUASO). Disponível em <http:// http://www.puspc.usp.br/institucional/historia-da-cuaso/>. Acesso em 27 de mai. 2017.

São Paulo (município). Secretaria Municipal da Saúde. População recenseada, taxas de crescimento populacional e densidade demográfica município de São Paulo, subprefeituras e distritos municipais. Disponível em <http://infocidade.prefeitura.sp.gov.br/htmls/7_populacao_recenseadataxas_de_cr es cimento_1980_10745.html>. Acesso em: 20 de jan. 2016b.

São Paulo (município). Secretaria de Estado da Saúde. População SEADE - 2013 a 2015. População total segundo município. Período: 2015. Disponível em <http://www.saude.sp.gov.br/links/matriz>. Acesso em: 26 de jan. 2016a.

São Paulo (município). Secretaria Municipal da Saúde. Relação dos 
estabelecimentos/serviços da secretaria municipal da saúde por coordenadoria regional de saúde e supervisão técnica de saúde do município de São Paulo. Disponível em <http://www.prefeitura.sp.gov.br/cidade/secretarias/upload/saude/arquivos/organiz ac ao/Unid_Munic_Saude_Super.pdf>. Acesso em 19 jan. 2015.

Travassos C, Martins M. Uma revisão sobre os conceitos de acesso e utilização de serviços de saúde. Cad. Saúde Pública. 2004;20(Suppl 2):S190-S198.

Travassos C, Oliveira EXG, Viacava F. Desigualdades geográficas e sociais no acesso aos serviços de saúde no Brasil: 1998 e 2003. Ciência \& Saúde Coletiva. 2006;11,4:975-986.

Travassos C, Viacava F, Fernandes C, Almeida CM. Desigualdades geográficas e sociais na utilização de serviços de saúde no Brasil. Ciência \& Saúde Coletiva. 2000;5,1:133-149.

Uchoa AC, Vieira RMV, Rocha PM, Rocha NSD, Maroto RM. Trabalho em equipe no contexto da reabilitação infantil. Physis Revista de Saúde Coletiva, 2012;22,1:385-400. 


\title{
8. ANEXOS
}

\subsection{Apêndice 1: Autorizações para a realização da pesquisa.}

\section{CEP da Faculdade de Medicina da Universidade de São Paulo}

\author{
FACULDADE DE MEDICINA DA \\ UNIVERSIDADE DE SÃO \\ PAULO - FMUSP
}

\section{PARECER CONSUBSTANCIADO DO CEP}

\section{DADOS DO PROJETO DE PESQUISA}

Título da Pesquisa: Rede viva: a realidade da Rede de Atenção à Reabilitação no Estado de São Paulo.

Pesquisador: Ana Carolina Basso Schmitt

Área Temática:

Versão: 1

CAAE: 58422516.5 .1001 .0065

Instituição Proponente: Faculdade de Medicina da Universidade de São Paulo

Patrocinador Principal: Financiamento Próprio

DADOS DO PARECER

Número do Parecer: 1.754 .917

\section{Apresentação do Projeto:}

Trata-se de projeto de pesquisa multicêntrico com objetivos acadêmicos de Mestrado do Programa de Ciências da Reabilitação.

O projeto está bem elaborado, com vários co-participantes, a saber. projeto de integração pesquisa $\mathrm{e}$ serviço que engloba a Universidade de São Paulo (USP) e Universidade Federal de São Carlos (UFSCAR) com representação de dois Departamentos Regionais de Saúde do Estado de São Paulo: I - Grande São Paulo com a

Coordenadoria Regional de Saúde Oeste e III - Araraquara com a cidade de São Carlos, respectivamente Os co participantes afirmam que concordam com o estudo em seus equipamentos, desde que seja aprovado pelo CEP

Objetivo da Pesquisa:

Compreender a gestão do cuidado de reabilitação em dois Departamentos Regionais de Saúde do Estado de São Paulo: I- Grande São Paulo com a Coordenadoria Regional de Saúde Oeste e III-Araraquara com a cidade de São Carlos.

O estudo pretende ainda analisar os acessos à rede de atenção à reabilitação e descrever as ações e atividades relacionadas à reabilitação nos equipamentos de saúde da rede em questão;identificar $e$ analisar os fluxos internos dos equipamentos de saúde, relacionados à reabilitação;identificar $\mathrm{e}$

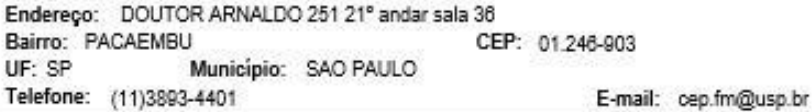



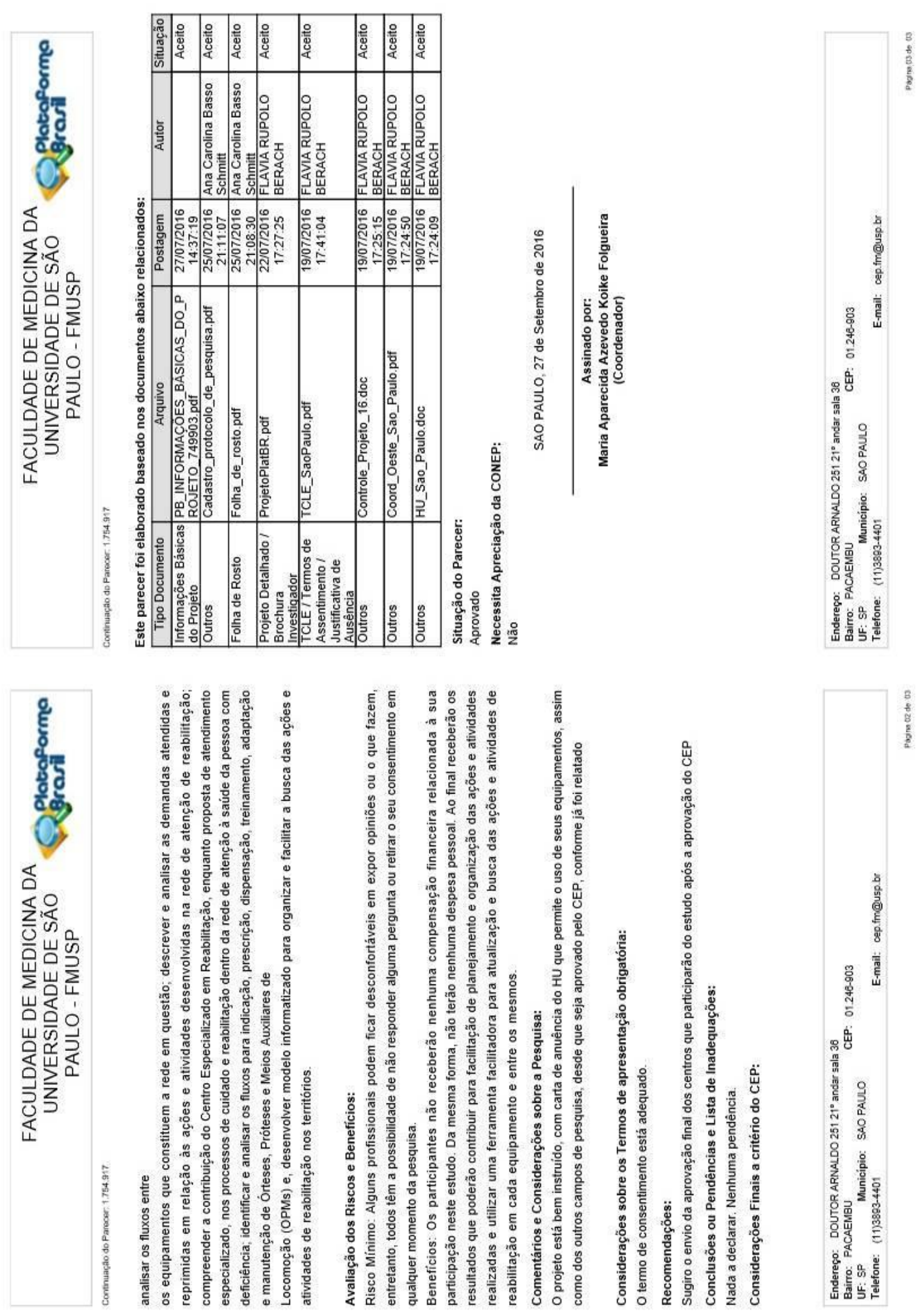


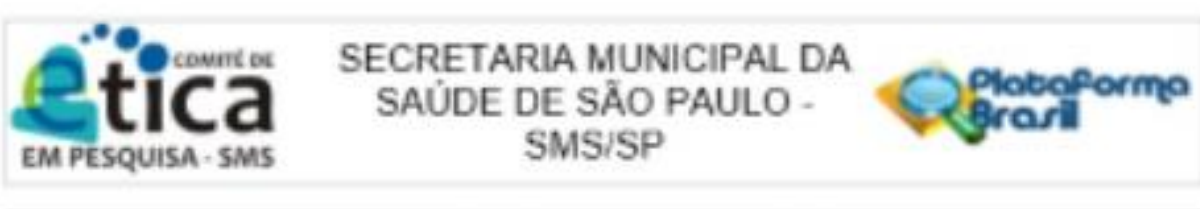

PARECER CONSUBSTANCIADO DO CEP

Elaborads peia Instatuig bo Coparticipante

\section{DADOS OO PGOJETO De PESOUISA}

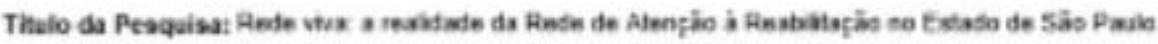

Pesquisador: Ans Cartina Banos Setrmt

Áres Temitica:

Versio: 1

CAMC: 50422515.5 .3001 .0006

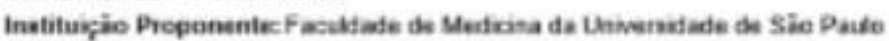

Patrocinador Princteat: Finansianenbe Prdpro

DADOS DO PAPECER

Nimero do Parecer: 1.000 .137

Acresentopilo do Projeto:

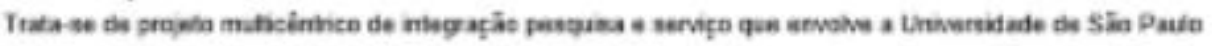

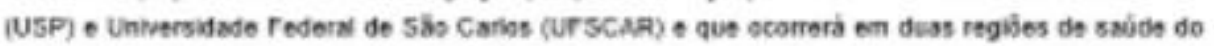
Estado de Sso Pauto: 1 - Grande Sae Paulo, Supervisbe Tecnica de Saúbe Butantz. Ceordenaboria

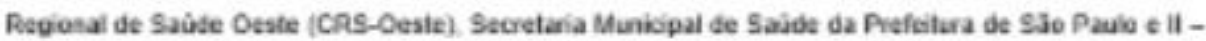

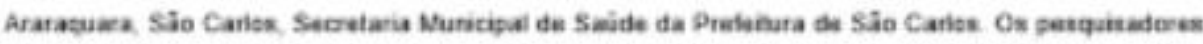

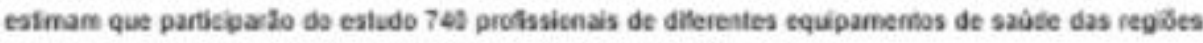

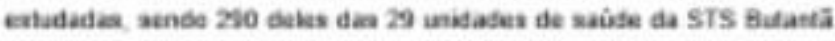

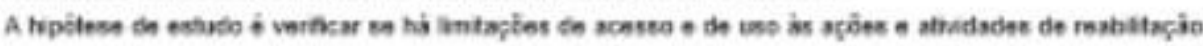

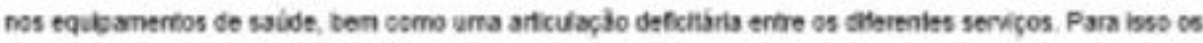
pesquisasores ardicularbo grpos de discussles con os profosionain das utidades, conforme roteito de

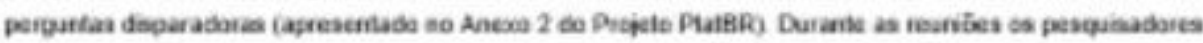

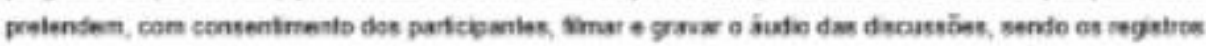
arquhados e protegidos per sesha, com acesso somerbe dos pesquisadores. pels periodo de 5 anss. Tamben havera consuta a repistros e cotunentos, tas come Fikhas de Registo Didris de Alvidades e Precedimentos te casta canegaria

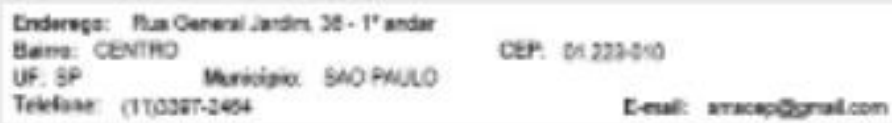




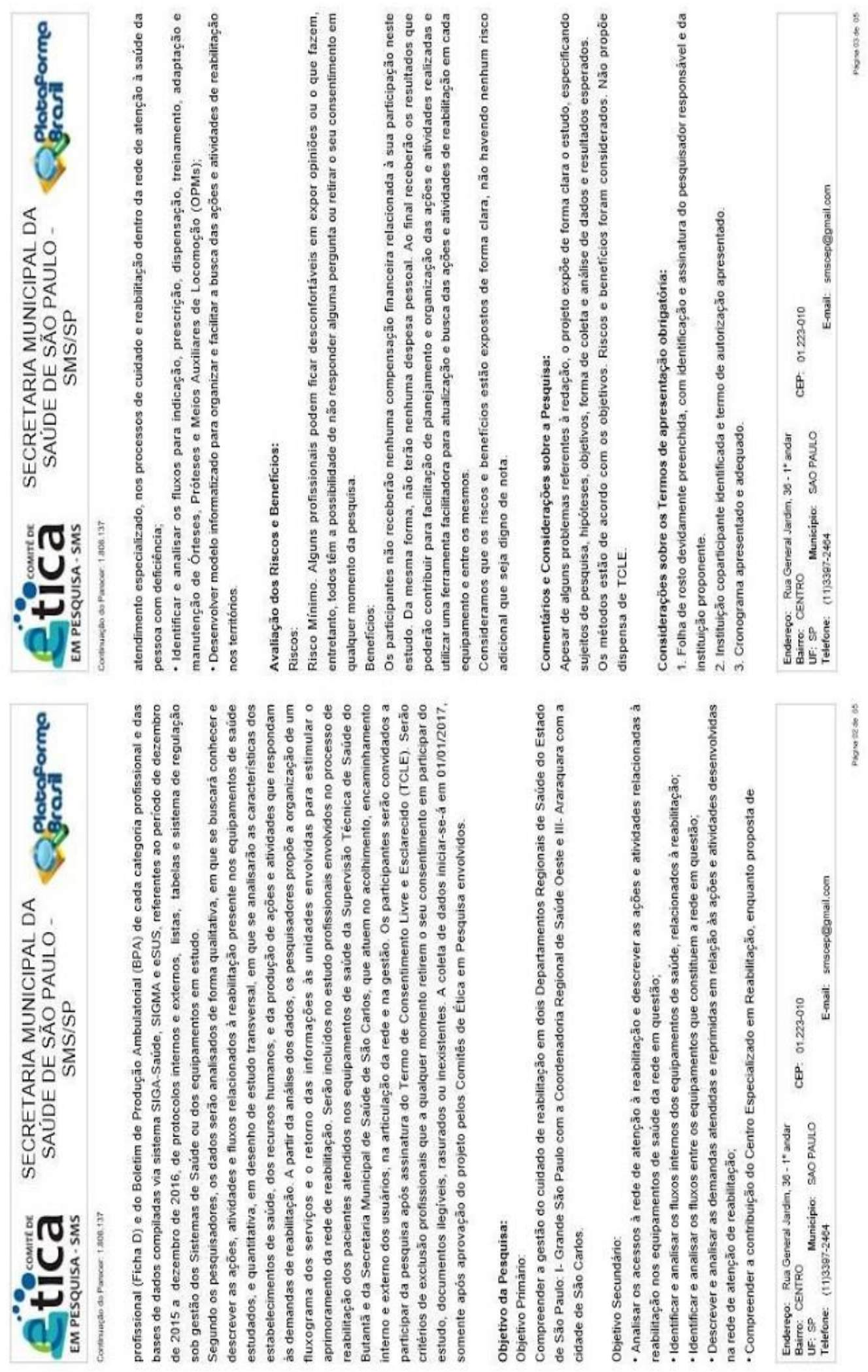



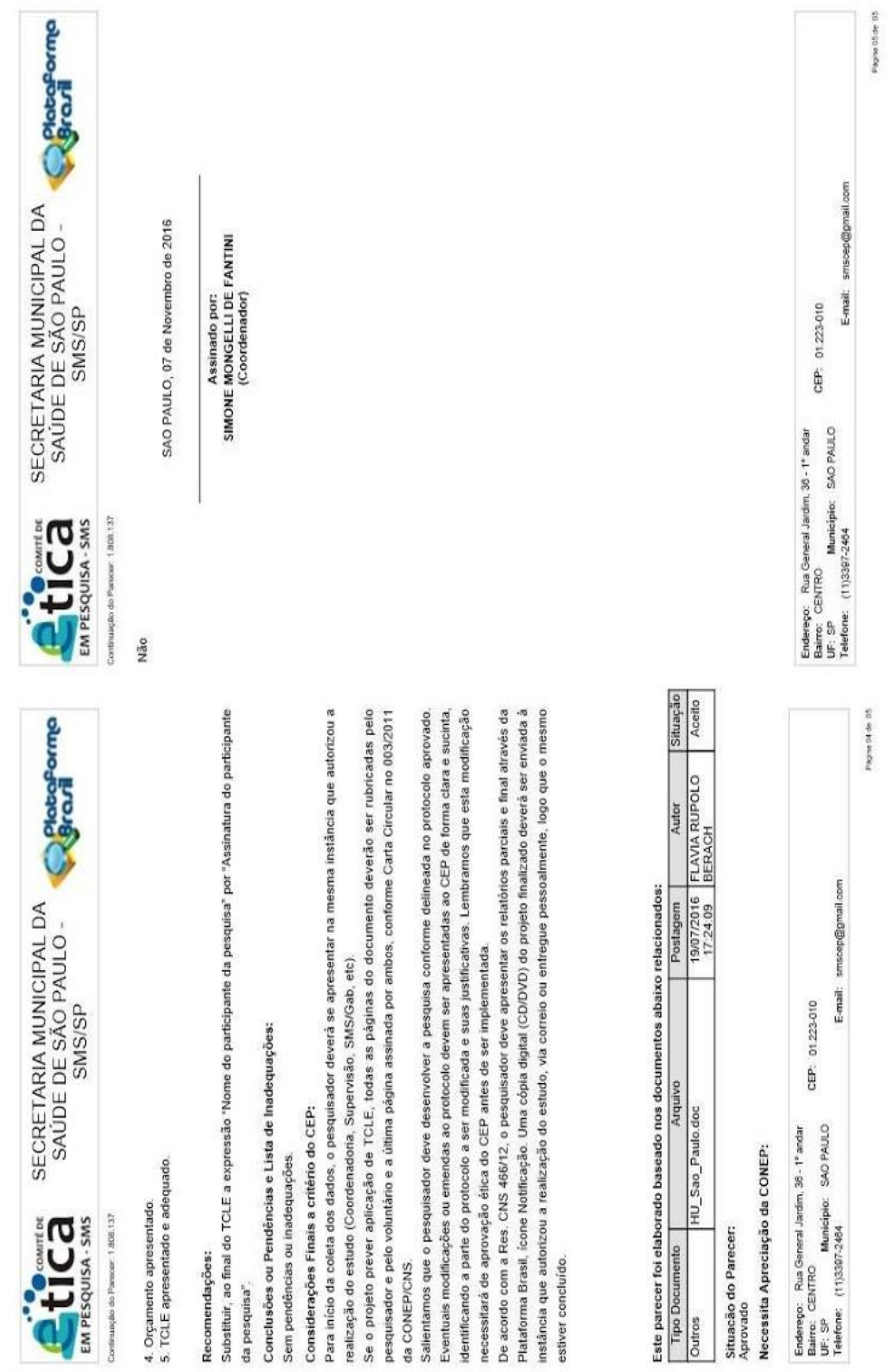
8.2 Apêndice 2 - Termo de Consentimento Livre e Esclarecido para os profissionais dos equipamentos de saúde

Universidade de São Paulo

$\frac{\text { MEDICINA }}{\text { TSP }}$

Faculdade de Medicina

Departamento de Fisioterapia, Fonoaudiologia e Terapia Ocupacional

Pós-graduação em Ciências da Reabilitação

TERMO DE CONSENTIMENTO LIVRE E ESCLARECIDO (TCLE)

\section{DADOS DE IDENTIFICAÇÃO DO SUJEITO DA PESQUISA OU RESPONSÁVEL LEGAL}

1. NOME:

DOCUMENTO DE IDENTIDADE No.

SEXO : $M \quad F$

DATA NASCIMENTO:

ENDEREÇO

No

APTO:

BAIRRO: CIDADE

CEP.

TELEFONE: DDD (

2. RESPONSÁVEL LEGAL:

NATUREZA (grau de parentesco, tutor, curador etc.)

DOCUMENTO DE IDENTIDADE No.

SEXO : $M \quad F$

DATA NASCIMENTO:

ENDEREÇO

No

APTO:

BAIRRO: CIDADE

CEP: TELEFONE: DDD ( .) 


\section{DADOS SOBRE A PESQUISA}

1. TÍTULO DO PROTOCOLO DE PESQUISA: Rede viva: a realidade da Rede de Atenção à Reabilitação no Estado de São Paulo.

2. PESQUISADOR: Ana Carolina Basso Schmitt

CARGO/FUNÇÃO: Professora do Departamento de Fonoaudiologia, Fisioterapia e Terapia Ocupacional da Faculdade de Medicina da Universidade de São Paulo INSCRIÇÃO CONSELHO REGIONAL: CREFITO 3 - 29994F

UNIDADE DO HCFMUSP: Departamento de Fonoaudiologia, Fisioterapia e Terapia Ocupacional da Faculdade de Medicina da Universidade de São Paulo 3. AVALIAÇÃO DO RISCO DA PESQUISA: O risco desta pesquisa é mínimo devido aos possíveis desconfortos do participante em expor informações relacionadas ao seu trabalho perante ao grupo. Vale ressaltar que os participantes terão a total liberdade de retirar o seu consentimento e deixar de participar do estudo a qualquer momento, sem prejuízo.

4. DURAÇÃO DA PESQUISA: 2 anos.

\section{TERMO DE CONSENTIMENTO LIVRE E ESCLARECIDO (TCLE)}

A presente pesquisa, intitulada Rede Viva: a realidade da Rede de Atenção à Reabilitação no Estado de São Paulo tem como objetivo geral compreender a gestão do cuidado de reabilitação do território da Supervisão Técnica de Saúde do Butantã da Coordenadoria Regional de Saúde Oeste do município de São Paulo. Dentre os objetivos específicos temos: analisar os acessos à rede de atenção à reabilitação; descrever as ações e atividades relacionadas à reabilitação nos equipamentos de saúde da rede em questão, segundo os profissionais que atuam no processo de reabilitação nos equipamentos; identificar e analisar os fluxos internos relatados pelos profissionais dos equipamentos de saúde, relacionados à reabilitação; identificar e analisar os fluxos de referência e contrarreferência entre os equipamentos que constituem a rede em questão, relatados pelos profissionais dos equipamentos; e descrever e analisar as demandas atendidas e reprimidas 
em relação às ações e atividades desenvolvidas na rede de atenção de reabilitação.

A pesquisadora Flávia Rúpolo Berach realizará o estudo como Projeto de Mestrado do Programa de Pós-graduação em Ciências da Reabilitação, orientada pela Profa Dra Ana Carolina Basso Schmitt, docente do Departamento de Fisioterapia, Fonoaudiologia e Terapia Ocupacional da Faculdade de Medicina da Universidade de São Paulo.

Convidamos você a participar desta pesquisa. A coleta de dados será feita a partir de uma conversa em grupo, no qual será realizada uma discussão entre os profissionais envolvidos no atendimento dos usuários. Posteriormente será realizado um novo encontro para devolutiva e validação das informações coletadas e classificação dos fluxos conforme sua relevância. Solicitamos sua autorização para registrar em vídeo estes momentos a fim de auxiliar na análise dos dados. Estes registros serão armazenados em computador próprio para o projeto com senha e restrição de uso (apenas entre os pesquisadores) e após cinco anos serão deletados.

Todas as informações obtidas a seu respeito neste estudo serão analisadas em conjunto com as de outros voluntários, não sendo divulgado a sua identificação ou de outros participantes em nenhum momento. Você tem a garantia de que todos os dados obtidos a seu respeito, assim como qualquer material coletado só serão utilizados neste estudo. Caso deseje, você terá a total liberdade de retirar o seu consentimento e deixar de participar do estudo a qualquer momento, sem prejuízo algum.

Você não receberá nenhuma compensação financeira relacionada à sua participação neste estudo. Da mesma forma, você não terá nenhuma despesa pessoal. Vale ressaltar que o risco de participar desta pesquisa é mínimo.

A qualquer momento, se for de seu interesse, você poderá ter acesso a todas as informações obtidas a seu respeito neste estudo ou a respeito dos resultados gerais do estudo. Quando o estudo for finalizado, você será informado sobre os principais resultados e conclusões obtidas no estudo.

Em qualquer etapa do estudo, você terá acesso aos profissionais 
responsáveis pela pesquisa para esclarecimento de eventuais dúvidas. As pesquisadoras Ana Carolina Basso Schmitt e Flávia Rúpolo Berach podem ser encontradas no endereço Rua Cipotânea, 51, Cidade Universitária - São Paulo (SP), CEP: 05360-000, telefone: 11 3091-8421. Se você tiver alguma consideração ou dúvida sobre a ética da pesquisa, entre em contato com o Comitê de Ética em Pesquisa da Faculdade de Medicina da Universidade de São Paulo (CEP-FMUSP), localizado na Av. Dr. Arnaldo, 251, 210 andar, sala 36, Cerqueira César - São Paulo (SP), CEP: 01246-000, telefone: 3893-4401 ou 3893-4407, email: cep.fm@usp.br ou com o Comitê de Ética em Pesquisas da Secretaria Municipal da Saúde de São Paulo, localizado na Rua General Jardim, 36, 10 andar, República - São Paulo (SP), CEP.: 01223-011, telefone: 3397-2464, e-mail: smscep@gmail.com.

Esse termo foi elaborado em duas vias devidamente assinadas e rubricadas pela pesquisadora e por você, participante. Uma via ficará com você e a outra com a pesquisadora.

"Acredito ter sido suficientemente informado a respeito das informações que li ou que foram lidas para mim, descrevendo o "Rede Viva: a realidade da Rede de Atenção à Reabilitação no Estado de São Paulo" Eu discuti com Ana Carolina Basso Schmitt e Flávia Rúpolo Berach sobre a minha decisão em participar nesse estudo. Ficaram claros para mim quais são os propósitos do estudo, os riscos, as garantias de confidencialidade e de esclarecimentos permanentes. Ficou claro também que minha participação é isenta de despesas. Concordo voluntariamente em participar deste estudo e poderei retirar 0 meu consentimento a qualquer momento, antes ou durante $o$ mesmo, sem prejuízos. "

Data:

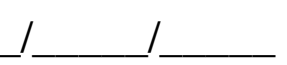


Nome do participante da pesquisa

\begin{abstract}
Assinatura
Declaro que obtive de forma apropriada e voluntária, o Consentimento Livre e Esclarecido deste participante para a participação neste estudo.
\end{abstract}

Data:

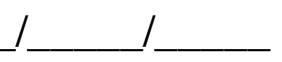

Ana Carolina Basso Schmitt Responsável pelo estudo

Assinatura 
8.3 Apêndice 3 - Roteiro para facilitação dos Grupos de Discussão

\section{Momento 1}

1. Qual a experiência de vocês no trabalho com reabilitação neste equipamento/serviço?

2. Quanto ao acesso ao equipamento e fluxos internos - Como é a experiência de vocês na organização dos fluxos internos de encaminhamento dos usuários/pacientes que apresentam demandas de reabilitação?

Possíveis desdobramentos:

- De onde vêm os usuários que procuram o equipamento de saúde que vocês trabalham? (Locais/equipamentos)

- Quais são as necessidades de saúde relacionadas à reabilitação dos usuários que chegam até vocês? Quais são as demandas de saúde relacionadas à reabilitação que são percebidas pela equipe?

- Vocês identificam pessoas que necessitam de OPM? Se sim o que vocês fazem?

- Quais as ações / atividades relacionadas a reabilitação que vocês fazem neste equipamento?

- Qual é o fluxo de encaminhamentos que vocês fazem dentro deste equipamento de saúde?

- Existe algum fluxo de encaminhamento já estabelecido dentro deste equipamento? Existe alguma forma de registro?

- Os encaminhamentos que vocês fazem dentro deste equipamento funcionam? 


\section{Momento 2}

3. Quanto aos fluxos externos e articulação com a rede - Como é a experiência de vocês na articulação com outros equipamentos/serviços para atender às demandas de reabilitação dos usuários/pacientes?

Possíveis desdobramentos:

- Para onde vocês encaminham os usuários que não têm suas necessidades de saúde relacionadas à reabilitação atendidas aqui?

- Quais outros equipamentos da rede de atenção com os quais vocês se articulam?

- Existe algum fluxo de encaminhamento relacionado à reabilitação já estabelecido entre os equipamentos nesta região?

- Existe algum registro/comunicação (contrarreferência) com os outros equipamentos sobre os usuários recebidos, encaminhados, reencaminhados ou que estão em atendimento?

- Usuários com quais demandas ou necessidades vocês encaminham para lá?

- Vocês realizam ações / atividades relacionadas à reabilitação junto a algum equipamento desta região?

- Como é o trabalho da rede de atenção à reabilitação desta região?

- Os encaminhamentos que vocês fazem para outros equipamentos funcionam? 
8.4 Apêndice 4 - Termo de Consentimento Livre e Esclarecido para os usuários dos equipamentos de saúde

Universidade de São Paulo

Faculdade de Medicina

Departamento de Fisioterapia, Fonoaudiologia e Terapia Ocupacional

Pós-graduação em Ciências da Reabilitação

\section{DADOS DE IDENTIFICAÇÃO DO SUJEITO DA PESQUISA OU RESPONSÁVEL LEGAL}

1. NOME:

DOCUMENTO DE IDENTIDADE No.

SEXO: $M$

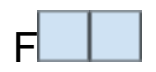

DATA NASCIMENTO:

ENDEREÇO No APTO:

BAIRRO: CIDADE CEP: TELEFONE: DDD .) $\frac{\overline{\text { MEDICINA }}}{\text { TSP }}$ . 


\section{DADOS SOBRE A PESQUISA}

1. TÍTULO DO PROTOCOLO DE PESQUISA: Rede viva: a realidade da Rede de Atenção à Reabilitação no Estado de São Paulo

2. PESQUISADOR: Ana Carolina Basso Schmitt

CARGO/FUNÇÃO: Professora do Departamento de Fonoaudiologia, Fisioterapia e Terapia Ocupacional da Faculdade de Medicina da Universidade de São Paulo INSCRIÇÃO CONSELHO REGIONAL: CREFITO 3 29994F

UNIDADE DO HCFMUSP: Departamento de Fonoaudiologia, Fisioterapia e Terapia Ocupacional da Faculdade de Medicina da Universidade de São Paulo 3. AVALIAÇÃO DO RISCO DA PESQUISA: O risco desta pesquisa é mínimo devido aos possíveis desconfortos do participante em expor informações relacionadas ao seu trabalho perante ao grupo. Vale ressaltar que os participantes terão a total liberdade de retirar o seu consentimento e deixar de participar do estudo a qualquer momento, sem prejuízo.

4. DURAÇÃO DA PESQUISA: 2 anos.

\section{TERMO DE CONSENTIMENTO LIVRE E ESCLARECIDO (TCLE)}

A presente pesquisa, intitulada Rede viva: a realidade da Rede de Atenção à Reabilitação no Estado de São Paulo tem como objetivos compreender a gestão do cuidado de reabilitação do território da Supervisão Técnica de Saúde do Butantã da Coordenadoria Regional de Saúde Oeste do município de São Paulo; descrever as ações e atividades relacionadas à reabilitação nos equipamentos de saúde da rede em questão; identificar e analisar os fluxos de dentro e entre os equipamentos de saúde, relacionados à reabilitação.

A pesquisadora Flávia Rúpolo Berach realizará o estudo como Projeto de Mestrado do Programa de Pós-graduação em Ciências da Reabilitação, orientada pela Profa Dra Ana Carolina Basso Schmitt, docente do Departamento de Fisioterapia, Fonoaudiologia e Terapia Ocupacional da Faculdade de Medicina da Universidade de São Paulo. 
Convidamos você a participar desta pesquisa. A coleta de dados será feita a partir de uma conversa individual sobre as suas questões de saúde e como os serviços da região se organizam para atendê-los. As informações fornecidas serão armazenadas em computador próprio para o projeto com senha e restrição de uso (apenas entre os pesquisadores) e após cinco anos serão deletadas.

Todas as informações obtidas a seu respeito neste estudo serão analisadas em conjunto com as de outros voluntários, não sendo divulgado a sua identificação ou de outros participantes em nenhum momento. Você tem a garantia de que todos os dados obtidos a seu respeito, assim como qualquer material coletado só serão utilizados neste estudo. Caso deseje, você terá a total liberdade de retirar o seu consentimento e deixar de participar do estudo a qualquer momento, sem prejuízo algum.

Você não receberá nenhuma recompensa relacionada à sua participação neste estudo. Da mesma forma, você não terá nenhuma despesa. Vale ressaltar que o risco de participar desta pesquisa é mínimo.

A qualquer momento, se for de seu interesse, você poderá ter acesso a todas as informações obtidas a seu respeito neste estudo ou a respeito dos resultados gerais do estudo. Quando o estudo for finalizado, você será informado sobre os principais resultados e conclusões obtidas no estudo.

Em qualquer etapa do estudo, você terá acesso aos profissionais responsáveis pela pesquisa para esclarecimento de eventuais dúvidas. As pesquisadoras Ana Carolina Basso Schmitt e Flávia Rúpolo Berach podem ser encontradas no endereço Rua Cipotânea, 51, Cidade Universitária - São Paulo (SP), CEP: 05360000, telefone: 11 30918421. Se você tiver alguma consideração ou dúvida sobre a ética da pesquisa, entre em contato com o Comitê de Ética em Pesquisa da Faculdade de Medicina da Universidade de São Paulo (CEPFMUSP), localizado na Av. Dr. Arnaldo, 251, 210 andar, sala 36, Cerqueira César São Paulo (SP), CEP: 01246000, telefone: 38934401 ou 38934407, e-mail: cep.fm@usp.br ou com o Comitê de Ética em Pesquisas da Secretaria Municipal da Saúde de São Paulo, localizado na Rua General Jardim, 36, 10 andar, 
República São Paulo (SP), CEP.: 01223011, telefone: 33972464, e-mail: smscep@gmail.com.

Esse termo foi elaborado em duas vias devidamente assinadas e rubricadas pela pesquisadora e por você, participante. Uma via ficará com você e a outra com a pesquisadora.

"Acredito ter sido suficientemente informado a respeito das informações que li ou que foram lidas para mim, descrevendo o estudo "Rede viva: a realidade da Rede de Atenção à Reabilitação no Estado de São Paulo". Eu discuti com Ana Carolina Basso Schmitt e Flávia Rúpolo Berach sobre a minha decisão em participar nesse estudo. Ficaram claros para mim quais são os propósitos do estudo, os riscos, as garantias de confidencialidade e de esclarecimentos permanentes. Ficou claro também que minha participação é isenta de despesas. Concordo voluntariamente em participar deste estudo e poderei retirar 0 meu consentimento a qualquer momento, antes ou durante $o$ mesmo, sem prejuízos. "

Data: 1

Nome do participante da pesquisa

Assinatura

Declaro que obtive de forma apropriada e voluntária, o Consentimento Livre e Esclarecido deste participante para a participação neste estudo.

Data:

Ana Carolina Basso Schmitt 
Responsável pelo estudo

Assinatura 


\subsection{Apêndice 5-Dados coletados no sistema E-SUS}

Equipamentos de saúde, por nível de Atenção: Atenção Primária à Saúde; Atenção Especializada; Atenção Hospitalar e da Urgência e Emergência.

Idade do usuário em anos, a partir da data de nascimento.

Especialidade de encaminhamento: Acupuntura; Avaliador de Órteses; Próteses e Meios auxiliares de locomoção - Ortopédica; Especialista em Reabilitação Física; Fisiatria; Fisioterapia; Fonoaudiologia; Fonoaudiologia - Audiologia; Genética Clínica; Geriatria; Hansenologia; Neurocirurgia; Neurologia; Odontologia - Atendimento a pacientes com necessidades especiais; Ortopedia; Pneumologia; Psicologia; Psiquiatria; Reumatologia; Serviço Social; Técnico de Órtese e Prótese; Terapia Ocupacional.

Procedimento solicitado: Avaliação; Consulta; Exame; Órteses, Próteses e Meios Auxiliares de Locomoção (OPM).

Tipo de atendimento: Primeira vez; Retorno; Reserva Técnica.

Data de inclusão na fila de espera: dia/mês/ano.

Data de saída da fila de espera: dia/mês/ano.

Prioridade: Alta; Média; Baixa.

Capítulo da Classificação Estatística Internacional de Doenças e Problemas Relacionados com a Saúde - décima edição (CID-10): Capítulo I Algumas doenças infecciosas e parasitárias (A00-B99); Capítulo II Neoplasias [tumores] (C00-D48); Capítulo III Doenças do sangue e dos órgãos hematopoéticos e alguns transtornos imunitários (D50-D89); Capítulo IV Doenças endócrinas, nutricionais e metabólicas (E00-E90); Capítulo V Transtornos mentais e comportamentais (F00-F99); Capítulo VI Doenças do sistema nervoso (G00-G99); Capítulo VIII Doenças do ouvido e da apófise 
mastoide (H60-H95); Capítulo IX Doenças do aparelho circulatório (I00-199); Capítulo X Doenças do aparelho respiratório (J00-J99); Capítulo XII Doenças da pele e do tecido subcutâneo (L00-L99); Capítulo XIII Doenças do sistema osteomuscular e do tecido conjuntivo (M00-M99); Capítulo XIV Doenças do aparelho geniturinário (N00N99); Capítulo XV Gravidez, parto e puerpério (O00-O99); Capítulo XVI Algumas afecções originadas no período perinatal (P00-P96); Capítulo XVII Malformações congênitas, deformidades e anomalias cromossômicas (Q00-Q99); Capítulo XIX Lesões, envenenamento e algumas outras consequências de causas externas (S00T98); Capítulo XX Causas externas de morbidade e de mortalidade (V01-Y98); Capítulo XXI Fatores que influenciam o estado de saúde e o contato com os serviços de saúde (Z00-Z99).

Status na fila de espera: Ativo; Inativo. 